\title{
Canada: 2009 Article IV Consultation-Staff Report; Staff Statement; and Public Information Notice on the Executive Board Discussion
}

Under Article IV of the IMF's Articles of Agreement, the IMF holds bilateral discussions with members, usually every year. In the context of the 2009 Article IV consultation with Canada, the following documents have been released and are included in this package:

- The staff report for the 2009 Article IV consultation, prepared by a staff team of the IMF, following discussions that ended on March 9, 2009, with the officials of Canada on economic developments and policies. Based on information available at the time of these discussions, the staff report was completed on April 17, 2009. The views expressed in the staff report are those of the staff team and do not necessarily reflect the views of the Executive Board of the IMF.

- A staff statement of May 11, 2009, updating information on recent developments.

- $\quad$ A Public Information Notice (PIN) summarizing the views of the Executive Board as expressed during its May 11, 2009 discussion of the staff report that concluded the Article IV consultation.

The document listed below has been or will be separately released.

\section{Selected Issues Paper}

The policy of publication of staff reports and other documents allows for the deletion of market-sensitive information.

\author{
Copies of this report are available to the public from \\ International Monetary Fund • Publication Services \\ $70019^{\text {th }}$ Street, N.W. • Washington, D.C. 20431 \\ Telephone: (202) 623-7430 • Telefax: (202) 623-7201 \\ E-mail: publications@imf.org•Internet: http://www.imf.org
}

\section{International Monetary Fund Washington, D.C.}



INTERNATIONAL MONETARY FUND

CANADA

\title{
Staff Report for the 2009 Article IV Consultation
}

\author{
Prepared by Western Hemisphere Department \\ (In consultation with other departments)
}

Approved by David J. Robinson and Tamim Bayoumi

April 17, 2009

\section{EXECUTIVE SUMMARY}

- $\quad$ Focus. The mission focused on measures to manage the risks and vulnerabilities arising from the global financial crisis, slowing world growth, and collapsing commodity prices.

- Background. Canada entered the financial crisis on a solid footing, reflecting a strong macroeconomic framework, rigorous financial regulation, and robust corporate balance sheets. While it has avoided severe spillovers, international linkages are pressuring financial conditions and economic growth.

- Economic outlook. Policy stimulus will lessen the downturn, although growth will likely contract in 2009 before rebounding modestly in 2010. A widening output gap will push core inflation to low levels. Uncertainties about global growth and international financial stability tilt risks to the downside.

- $\quad$ Financial sector. Canadian banks have weathered the crisis better than major-country peers, but the credit cycle will be challenging, particularly given high household debt. Financial instability is a tail risk, but heightened vigilance is warranted.

- Monetary policy. The Bank of Canada has appropriately loosened monetary policy, bringing the policy rate target to a record-low $1 / 2$ percent. Maintaining an accommodative stance until economic recovery is firmly underway would ward off deflation risks.

- $\quad$ Fiscal policy. The recession and recent fiscal stimulus will end an 11-year string of surpluses. The 2009 Budget, along with provincial measures and the effects of past steps, includes total measures of about 2 percent of GDP per year over 2009-2010, adequate in present circumstances. Fiscal room is available to enact further stimulus if downside risks materialize. To maintain confidence in medium-term fiscal sustainability, the government can stress the aim to pursue its debt reduction targets when recovery begins.

- Analytical work. Background studies examine the reasons for Canada's comparative financial stability; linkages between financial conditions and growth; the role of commodity prices in the duration of economic slumps in commodity exporters; regional house-price dynamics; and the Canadian mortgage market. 
I. Macroeconomic and Financial Prospects and Risks 3

A. Entering the Global Crisis from a Position of Strength .......................................

B. Financial Stability Amid the Turbulence ......................................................

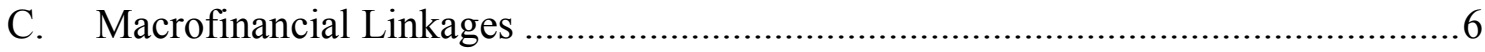

D. Outlook and Risks................................................................................. 7

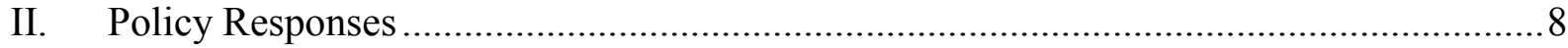

A. Monetary Policy: Warding Off Deflation Risks ........................................... 9

B. Safeguarding Financial Stability to Underpin Growth .................................... 10

C. Fiscal Actions Within a Strong Framework................................................ 12

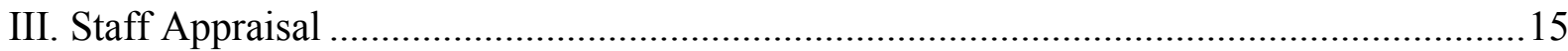

Boxes

1. Canadian Bank Regulatory Capital Requirements: Are they Tougher? ....................... 17

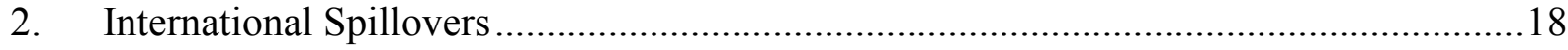

3. Exchange Rate Assessment............................................................................... 19

4. Canadian Bank Losses: Implications from FSSA Stress Tests...................................21

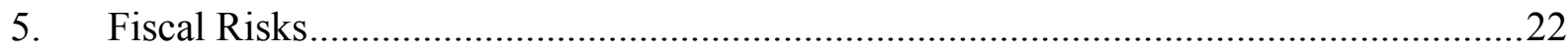

Figures

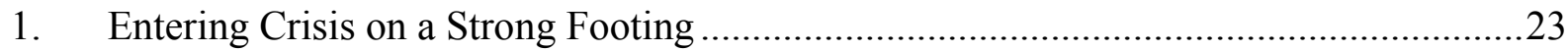

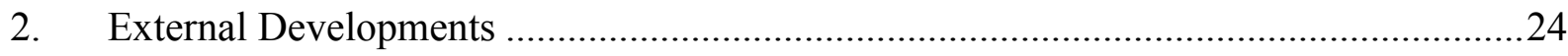

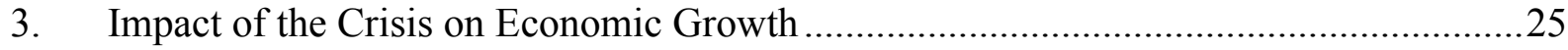

4. Strains in the Financial Market.................................................................................26

5. Resilience of the Banking Sector So Far ............................................................27

6. Impact of the Crisis on Non-Bank Financial Sector...............................................28

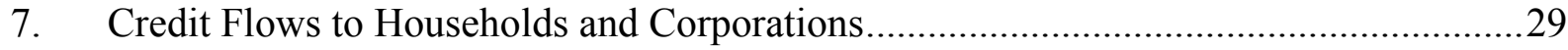

8. Risks to Households from Declining Income Growth ................................................30

9. Risks to Households from a Softening Housing Market .............................................. 31

10. The Impact of the Crisis on the Corporate Sector ................................................32

Tables

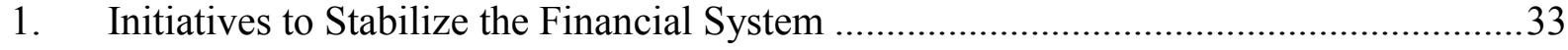

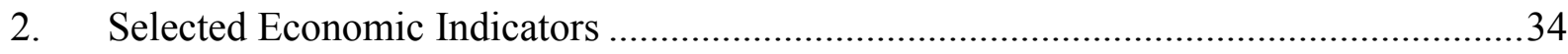

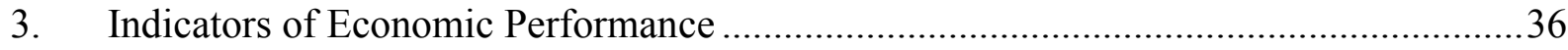

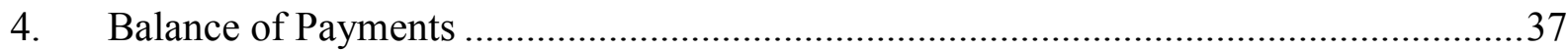

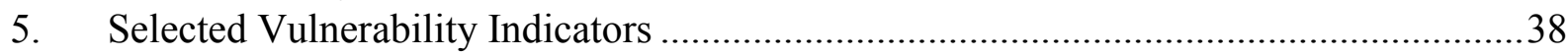

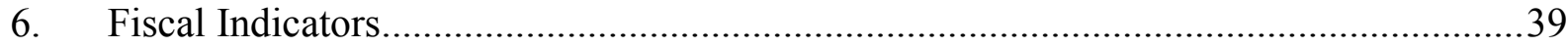




\section{Macroeconomic And Financial Prospects ANd Risks}

Despite Canada's close real and financial linkages to the United States, it has so far avoided the virulent spillovers seen elsewhere, as it entered the crisis on a strong footing. This reflects sound financial regulation and conservative banking practices, fiscal prudence, and a credible and effective monetary policy framework, including a freely-floating currency. Nevertheless, strains are evident, and the authorities are appropriately responding with stimulus and steps to support financial stability. With the global outlook marked by unusually high uncertainty, the main task for policymakers is to maintain continued vigilance and readiness to respond if tail risks are realized.

\section{A. Entering the Global Crisis from a Position of Strength}

1. Canada entered the global financial turmoil on a solid footing (Figure 1). Through 2007, sound macroeconomic and financial policies along with a commodity boom delivered strong growth, price stability, fiscal and current account surpluses (Figure 2), historically low unemployment, and financial stability. Corporate and bank leverage were low, although high household debt and regional real-estate bubbles presented vulnerabilities.

2. Nevertheless, the crisis has impacted growth and financial conditions. Canada is an open economy with strong real and financial linkages with the global economy, especially the United States, which accounts for about three-quarters of Canada's exports and around a quarter of funding for Canadian businesses. These links have affected Canada in several ways:

- $\quad$ Economic slowdown. Contracting external demand has depressed real exports; the wealth effects of falling equity, commodity, and house prices, along with financial tightening, have dampened domestic demand (Figure 3). Real GDP contracted by 3.4 percent (saar) in the fourth quarter of 2008 after a weak performance earlier in the year, and indicators point to a much deeper contraction in early 2009. Headline inflation has fallen sharply, due in part to collapsing oil prices.

- $\quad$ Financial market volatility. The global financial crisis sparked volatility and pushed credit and money-market spreads to unprecedented highs (Figure 4), although spreads are below foreign levels. Similarly, bank risk indicators have risen but are below comparable levels abroad (Figure 5). ${ }^{1}$ Meanwhile, pensions and insurers have been hit by U.S. mortgagerelated writedowns and the equity crash (Figure 6).

- $\quad$ Plunging commodity prices. Commodity prices have retreated steeply from all-time highs, postponing energy investments, fostering the first current account deficit in a decade, undercutting growth in resource-rich western provinces, and deflating Western housing

\footnotetext{
${ }^{1}$ Illiquidity in Canadian contracts and government interventions in foreign institutions may cause Canadian bank credit default swap (CDS) spreads to overstate risks.
} 
markets. Reflecting the gyrations in commodity prices, the Canadian dollar fell from above parity with the U.S. dollar in early 2008 to around four-year lows of 0.82 by end-2008.

\section{In response, macroeconomic policies have adopted an expansionary tilt and} authorities have taken steps to safeguard financial stability. Since December 2007, the Bank of Canada has cut its policy rate by 400 basis points to $1 / 2$ percent, a historic low, and expanded liquidity through enhanced facilities. In January 2009, the authorities tabled the 2009 federal budget with a fiscal stimulus of 2.8 percent of GDP. The authorities have also launched facilities to offer guarantees on wholesale borrowing for banks and insurance companies, purchased mortgage-backed securities to ease liquidity pressures, and introduced additional tools to preserve financial stability if needed (Table 1).

4. Looking ahead, policies should focus on managing the downside risks to growth and financial stability. Given the rapidly deteriorating global environment, domestic economic activity will likely decline further in the near term, before picking up on the back of the policy stimulus already in train. To dampen the downturn and hedge deflation risks, the current accommodative monetary stance should be maintained until economic recovery is firmly underway. Fiscal room exists for further stimulus, if downside risks materialize. Given the worrisome market indicators and macro-financial feedbacks, the contingency policies to deal with worsened financial stress are appropriate, and authorities should stand ready to act further, if needed. (A table in the Informational Annex summarizes past and current Fund policy advice in areas that are not the focus of this report).

\section{B. Financial Stability Amid the Turbulence}

\section{Canada's banking} system has so far displayed remarkable stability amid the global turbulence, thanks in good part to strong supervision and regulation. The financial system has avoided systemic pressures: no financial institution has failed or required public capital injections (banks have raised

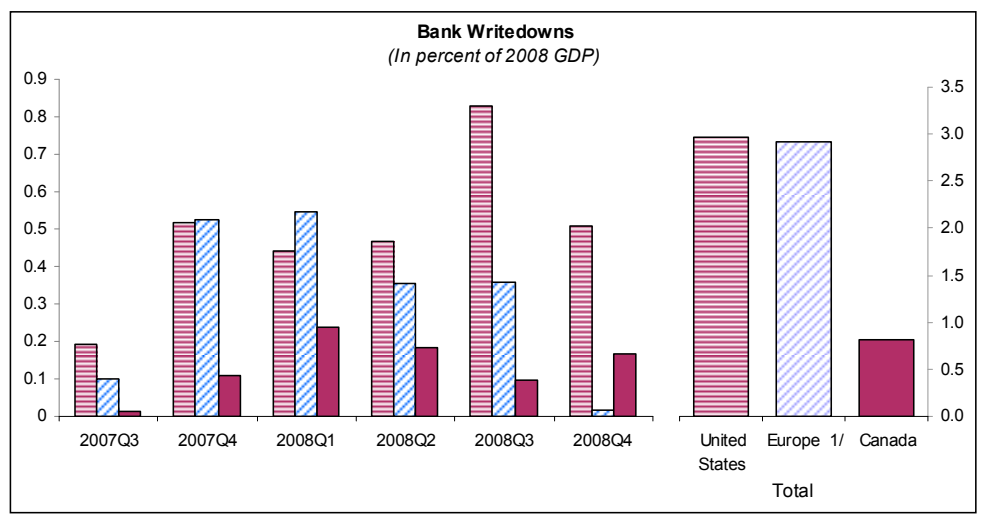

Source: Bloomberg. 1/ In percent of 2008 Euro Area GDP. capital in markets, albeit at elevated cost owing to higher global risk aversion). Key factors behind this relatively strong performance were (Selected Issues, Chapter I):

- $\quad$ Sound supervision and regulation: The 2008 FSSA Update found that the regulatory and supervisory framework meets best practice in many dimensions, including with regard to the revised Basel Core Principles for banking supervision. 
- $\quad$ Stringent capital requirements: Solvency standards apply to banks' consolidated commercial and securities operations. Tier 1 capital generally significantly exceeds the required 7 percent target (which in turn exceeds the Basel Accord minimum of 4 percent). The leverage ratio is limited to 5 percent of total capital (Box 1).

- Low risk tolerance and conservative balance sheet structures: Banks have a profitable and stable domestic retail market, and (like their customers) exhibit low risk tolerance. Banks had smaller exposures to "toxic" structured assets and relied less on volatile wholesale funding than many international peers.

- $\quad$ Conservative residential mortgage markets: Only 5 percent of mortgages are nonprime and only 25 percent are securitized (compared with 25 percent and 60 percent, respectively, in the United States). Almost half of residential loans are guaranteed, while the remaining have a loan-to-value ratio (LTV) below 80 percent-mortgages with LTV above this threshold must be insured for the full loan amount (rather than the portion above 80 percent LTV, as in the United States). Also mortgage interest is nondeductible, encouraging borrowers to repay quickly (Selected Issues, Chapter II).

- $\quad$ Regulation reviews: To keep pace with financial innovation, federal authorities review financial sector legislation every five years (Ontario has a similar process for securities market legislation).

- $\quad$ Effective coordination between supervisory agencies: Officials meet regularly in the context of the Financial Institutions Supervisory Committee (FISC) and other fora to discuss issues and exchange information on financial stability matters. ${ }^{2}$

- $\quad$ Proactive response to financial strains: The authorities have expanded liquidity facilities, provided liability guarantees, and purchased mortgage-backed securities. In addition, several provinces now provide unlimited deposit insurance for provinciallyregulated credit unions. The 2009 Budget further expands support to credit markets, while providing authority for public capital injections and other transactions to support financial stability.

\section{Nevertheless, the global turbulence has had noticeable effects on Canada's} financial markets. In mid-2007, Canada's non-bank asset-backed commercial paper (ABCP) market froze (a restructuring agreement was brokered in January 2009). ${ }^{3}$ During

\footnotetext{
${ }^{2}$ The FISC comprises officials from the Office of the Superintendent of Financial Institutions (OSFI), Finance Canada, Bank of Canada (BoC), Canada Deposit Insurance Corporation (CDIC), and the Financial Consumer Agency of Canada.

${ }^{3}$ The market for non-bank ABCP, which represented about one-third of the C\$116 billion pre-crisis Canadian ABCP market, shut down in August 2007 when issuers were unable to roll over their maturing paper, and the backstop liquidity providers refused to advance funds (see the 2008 Canada Article IV staff report for more
} 
2008, the nonperforming assets of the "big six" banks doubled to $\mathrm{C} \$ 10.2$ billion and chargeoffs increased by a third to C $\$ 5$ billion (yet representing just 0.3 and 0.2 percent of total assets, respectively). Bank profits remained positive (C\$3 billion total for the "big six" in the first quarter of 2009), albeit 20 percent down from a year ago. ${ }^{4}$ Strains were most evident among non-banks, including life insurers, pension funds, and mutual funds (Figure 6). Major financial institutions maintain fairly strong ratings, some with negative outlooks.

\section{Macrofinancial Linkages}

\section{Credit flows held up well through} the turn of the year but have ebbed more recently (Figure 7). Credit has been supported as banks have moved to fill gaps left by retrenching securities markets and finance companies. However, lending standards have tightened, with the net percentage of respondents reporting tightening in lending standards at a record high in the fourth quarter of 2008 (since data collection began in 1999), and new credit

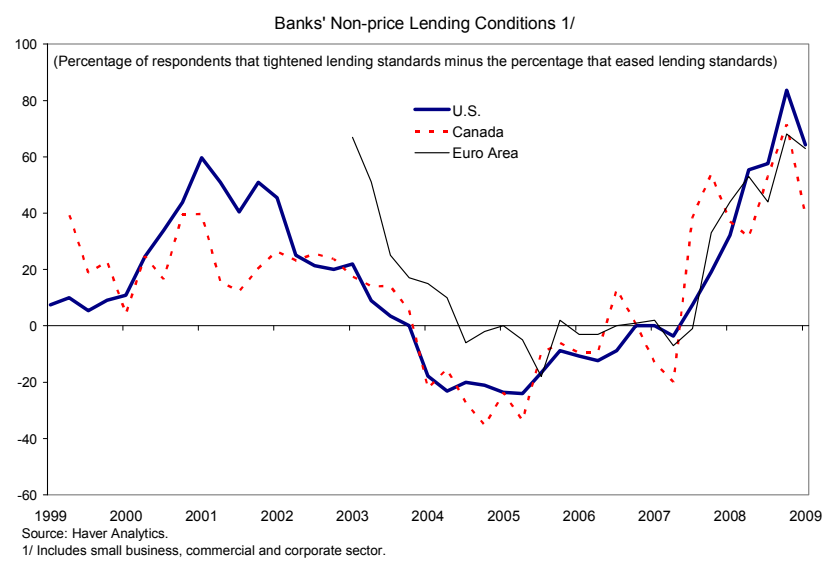
growth has slowed recently. Banks have asked for new financial instruments to be counted as regulatory capital, suggesting that capital could constrain lending. These factors point to a continued deceleration of lending, with knock-on effects to growth (staff analysis shows that lending standards affect economic activity with a lag; Selected Issues Chapter III).

\section{In addition, the credit cycle could entail adverse macro-financial feedback:}

- Weakening commodity, home, and equity prices, along with rising unemployment, are squeezing highlyindebted households, restraining consumption and credit demand. Household debt-mostly

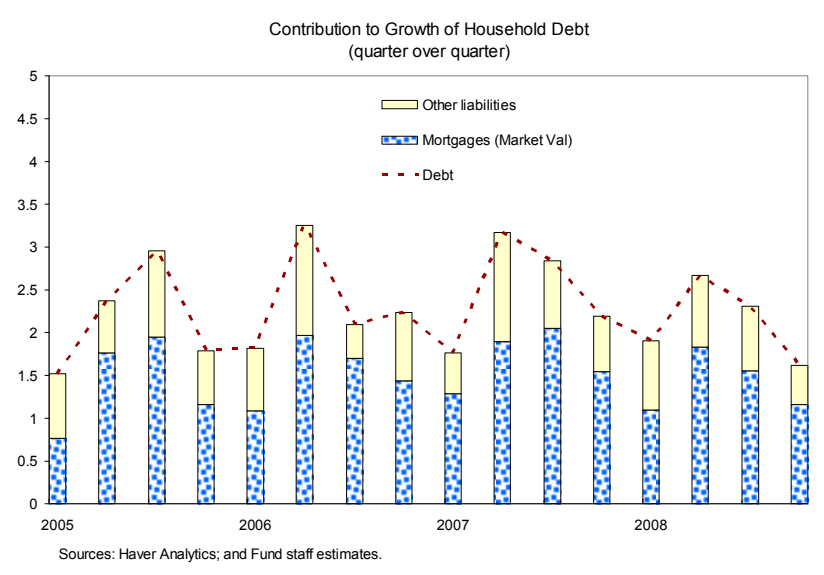
mortgages - is at record highs

details). The restructuring involved converting the frozen short-term paper into medium-term notes with terms to maturity that better matched the maturities of the underlying assets.

${ }^{4}$ Canadian Imperial Bank of Commerce is excluded from this calculation because its large write-downs of derivatives positions in 2008 hampers data comparisons. 
relative to disposable income (Figure 8). Consumer bankruptcies have swelled and are set to rise more, particularly as housing prices fall further, in turn pressuring credit quality (Figure 9).

- While corporate balance sheets are stronger than households', debt and commercial paper issuance have fallen (Figure 10).

- $\quad$ Ongoing falls in house prices, particularly in the West (which experienced a housingprice bubble; Selected Issues Chapter IV), will continue to crimp residential investment and dampen demand for business credit.

\section{Outlook and Risks}

\section{Sharply declining aggregate} demand is expected to significantly lower growth and dampen price pressures. The staff's baseline forecast is for a sharp contraction in real GDP in 2009 - the worst since 1981 when GDP plunged by 2.9 percent - followed by a return to positive growth in 2010 . Output would shrink through the first half of 2009, rebounding with fiscal stimulus. Staff models find that the U.S. downturn will be the largest drag on

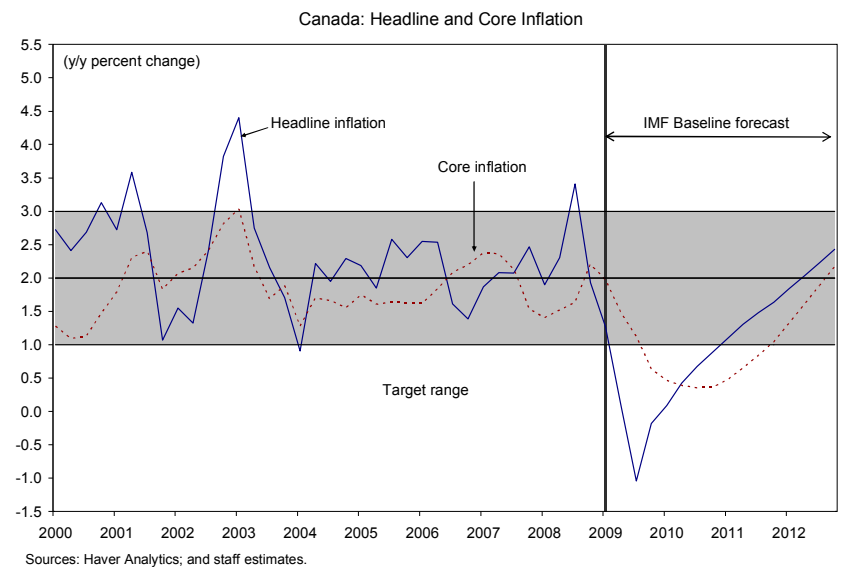
growth, followed by tighter financial conditions. House-price deflation will pose headwinds, although overheating has been regional rather than national (Selected Issues Chapter IV). ${ }^{5}$ Weak commodity prices would prolong the recession, consistent with the experience in other commodity exporters (Selected Issues Chapter V).

\section{The recession and weak} commodity prices will depress inflation. Upward price pressures from exchange rate depreciation should be more than offset by downward pressures from a large output gap. Given the sharp drop in oil prices since mid 2008, compounded by a growing economic

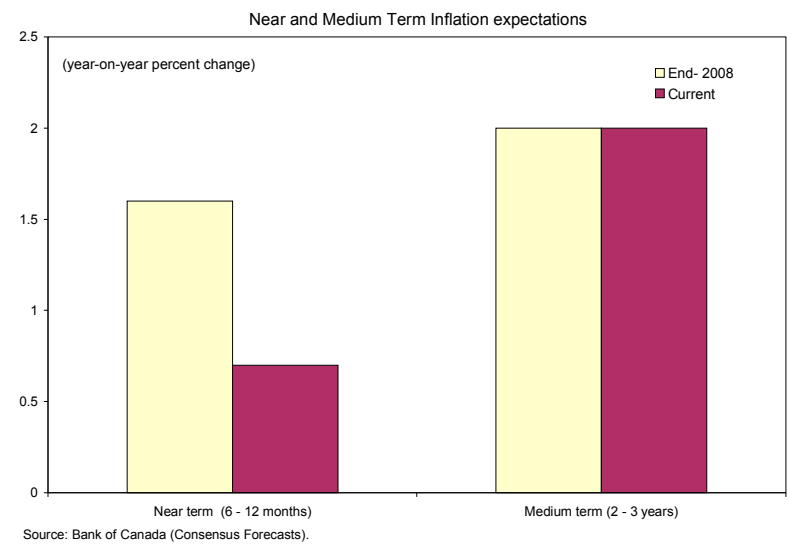

\footnotetext{
${ }^{5}$ Other IMF work has shown that, at the national level, Canadian housing prices have been in line with economic fundamentals (World Economic Outlook, September 2004 and April 2009).
} 
slack, headline inflation will be about zero on average in 2009 , remaining well below the Bank of Canada's inflation target range of 1-3 percent before rising gradually to 2 percent by early 2012. That said, medium-term inflation expectations remain well anchored at around 2 percent.

11. At the time of the mission, the authorities' projections were less pessimistic than staff's. January forecasts published by the Bank of Canada and Finance (the latter based on private forecasts adjusted for risk) have higher growth in 2010 than staff's projections. The differences mainly reflect negative data (for both Canada and globally) released since January, and staff's below-consensus outlook for U.S. growth.

12. Downside risks prevail. Larger negative spillovers would occur if U.S. real and financial conditions are worse than staff's current forecast, entailing risks of weaker growth, as well as more prolonged low inflation or deflation (a tail risk under the baseline). Financial instability in Canada is another tail risk, which would erode household and business confidence and credit flows, undercutting consumption and investment spending, with repercussions abroad (Box 2). House prices could also decline by more than expected. A larger than expected recovery in commodity prices would improve domestic demand via wealth effects, and act as an upside risk to both growth and prices.
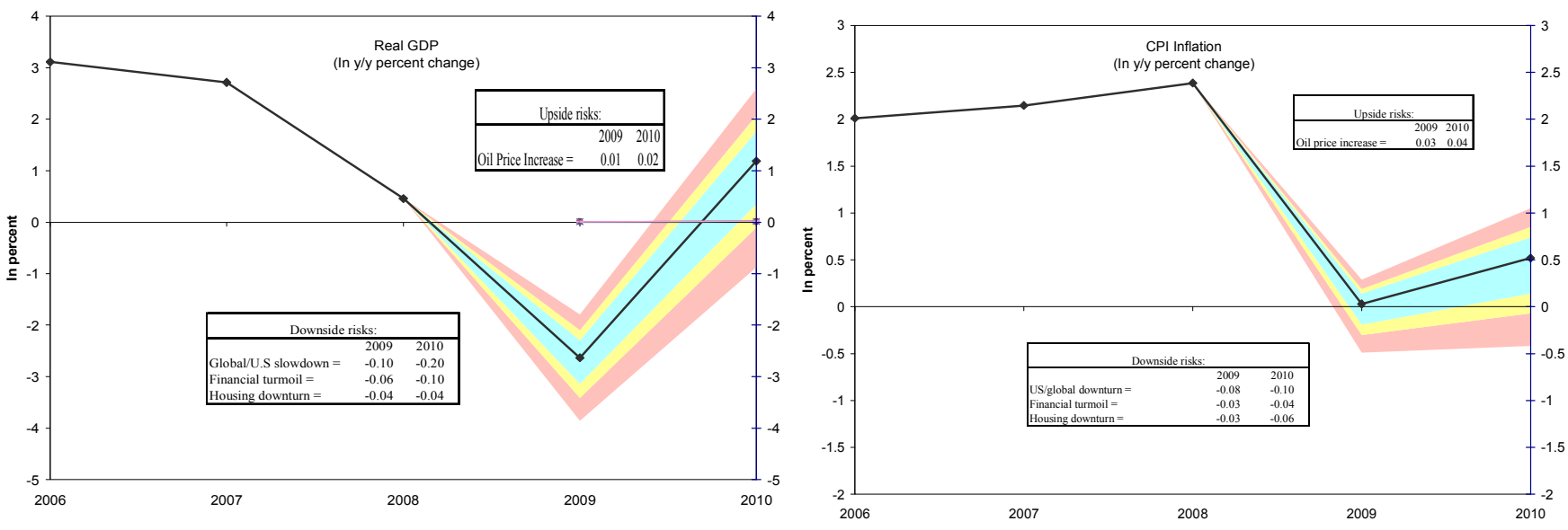

\section{Policy Responses}

Discussions focused on policies to deal with risks and vulnerabilities to the economic and financial stability outlook. Monetary and fiscal stimulus in train will support economic activity and minimize tail risks of significant deflationary pressures, and monetary policy should remain accommodative until recovery is firmly underway. Systemic financial instability is a tail risk. Nevertheless, heightened vigilance and readiness to deploy newlyformulated tools to support financial stability are warranted, to forestall worsening adverse macro-financial feedback. 


\section{A. Monetary Policy: Warding Off Deflation Risks}

\section{Staff welcomed the monetary easing undertaken so far, and agreed with the} authorities that maintaining an accommodative stance would be appropriate. Continued communication about the price stability outlook and the downside risks to inflation would signal a commitment to maintain an easy stance as long as needed to avoid an undershooting of inflation and inflation expectations. Indeed, recent measures from the Bank of Canada have gone beyond traditional open market and discount window operations, which along with the government's mortgage-backed securities purchase program, have entailed elements of unconventional easing. Bank officials noted that they are working on refining the monetary policy framework (in time for the BoC's April Monetary Policy Report) with a view to using quantitative easing measures, if needed. ${ }^{6}$ However, the authorities emphasized that monetary policy in Canada is highly effective: medium-term inflation expectations are well-anchored and the monetary transmission mechanism functions smoothly because banks are stable. Bank officials also stressed that they will continue to monitor carefully economic and financial developments to evaluate the measures required to meet the 2-percent inflation target over the medium term. That said, they saw deflationary risks as quite low. ${ }^{7}$

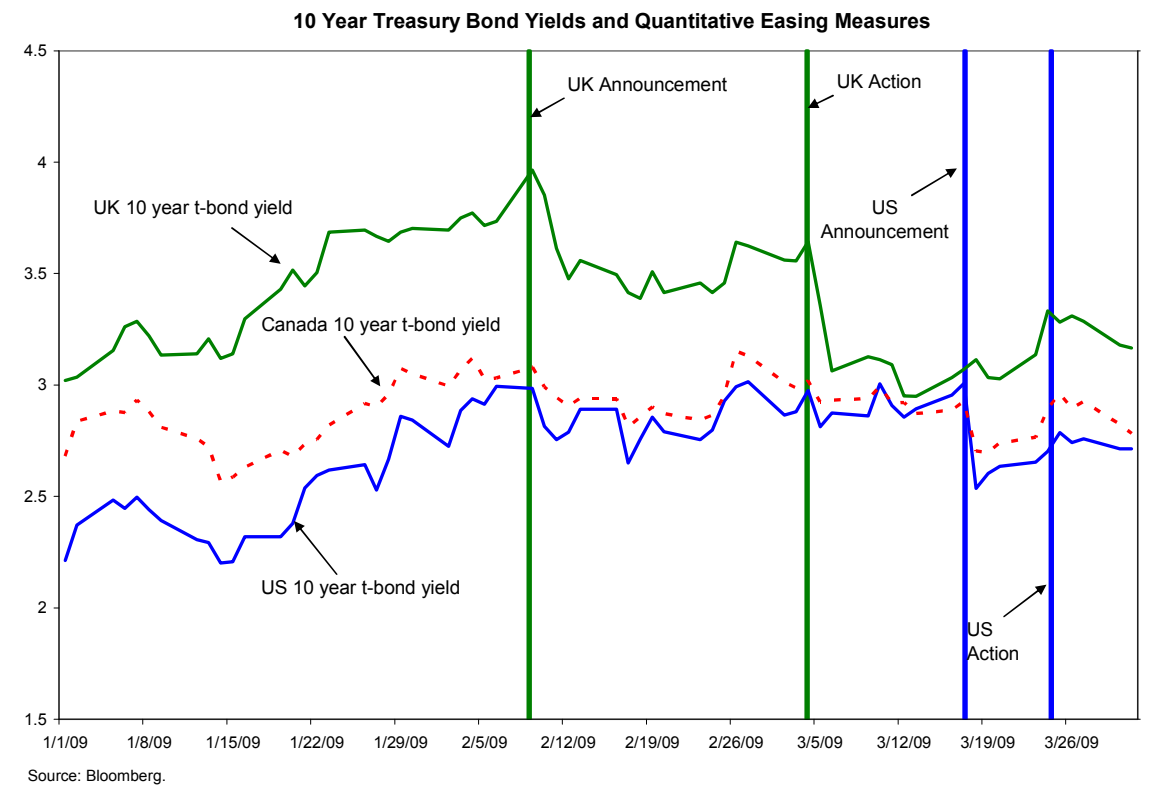

14. Staff supported the Bank's floating exchange rate policy, noting that the currency has served as an effective "shock absorber." The authorities reiterated their

\footnotetext{
${ }^{6}$ Recent quantitative easing measures in the United States and the United Kingdom have lowered long-term Treasury bond yields, as seen in the text chart.

${ }^{7}$ The mission and authorities also discussed possible changes to Canada's inflation-control target, up for review in 2011. The authorities and staff noted some space for marginal changes to the successful framework. However, dealing with the effects of the crisis is appropriately the priority.
} 
policy of letting markets determine the exchange rate. They observed that currency interventions were generally ineffective in developed-country markets, and for Canada would be reserved for countering disorderly market conditions. They pointed to the adjustment in the Canadian dollar in recent years as evidence of its flexibility, noting that around two-thirds of the recent depreciation was explained by the plunge in commodity prices. Staff's CGER exercise puts the Canadian dollar at near equilibrium (Box 3$){ }^{8}$

\section{B. Safeguarding Financial Stability to Underpin Growth}

\section{Staff welcomed the authorities' proactive response to financial strains. The} authorities have responded to market-specific stresses and enhanced their toolkit for dealing with financial instability, notably in Budget 2009. Authorities noted that many of the measures are precautionary, while some - particularly guarantees on bank liabilities - have been adopted in part to level the international playing field.

\section{Measures include:}

- $\quad$ Provision of liquidity through enhanced Term Purchase-and-Resale Agreements by the Bank of Canada, including at longer terms, for a wider set of counterparties, and with a broader range of accepted collateral;

- $\quad$ Facilities to guarantee bank and insurance liabilities under the Canadian Lenders Assurance Facility (CLAF) and Canadian Life Insurance Assurance Facility (CLIAF) (none yet drawn);

- $\quad$ Purchases of insured mortgages to boost bank liquidity and support housing finance;

- $\quad$ Purchases of securities backed by automobile loans and equipment leases through the Canadian Secured Credit Facility to bolster financing for businesses and consumers (to become operational shortly);

- Greater resources for Export Development Canada and the Business Development Bank of Canada to raise financing for corporations;

- Increased collaboration between financial Crown corporations and private sector lenders and insurers under the new Business Credit Availability Program to ease credit constraints for creditworthy businesses;

\footnotetext{
${ }^{8}$ While the crisis has pushed the current account into deficit for the first time since 1998, low external debt implies minimal risks to external stability.
} 
- $\quad$ Additional tools for the Canadian Deposit Insurance Corporation (CDIC), including ability to establish a bridge bank and own shares in member financial institutions; and a boost in its borrowing limit from $\mathrm{C} \$ 6$ billion to $\mathrm{C} \$ 15$ billion;

- $\quad$ Broader authority for the Minister of Finance to maintain financial stability via various financial operations (including capital injections).

17. The mission noted that the ongoing Canadian credit cycle and risks to international financial stability pointed to a need for continued vigilance (Box 4). Staff advised close supervisory attention to bank exposures to U.S. assets. Authorities clarified that most U.S. operations are in the retail sector; while these exposures would be affected by the U.S. downturn, banks have already provisioned or taken write-downs against specific concentrated exposures. They also noted that an intensification in the turmoil in the auto industry would mostly affect banks via declining economic activity, given their limited direct exposure. The mission further advised vigilance on exposures to commodity-affected sectors, non-banks (especially insurers and pension plans), and households, with a particular focus on cross-institution spillovers and macroprudential risks related to high household debt. The mission saw close cooperation among supervisors as especially useful, given that Canada's financial system is dominated by a few large and highly interconnected players. Cooperation between federal and provincial supervisors would be important as well, as certain institutions (like credit unions) were regulated at the provincial level.

18. Officials expressed cautious confidence in financial stability, underpinned by a conservative financial system structure, effective supervision, and relatively strong underlying fundamentals. That said, they saw no room for complacency, and would remain watchful for signs of instability. They saw the existing system of regulation and resolution as effective (including for non-banks), with the federal authorities supervising all systemically important financial institutions, and capable of dealing with contingencies (also noting that stress tests undertaken under the FSSA had proven useful in thinking through risks). In addition, banks maintain capital ratios well above Basel standards. They agreed that cooperation between federal and provincial supervisors was essential, noting that communication lines are open, and saw provincial regulators as rigorous as federal ones.

\section{Staff supported authorities' plans to move toward centralized securities} supervision, in line with recommendations of an Expert Panel on Securities Regulation and longstanding Fund advice. Budget 2009 noted the authorities' intentions to follow the Expert Panel's recommendations, and table a national securities act this year to lay the groundwork for a national regulator, which could become operational by Fall 2011. ${ }^{9}$ Staff noted that the current passport system of 13 provincial and territorial securities supervisors risks regulatory arbitrage and creates gaps in oversight, given that securities markets are

\footnotetext{
${ }^{9}$ Provincial participation would be voluntary (some provinces strongly oppose a national regulator).
} 
effectively national in scope. A federal regulator could coordinate more readily with other regulators in monitoring risks and responding quickly to a crisis, and could also have an enhanced focus on the issues that securities markets may pose for national financial stability.

\section{Staff discussed}

measures to provide relief to life insurance companies and pension funds that have been hit by the stock market downturn. These included easing capital requirements for life insurers' segregated funds, which have suffered large writedowns in recent months, and increasing from five to ten years the amount of time companies are allotted to make up funding shortfalls in their defined-benefit pension plans. ${ }^{10}$
Nominal and Real Pension Fund Returns in Selected OECD Countries, (January-October 2008)

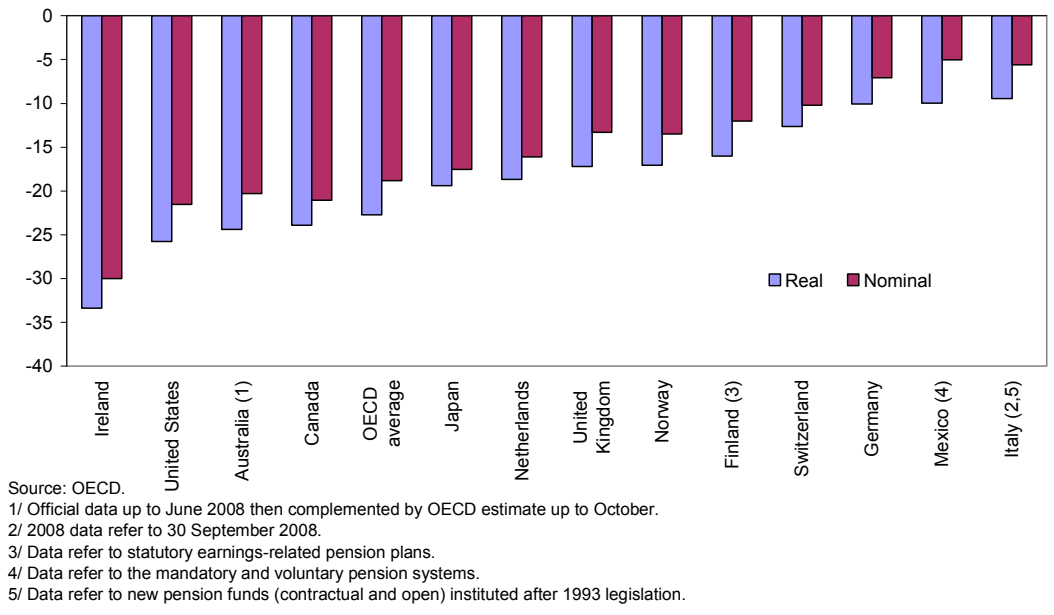

Staff and authorities agreed that these measures, while helpful, give only temporary relief, and the authorities plan to enact pension reforms (including on solvency funding rules) by end-2009. Looking beyond the current cycle, it seems likely that guaranteed insurance products and defined benefit plans will play smaller roles than in the past due to their substantial exposure to market risk, which questions the sustainability of these arrangements in volatile periods.

\section{Staff also welcomed the measures to protect the long-term stability of Canada's} housing market. Along with increased funding to mortgage markets, the Canada Mortgage Bond $(\mathrm{CMB})$ program was expanded to include a $\mathrm{CMB}$ with a 10 -year maturity to attract new investors seeking assets beyond the current five-year term; two issues, the most recent on February 18, have provided an additional $\mathrm{C} \$ 4.5$ billion in liquidity to financial institutions. The government also moved to reduce the maximum loan amortization period from 40 to 35 years, and to require down payments of at least five percent for federallyinsured mortgages.

\section{Fiscal Actions Within a Strong Framework}

22. The economic downturn coupled with fiscal stimulus will break an 11-year string of federal surpluses. Canada's strong framework based on budgetary discipline and

\footnotetext{
${ }^{10}$ A similar provision was also temporarily put in place in November 2006 and, as of end-March 2008,75 federally regulated plans (out of 1350) benefited from it.
} 
conservative forecasting has more than halved the net federal debt/GDP ratio in 10 years. Since 2006, the authorities have targeted an annual reduction of C\$3 billion in federal government debt ( 0.2 percent of GDP), aiming to bring federal debt (now at around 29 percent of GDP) to 25 percent by 2011-12. However, fiscal stimulus and the recession will foster deficits and delay achieving the 25-percent-of-GDP debt target.

23. The mission

supported the authorities' proactive fiscal response to the crisis. Staff noted that the January 2009 fiscal package was appropriately large, timely, well diversified and structured for maximum effectiveness (with a large direct spending component and matching resources from the provinces on infrastructure), building on the permanent tax relief from the 2007 Fiscal and Economic Update. All told, and taking into account supplementary provincial actions announced following the federal budget, the measures total around 2 percent of GDP per year in 2009 and in 2010, making them among the largest across G-20 countries. Notably, the January stimulus relies mainly on infrastructure spending, and support to vulnerable sectors (including housing) and provinces. It boosts safety nets, thus protecting the most vulnerable; provides training to facilitate job reallocation; and allows automatic stabilizers to be given full play. It also provides permanent tax relief, particularly to low- and middle-income households. Finally, the budget cuts external tariffs, in line with Canada's long-standing commitment to trade liberalization and openness. In this regard, the authorities noted their concern with "Buy American" provisions in the latest U.S. budget proposal, indicating that the NAFTA procurement provisions for free trade do not apply at the provincial/state level.

24. The near-term focus is on implementing the current stimulus package. The framework for quarterly monitoring of budget deployment (first review was completed in 
mid-March) will promote maximum effectiveness and provide opportunities to assess both implementation and impact. Authorities and staff agreed that the challenge would be to ensure the speedy and effective implementation of infrastructure projects, most of which will be undertaken at the subnational level. Authorities aim at having the bulk of the 2009 stimulus available for implementation as early as April, when they are legally allowed to use resources in Budget 2009. They also pointed to a "use it or lose it" clause aimed to ensure that all the spending is completed by end-FY2010.

25. The mission observed that fiscal room exists for further action, should it be needed if downside risks materialize. Staff saw the fiscal response as appropriate given Canada's situation. However, because of Canada's enviable fiscal position (the lowest debt to GDP ratio in the G-7 and among the lowest 10-year bond yields among industrial countries), and despite fiscal risks (Box 5), further stimulus would be feasible if needed. In particular, Canada would be well positioned to join in a further round of coordinated stimulus with other countries.

26. The mission discussed the limits to potential additional stimulus, although these were not seen as presently binding.Infrastructure spending had been sharply increased and would at some point face implementation constraints; larger permanent tax cuts could put at risk the underlying fiscal position; and temporary tax cuts would have limited effectiveness. The mission and the authorities agreed that automatic stabilizers should be given full play, and also concurred that Canada could join in further internationally coordinated stimulus, if needed, observing that coordination would reduce leakages from a further domestic fiscal impulse.

\section{The mission welcomed the authorities' commitment to medium-term fiscal}

prudence and debt reduction. In this connection, Budget 2009 noted the aim to avoid longterm structural deficits. Officials stressed their commitment to spending discipline (notably, caps on the public wage bill as in Budget 2009), including by limiting program spending once economic recovery is underway. The mission observed that this commitment to prudence, along with a strong track record of budgetary responsibility, underpinned Canada's fiscal credibility. Staff and the authorities agreed that the considerable uncertainty surrounding the outlook complicated setting numerical debt targets at present. Targets could be recalibrated when the outlook is clearer, further bolstering fiscal credibility. ${ }^{11}$ The mission also welcomed the creation of the Parliamentary Budget Office with a mandate to support the work of parliamentary committees.

\footnotetext{
${ }^{11}$ Medium-term targets would need to account for health care costs, which have been growing in real terms by 4.7 percent annually since 2000, and are expected to rise further as population aging intensifies (in 2001, one in eight Canadians were seniors; this will rise to one in six in 2021 and one in four in 2041).
} 


\begin{tabular}{|c|c|c|c|c|}
\hline \multicolumn{5}{|c|}{ Budget Impact of Stimulus Measures } \\
\hline \multirow[t]{2}{*}{ Measure } & \multirow[t]{2}{*}{ Nature } & 2008 & 2009 & 2010 \\
\hline & & \multicolumn{3}{|c|}{ (In percent of GDP) } \\
\hline \multicolumn{2}{|c|}{ Fiscal Stimulus in 2007 Economic Statement 1/ } & 0.7 & 0.5 & 0.5 \\
\hline Budget 2009 Fiscal Stimulus & & & 1.5 & 1.3 \\
\hline FEDERAL & & & 1.2 & 1.0 \\
\hline Expenditure & & & 0.9 & 0.8 \\
\hline Infrastructure & Temporary & & 0.4 & 0.3 \\
\hline Safety nets & Temporary & & 0.2 & 0.2 \\
\hline Housing/construction support & Temporary & & 0.3 & 0.1 \\
\hline Other & Temporary & & 0.1 & 0.1 \\
\hline Revenue & & & 0.3 & 0.3 \\
\hline PIT/exemptions/deductions & Permanent & & 0.3 & 0.3 \\
\hline PROVINCIAL (Leveraging) & & & 0.3 & 0.3 \\
\hline Infrastructure & Temporary & & 0.3 & 0.3 \\
\hline Housing support & Temporary & & 0.0 & 0.0 \\
\hline Supplementary provincial budgets & & & 0.3 & 0.3 \\
\hline Infrastructure & Temporary & & 0.2 & 0.1 \\
\hline TOTAL STIMULUS & & 0.7 & 2.3 & 2.1 \\
\hline
\end{tabular}

Sources: Finance Canada; Provincial Budgets; Fund staff estimates. $1 /$ Effects of phased revenue measures.

\section{Staff Appraisal}

28. Canada is better positioned than many countries to weather the crisis. It entered the crisis from a position of strength, reflecting a track record of strong policy management that has supported underlying macroeconomic and financial stability. It has taken proactive steps to stimulate demand, ward off deflation, and enhance the toolkit for dealing with worsening financial strains if they emerge. Thanks to these factors, the strains evident in other countries, especially in the financial sector, are markedly less serious in Canada.

\section{Nevertheless, Canada faces a challenging period ahead in light of the sharp} deterioration in the global environment and its strong international linkages.

Employment, income, and investment will come under substantial pressure, with output recovering only as the full effects of policy stimulus are felt. With economic slack widening, core inflation will ebb to low levels. Downside risks still predominate, including negative spillovers to Canada if the global environment worsens more than expected. Accordingly, the key policy priorities are continued vigilance and readiness to respond if tail risks are realized.

\section{Monetary policy should remain accommodative until disinflationary pressures} abate. The aggressive monetary easing and expanded $\mathrm{BoC}$ facilities are justified by the subpar economic outlook and liquidity pressures. Going forward, maintaining an easy stance will limit downside risks to inflation and inflation expectations. The latter can also be managed through continued clear communication of the commitment to price stability. 
Unconventional measures could help to reinforce this commitment, if downside risks materialize.

31. Fiscal policy has provided significant stimulus and authorities are rightly focused on implementation. The January stimulus package was appropriately sized, diversified, and structured, and included steps to facilitate labor reallocation and protect Canada's most vulnerable. Provincial stimulus will add to the ameliorating effects of federal measures. Moreover, the new quarterly monitoring framework will maximize the effectiveness of fiscal actions by providing opportunities to assess both their implementation and the prevailing economic environment. In addition, the move to liberalize the trade regime by lowering tariffs is welcome.

\section{Canada's sound fiscal situation would allow for further expansionary measures}

if they became necessary. With debt low, Canada would be well positioned to participate in a globally coordinated round of further stimulus. Meanwhile, automatic stabilizers can be given full play. Further fiscal expansion would not put at risk debt sustainability, in view of the credible commitment to medium-term structural surpluses. Looking beyond the crisis, debt targets could be recalibrated once the outlook becomes clearer; in the meantime, fiscal credibility could be supported by continuing to signal the commitment to medium-term consolidation.

\section{Canada's financial stability amid the turbulence bears testimony to effective} supervision and regulation. Rigorous limits on leverage and targeted capital ratios well above Basel standards have helped to avoid vulnerabilities. In addition, five-year reviews have ensured that federal regulatory legislation is modernized periodically, while regular interaction among officials has supported the smooth exchange of information needed to preserve financial stability.

\section{Consolidating and enhancing securities regulation would further strengthen the} already robust financial stability framework. Over time, bringing a greater financial stability focus to securities regulation, and achieving broader national integration, would provide a more holistic perspective to financial stability arrangements. The intention expressed in Budget 2009 to follow the recommendations of the Expert Panel on Securities Regulation is an important step in the right direction.

\section{The challenging credit cycle ahead calls for vigilance to forestall an adverse} macro-financial feedback loop. The sharp economic downturn will continue to pressure bank credit quality, with feedback onto tighter credit conditions, thus further dampening economic activity. But proactive steps to safeguard financial stability, including by augmenting the financial stability toolkit, will serve Canada well in containing this dynamic. In addition, continued close consultation among federal supervisors and regulators could focus on risks to individual institutions and cross-institution spillovers, and macro-prudential risks related to high household debt. In addition, continued close cooperation between federal 
and provincial supervisors would manage any potential spillovers between provincial and national markets.

\section{It is recommended that the next consultation occur on the usual 12-month cycle.}

\section{Box 1. Canadian Bank Regulatory Capital Requirements: Are They Tougher?}

Among the G7, only Canadian and U.S. bank regulators impose leverage caps. Elsewhere, two large Swiss banks, UBS and Credit Suisse, will be subject to leverage caps in 2013 (Table 1). ${ }^{1}$ The Canadian leverage cap is calculated on total (Tier 1 and 2) capital, and the U.S. cap on Tier 1 capital. OSFI includes some offbalance sheet exposures in its definition of assets, whereas the U.S. leverage calculation does not. (These offbalance sheet exposures include credit derivatives, financial standby letters of credit, guarantees, and surety arrangements.)

\begin{tabular}{|l|c|c|c|}
\hline \multicolumn{4}{|c|}{ Table 1: Regulatory Leverage Ratio Limits } \\
\hline Canada & Numerator & Denominator & Maximum \\
\hline Switzerland & $\begin{array}{c}\text { On-balance sheet assets plus } \\
\text { specified off-balance sheet exposures }\end{array}$ & Tier 1 \& 2 Capital & 20 \\
\hline United States & $\begin{array}{l}\text { On-balance sheet assets, but } \\
\text { excluding domestic lending }\end{array}$ & Tier 1 Capital & $33 \frac{1}{3} / 25^{\mathrm{b}}$ \\
\hline $\begin{array}{l}\text { a. Canadian specified off-balance sheet exposures include direct credit substitutes (see above), trade- and transaction-related } \\
\text { contingencies, and repurchase agreements. } \\
\text { b. The Swiss minimum leverage ratio (excluding domestic lending) will be 3 percent (at group level) and 4 percent (for the } \\
\text { individual institutions). The leverage ratio will be tighter in good times (most likely 4-5 percent). The determination of this } \\
\text { cyclical adjustment is not linked to macroeconomic conditions but the supervisory assessment once leverage increases above 20. } \\
\text { c. U.S. banks that meet certain criteria of strength and sophistication are subject to a 33 1/3 percent maximum leverage ratio. All } \\
\text { others are limited to 25 percent. }\end{array}$ \\
\hline
\end{tabular}

Canada's minimum capital requirements are tougher than called for by Basel II, and all other G7 bank regulators (Table 2). Canadian banks have to hold Tier 1 capital of at least 7 percent (versus 6 percent in the United States) of risk-weighted (RWA) assets, and 10 percent (versus 8 percent in most other G7 countries) of RWA as total capital. ${ }^{2}$

\begin{tabular}{|l|c|c|c|c|c|c|c|c|}
\hline \multicolumn{7}{|c|}{ Table 2: Tier 1 and 2 Capital Requirements as a Percent of Risk-Weighed Assets } \\
\hline & Basel II & Canada & U.S.A. & France & Germany & Italy & Japan & U.K. \\
\hline Tier 1 Capital & 4 & 7 & 6 & 4 & 4 & 4 & $4 / 2^{\text {a }}$ & 4 \\
\hline Total Capital & 8 & 10 & 10 & 8 & 8 & 8 & $8 / 4$ & 8 \\
\hline a. The higher (lower) requirements apply to internationally active (domestically oriented) Japanese banks. \\
\hline
\end{tabular}

${ }^{1}$ As part of their financial stabilization measures adopted in fall 2008, the Swiss financial market supervisor (FINMA) introduced a minimum leverage ratio that adjusts to downturns - while acknowledging the need to avoid enhancing the current downturn by tightening capital and other rules too early.

2 These comparisons do not account for potential differences in Tier 1 and 2 capital definitions from country to country, although these are believed to be immaterial. Also, supervisors may impose undocumented higher capital requirements on some banks (e.g., systemically important and/or large complex institutions). 


\section{Box 2. International Spillovers}

The slowdown is likely to result in significant aftershocks in many countries that rely on Canadian remittances. With Canada being among the main recipients of immigrants in the world - accounting for almost a fifth of its population-the current slowdown could have important implications on remittances and, thus, income in many countries, including some economies already under severe stress.

The downturn and currency depreciation would also affect tourism-dependent economies, especially in the Caribbean.

Canadian residents represent 10 percent of Caribbean tourism flows - a share that has grown rapidly in recent years (annual growth of 10 percent, compared to 2.8 percent and 4.3 percent for U.S. and European tourists). Thus, the Canadian downturn, along with the falling currency, would affect the region's growth and FDI outlook.

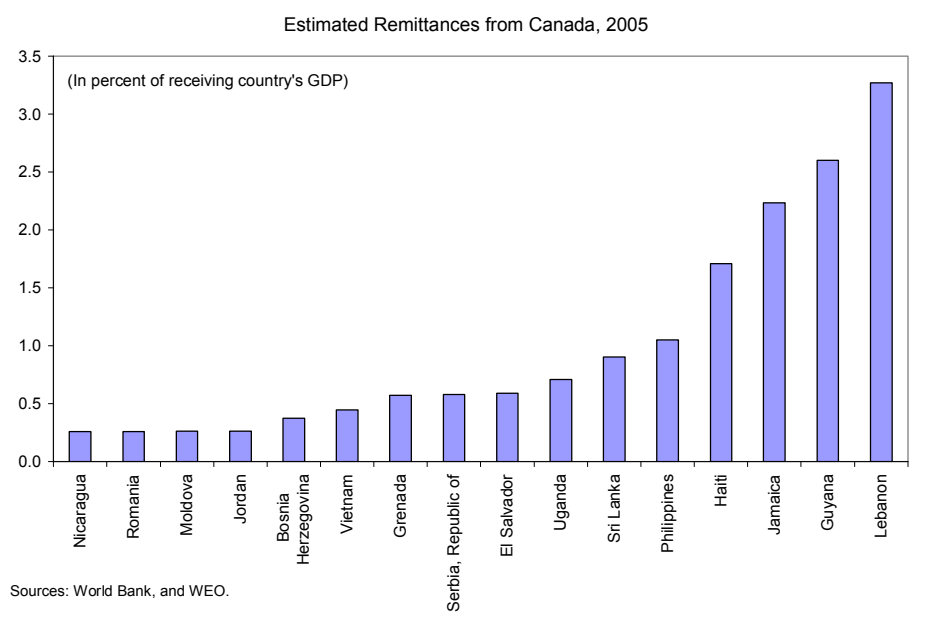

Tourism Arrivals in Select Caribbean Destinations, 2008

\begin{tabular}{lccccccc}
\multicolumn{7}{c}{ (annual percentage change) } \\
\hline Cuba & Jul & Aug & Sep & Oct & Nov & Dec & Canada's Tourism Share 1/ \\
Dominican Republic & 8.2 & 8.8 & -12.4 & -0.3 & -1.3 & 5.4 & 34.4 \\
Jamaica & -3.6 & -2.0 & -10.0 & -10.7 & -5.8 & -6.4 & 15.5 \\
Bermuda & -5.1 & 4.2 & 2.6 & -1.9 & -1.8 & -0.2 & 12.7 \\
Barbados & -1.9 & -1.2 & 3.3 & -2.6 & 0.0 & 6.8 & 10.4 \\
St. Lucia & 0.8 & -3.9 & 4.7 & -5.0 & -5.8 & -2.9 & 9.2 \\
Belize & -2.2 & 8.9 & -11.2 & -3.1 & -10.6 & -5.8 & 8.3 \\
St. Marteen & -2.5 & 1.6 & -20.7 & -9.5 & -9.2 & -2.4 & 7.0 \\
Cayman Islands & 9.7 & 12.6 & -13.0 & -13.8 & $\ldots$. & $\ldots$ & 6.8 \\
Antigua and Barbuda & 11.6 & 11.0 & -9.8 & -2.6 & -21.8 & -7.0 & 5.9 \\
\hline
\end{tabular}

Source: Caribbean Tourism Organization

$1 /$ The share of each destination's total tourism originating from Canada in 2008.

Canadian financial strains could also have repercussions abroad. Several Canadian banks have expanded U.S. operations, while some institutions (such as Scotia, RBC, and CIBC) have large retail presences in the Caribbean, holding about half of retail deposits in the Eastern Caribbean. A few banks also operate in Latin America. The major insurers are among the world's largest; Manulife, for example, is the largest insurance company in North America by market capitalization and the fourth largest globally.

\begin{tabular}{lc}
$\begin{array}{c}\text { Canadian Banks' Position in North America } \\
\text { April } 12009\end{array}$ \\
\hline & $\begin{array}{c}\text { Market Capitalization } \\
\text { (current; US \$ billions) }\end{array}$ \\
\cline { 2 - 2 } & \\
JP Morgan & 99.9 \\
Wells Fargo & 60.3 \\
Goldman Sachs & 53.5 \\
Royal Bank of Canada & 51.7 \\
Bank of America & 43.7 \\
Toronto Dominion & 36.9 \\
The Bank of NY Mellon & 32.5 \\
Bank of Nova Scotia & 31.5 \\
US Bancorp & 25.6 \\
Bank of Montreal & 17.8 \\
CIBC & 17.5 \\
Citigroup & 13.9 \\
PNC & 13.0 \\
BB\&T & 9.5 \\
\hline
\end{tabular}

Source: Bloomberg.
End-September 2008 foreign bank's claims on Canada by nationality of reporting banks

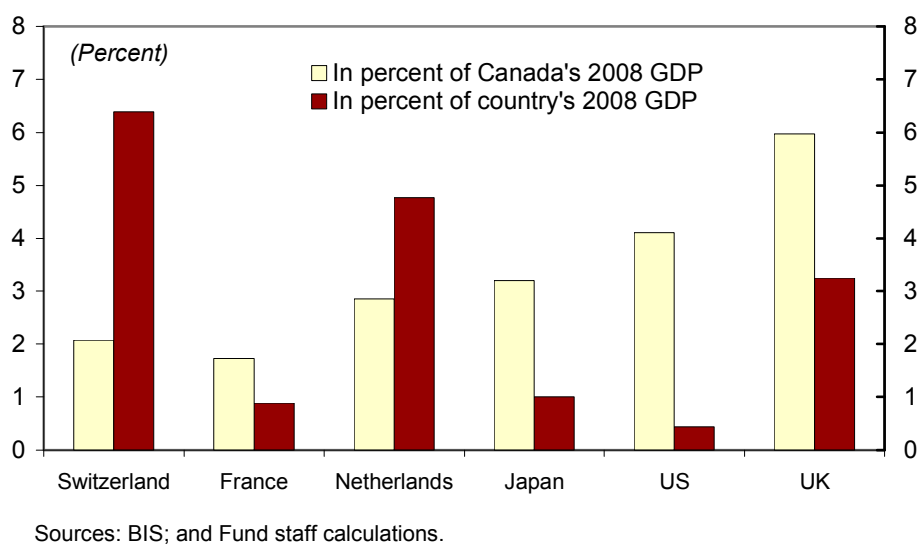




\section{Box 3. Exchange Rate Assessment}

The Canadian dollar has depreciated considerably following the plunge in commodity prices. The loonie is close to a 4-year low against the U.S. dollar while it is close to a 7-year low against the Japanese yen - Canada's third largest trading partner after the United States and the European Union. Depreciation pressures started to emerge in early 2008 , driven partly by broadbased U.S. dollar strength amid decreasing risk appetite. In effective terms, the nominal and real exchange rates have fallen by around 17 percent since early 2008, with most of the depreciation occurring in the midst of the financial market turmoil.

The last time the Bank of Canada intervened in foreign exchange markets to affect movements in the Canadian dollar was in September 1998. Prior to September 1998, Canada's policy was to intervene systematically in the foreign exchange market to resist, in an automatic fashion, significant upward or downward pressure on the Canadian dollar. Since September 1998, however, the policy has changed and Canada intervenes in foreign exchange markets on a discretionary basis.

Three approaches have been applied to assess the level of the Canadian dollar relative to its medium-term equilibrium level, based on the estimates by the IMF's Consultative Group on Exchange Rate Issues (CGER) which provides exchange rate assessments for a number of advanced and emerging economies from a multilateral perspective. The complementary approaches are (i) the "macroeconomic balance" approach (MB) based on the gap between the projected medium-term current account and a "CA norm" which takes into account the impact of the oil trade balance, (ii) the reduced-form "equilibrium real exchange rate" approach (ERER) - where the equilibrium RER is estimated as a function of the country's medium-term fundamentals (such as the net foreign asset (NFA) position, the relative productivity differential between the tradable and nontradable sectors, and the terms of trade), and (iii) the "external sustainability" approach (ES) — which calculates the difference between the actual current account balance and the balance that would stabilize the NFA position of the country at some benchmark level. ${ }^{1}$ The ERER approach is probably best suited to assessing Canada's currency, as it explicitly accounts for commodity price fluctuations.

According to these approaches, the Canadian dollar is estimated to be close to equilibrium, based on exchange rates as of February 2009:

- According to the macroeconomic balance approach, the Canadian dollar is above fundamentals by about 4 percent. This assessment hinges on an estimated current account norm of around 0.9 percent of GDP; estimates of the norm are derived from a panel of 55 advanced and emerging economies over 1973-2006. 
- The external sustainability approach implies that the currency is about 6 percent below fundamentals.

- The equilibrium exchange rate approach — staff's preferred approach for Canadasuggests that the currency is at equilibrium, with the terms of trade, the productivity differential, and net foreign assets as the main determinants.

Nevertheless, derivative prices imply increasing risk of large nearterm currency moves.

- Implied volatility - a measure of market uncertainty—on loonie/dollar option contracts is significantly above past peaks at short maturities. ${ }^{2}$

- That said, the term structure of implied volatilities slopes downward, suggesting less

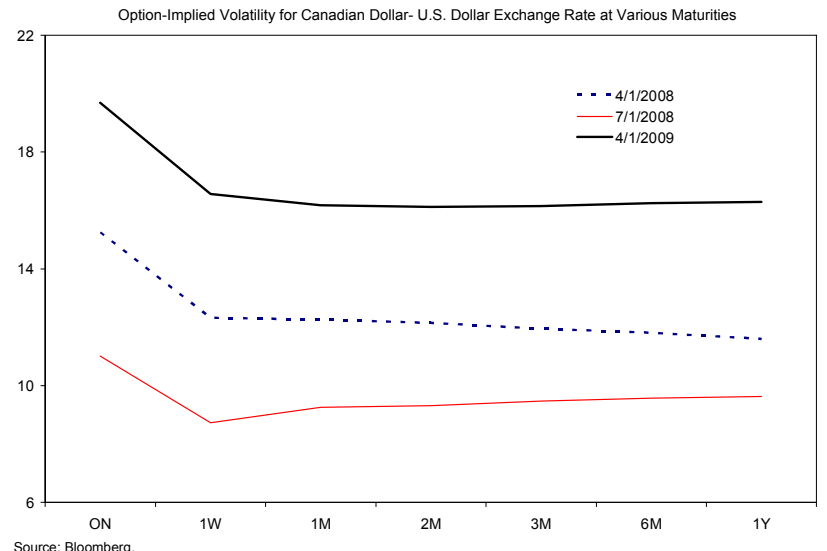
uncertainty about exchange rate moves over longer horizons.

- Forward CAD interest rates have moved in line with the U.S. dollar, and "risk reversals" put no premium on Canadian dollar appreciation versus the U.S. dollar.

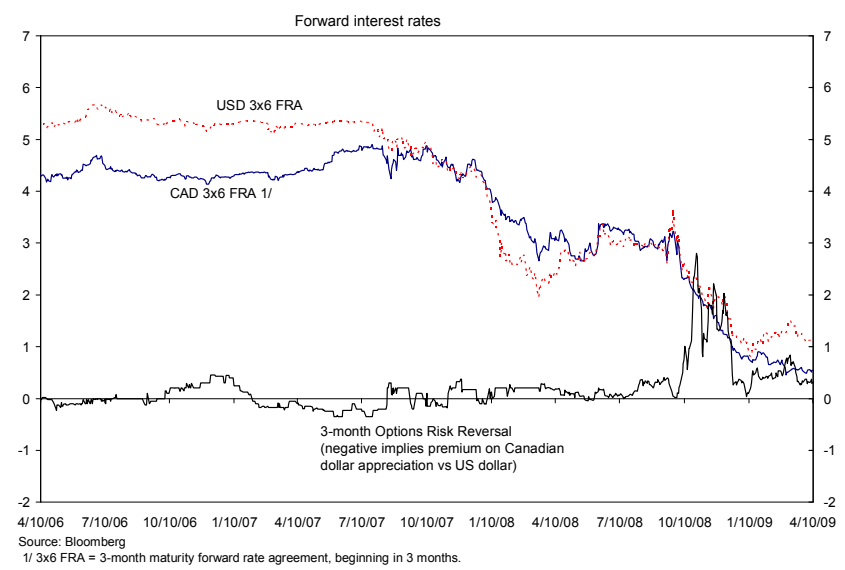

${ }^{1}$ For further details of these methodologies, see IMF (2008), "Exchange Rate Assessments: CGER Methodologies," Occasional Paper No. 261.

2.Implied volatility is an estimate of market uncertainty about future asset-price moves extracted from option prices. If investors were risk neutral, implied volatility would be equal to the market estimate of the standard deviation of asset price changes. 


\begin{tabular}{|c|c|c|c|c|}
\hline \multirow{2}{*}{\multicolumn{5}{|c|}{$\begin{array}{l}\text { Box 4. Canadian Bank Losses: Implications } \\
\text { FSSA Stress Test Assumptions Versus IMF Forecast } \\
\end{array}$}} \\
\hline & & & & \\
\hline \multirow[b]{3}{*}{ United States } & \multicolumn{2}{|c|}{$\begin{array}{l}\text { Stress-test assumptions: } \\
\text { contraction in } 2007 \text { and } \\
\text { rebound in } 2008\end{array}$} & \multicolumn{2}{|c|}{$\begin{array}{l}\text { IMF baseline forecast: } \\
\text { contraction from second } \\
\text { half of } 2008 \text { and leveling in } \\
\text { second half of } 2009\end{array}$} \\
\hline & 2008Q1 & 2009Q1 & 2009Q2 & 2010Q2 \\
\hline & & & & \\
\hline GDP growth (YOY) & -6.2 & 3.2 & -3.4 & -0.6 \\
\hline Unemployment rate & 7.7 & 8.0 & 8.7 & 10.3 \\
\hline $\begin{array}{l}\text { Core CPI inflation } \\
\text { Canada }\end{array}$ & -2.0 & -0.7 & 0.6 & -0.8 \\
\hline GDP growth (YOY) & -4.3 & 2.0 & -3.0 & 1.2 \\
\hline Unemployment rate & 8.0 & 9.4 & 8.9 & 9.3 \\
\hline Core CPI inflation & -0.6 & 0.3 & 1.5 & 0.4 \\
\hline
\end{tabular}

Adapting the macroeconomic stress test from the $\mathbf{2 0 0 8}$ Financial System Stability Assessment of Canada to the current outlook, staff estimates possible bank capital losses of 1 to 2 percentage points in the next two years. Compared to the outlook, the stress test envisaged a contraction of U.S. and Canadian GDP twice as large but with a faster rebound, broadly similar unemployment, and pronounced U.S. deflation. The stress test anticipated bank losses of 2.5-3.5 percentage points of capital. Extrapolating (by assuming that changes in the original stress test have a linear impact on bank capital), the current macroeconomic outlook can result in losses of about 1 to 2 percentage points of capital.

Corrections in housing prices could also cut bank capital by $1 / 2$ to 1 percentage point in two years. The FSSA presented a separate test (not additive to the results above) assuming declines in real estate prices of 30 percent in Western Canada and 15 percent in Eastern Canada, projecting bank losses of about 4 percentage points of capital. Staff currently estimates that residential real estate in Canada is overvalued by about 7 percent in Western Canada, but in line with fundamentals in Eastern Canada. Using the FSSA parameters, a housing correction would lead to bank losses of about $1 / 2$ to 1 percentage point of capital, taking into account a possibility of modest price overshooting on the downside.

Under a stress scenario, banks could approach or breach national capital thresholds and need to raise additional capital. As of February 2009, the six largest Canadian banks had tier 1 capital ratios above 9 percent (compared to the Basel Accord minimum of 4 percent and a national target of 7 percent) and total capital ratios above 11 percent (compared to the Basel

\begin{tabular}{|l|cc|}
\hline \multicolumn{3}{|c|}{ Capitalization of Canadian banks } \\
\hline & Tier $\mathbf{1}$ & Total \\
\cline { 2 - 3 } & 10.2 & 12.9 \\
Bank of Montreal & 9.5 & 11.4 \\
CIBC & 9.8 & 14.8 \\
National Bank of Canada & 10.0 & 14 \\
Royal Bank of Canada & 10.6 & 12.5 \\
Toronto Dominion & 10.1 & 13.6 \\
\hline Basel Accord minima & 4 & 8 \\
Canadian target ratios & 7 & 10 \\
& & \\
\hline \multicolumn{2}{|l}{ March 2009. Source: Bloomberg } \\
\hline
\end{tabular}
Accord minimum of 8 percent and a national target of 10 percent). Although banks are likely to remain comfortably above the Basel minima, some may approach or even breach national targets without new capital. Since the beginning of the turmoil Canadian banks raised over $\mathrm{C} \$ 16$ billion of tier 1 capital in markets, which has more than offset the effects of provisions and writedowns on capital ratios. With the outlook for markets uncertain, the facility for public capital injections could be tapped if needed. 


\section{Box 5. Fiscal Risks}

There are increasing risks to the fiscal outlook, stemming from a more protracted recession and deflation, worsening financial conditions, declining asset and commodity prices, and sectoral problems.

- $\quad$ Recession and deflation. Authorities' calculations suggest that, if real GDP growth slows by 1 percentage point, then the federal deficit would rise by $\mathrm{C} \$ 3.1$ billion (around one-fifth of 1 percent of GDP). If GDP inflation is a percentage point lower, then Canada's budget deficit would be 0.1 percent of GDP higher.

- $\quad$ Public support to financial sector. The preemptive measures undertaken to support financial stability have had minimal fiscal impact thus far but represent contingent liabilities. While the need for public capital injections appears remote, as institutions remain solidly capitalized and have successfully raised private capital so far, this option cannot be ruled out.

- $\quad$ Rollover/liquidity squeeze. While staff analysis suggests that Canada's medium-term public net debt position will not exhibit stresses under various scenarios (e.g., lower growth outcome than envisioned or increasing contingency liabilities), there is the risk that markets may require higher interest rates if government bond supply increases sharply (although alternatively, Canadian government bonds may benefit from "safe haven" flows). With around half of net debt maturing within one year, near-term gross funding requirements are rising in importance for Canada, although debt roll-over risks remain minimal.

- Worsening pension plans performance. With investments in equities and mutual funds of over 10 percent of GDP, large public and private pension funds are highly exposed to financial turmoil. While the Canadian pension plan (CPP) is expected to rely only on contributions until 2019 to pay benefits, the Quebec pension plan is under increasing pressure after incurring a record loss of around US\$7 billion (a fourth of its net assets) in 2008 on asset sales and writedowns tied to insolvent issuers of Canadian commercial paper. The largest risk stems from a possible support for private pensions, given their rising unfunded liabilities.

- $\quad$ Asset and commodity price declines. Staff estimates for G-20 countries suggest that a 10 percent decline in equity prices decreases cyclically-adjusted revenues by 0.07 and 0.08 percent of GDP in the current and subsequent year, while a similar fall in real housing prices decreases revenues by 0.27 percent of GDP in the following year. Canada would also lose around $3 / 4$ percent of GDP in revenues due to the decline in commodity prices, with increasing risks on corporate income taxes given the weakening business outlook.

- $\quad$ Collapse of the automobile sector. The authorities (including the Government of Ontario) have pledged about $\mathrm{C} \$ 4$ billion in loans to the automobile sector in 2009, representing a contingent liability to the fiscal accounts in view of the large risks faced by the sector. 
Figure 1. Canada: Entering Crisis on a Strong Footing
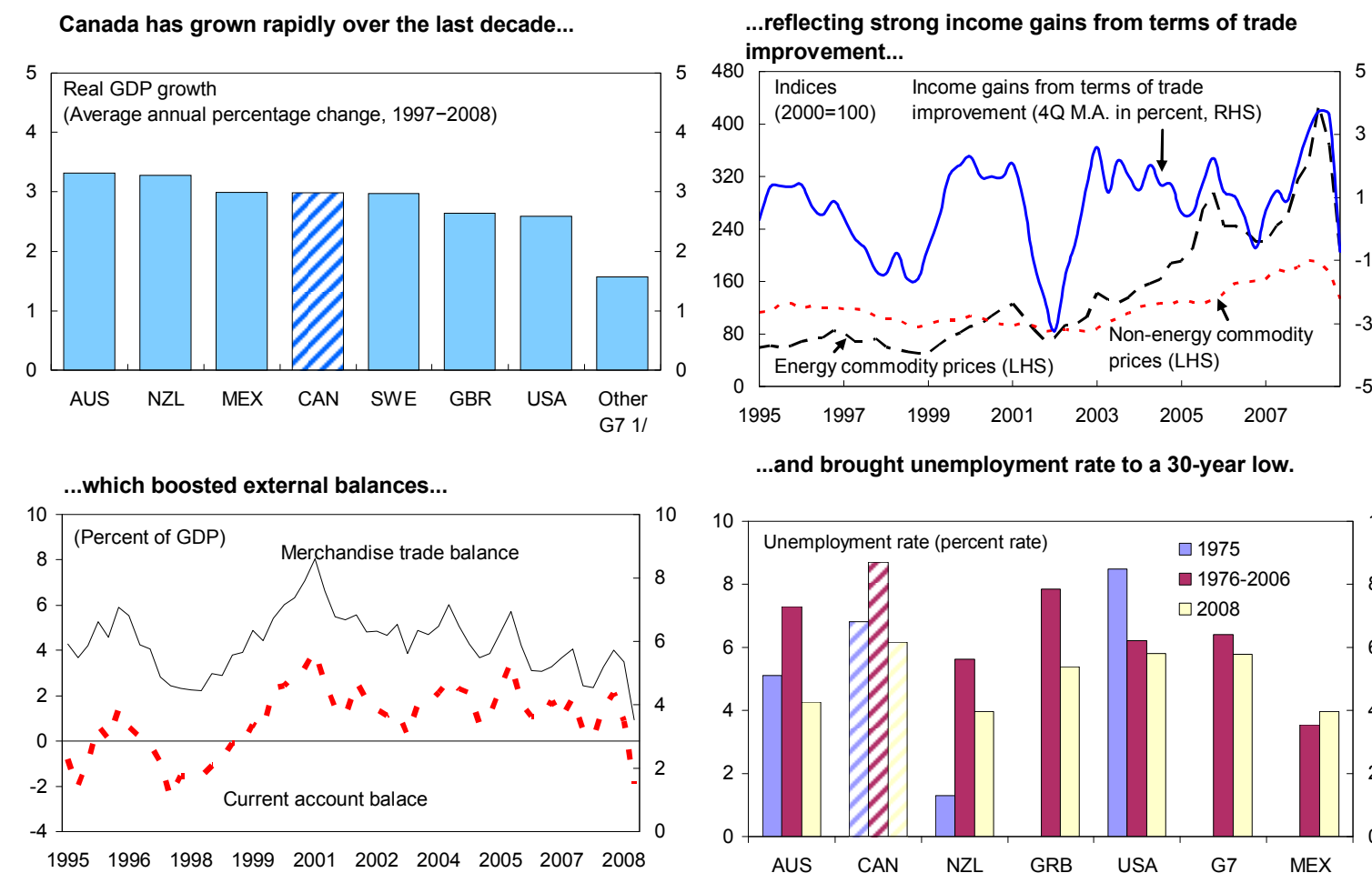

....and brought unemployment rate to a 30 -year low.

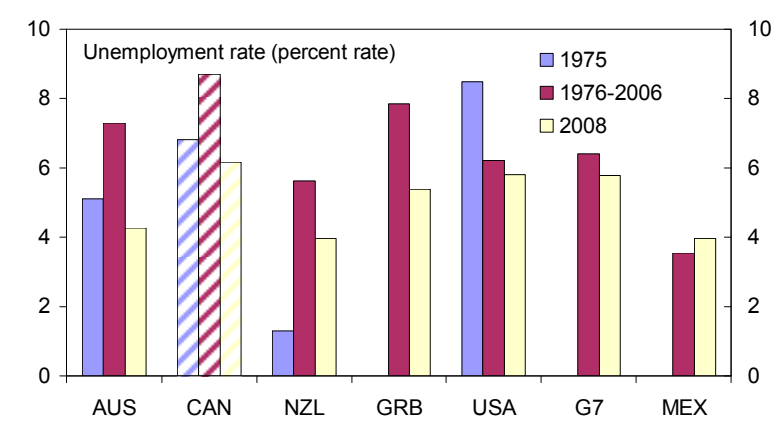

The IT framework provided price stability...

...while consistent budget surpluses...
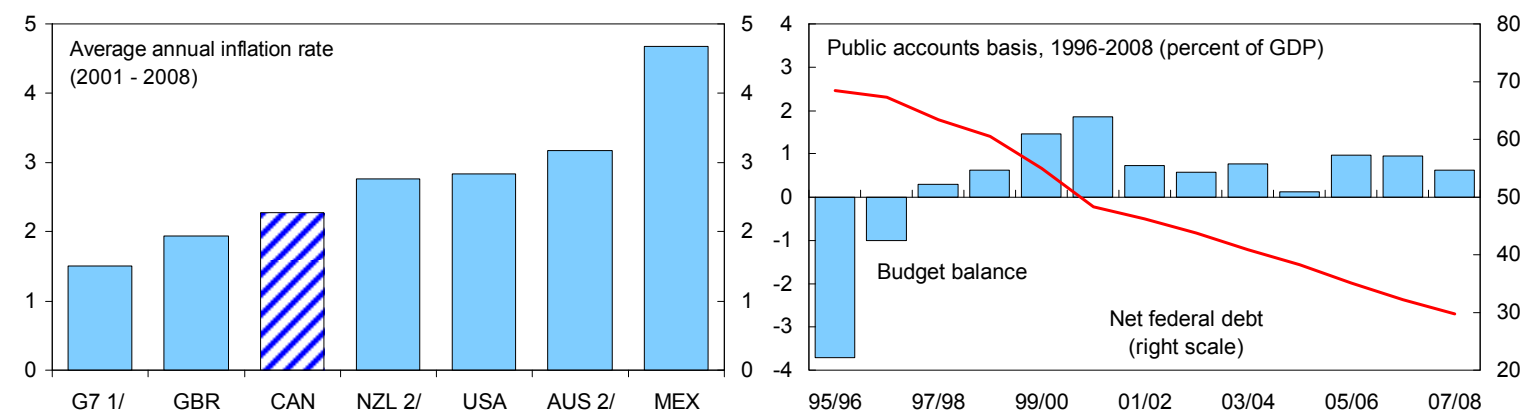

...made government debt the lowest among G-7.

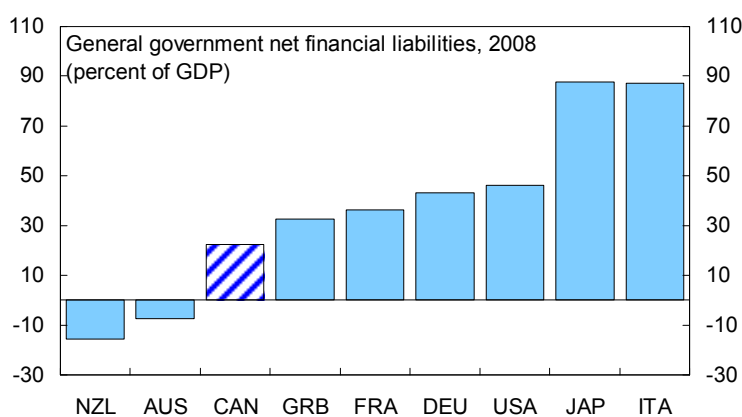

A recent survey graded Canada's banking system as the soundest in the world.

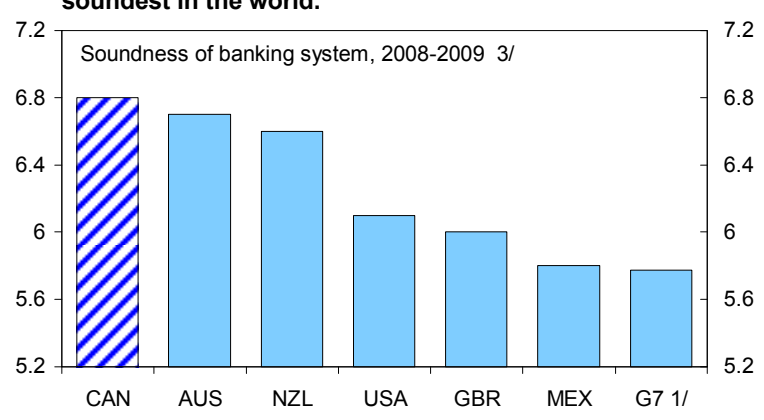

Sources: Haver Analytics; Organization for Economic Cooperation and Development; International Monetary Fund, World Economic Outlook; World Economic Forum, Global Competitiveness Report 2008-09, and IMF staff estimates.

1/ Average. Excludes Canada, U.K., and the U.S.

2/ Based on quarterly instead of monthly data.

$3 /$ Score between 1 and 7 . 
Figure 2. Canada: External Developments

The nominal trade balance has been largely driven by commodity prices...

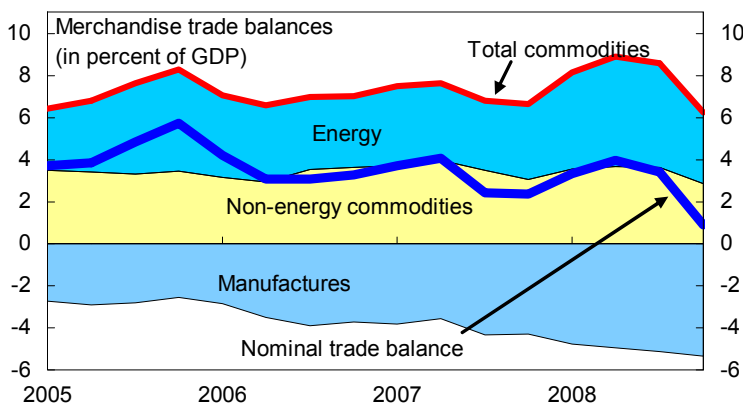

...but the real trade balance has deteriorated with rapidly rising import volumes, given the strong Canadian dollar until mid-2008.

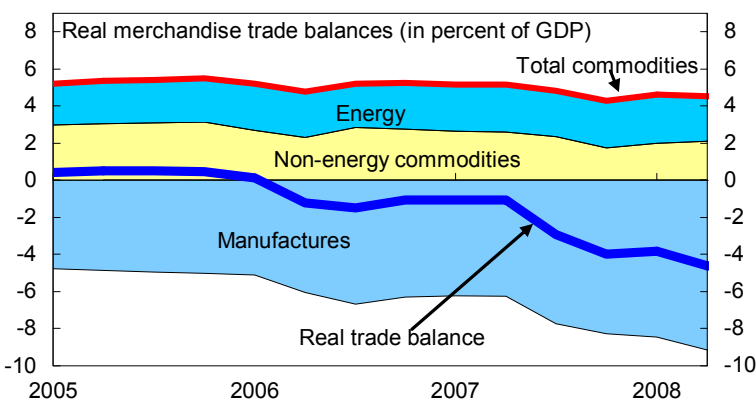

...while the U.S. has remained the dominant export destination.

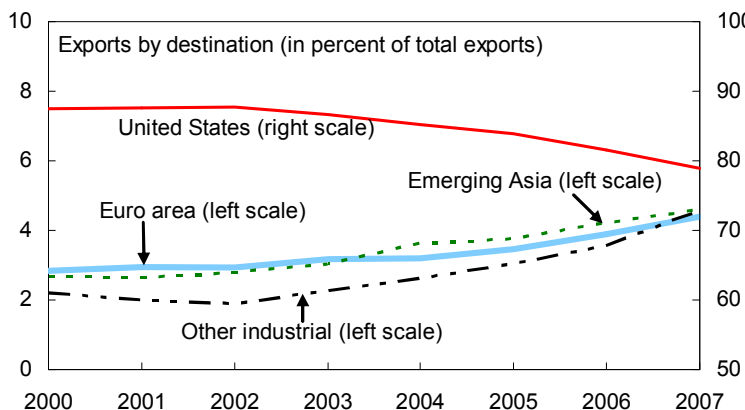

...leading to declining net foreign liabilities and lower income payments.

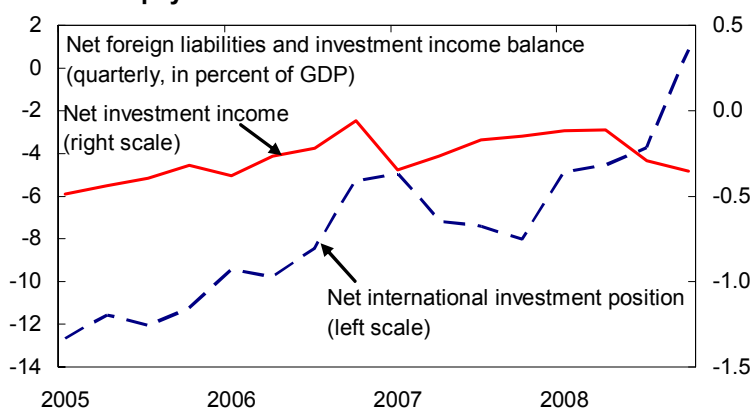

...as well as increasing net energy export volumes..

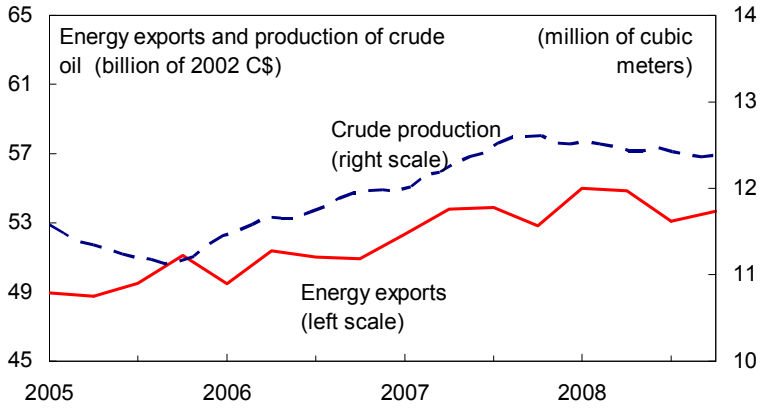

...partly reflecting a larger share of imports from Emerging Asia..

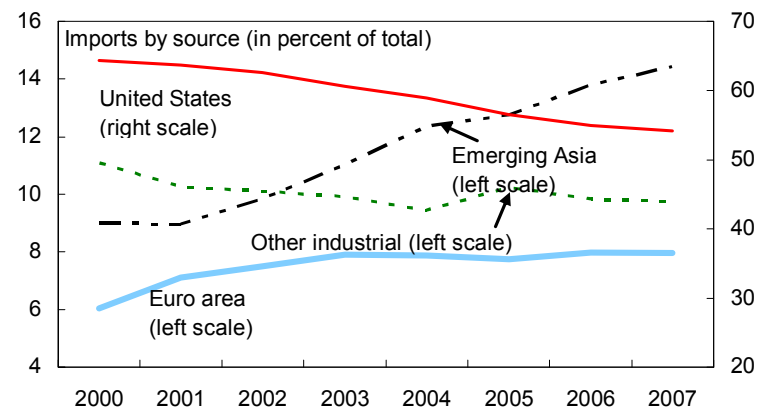

Strong commodity prices had supported current account surpluses...

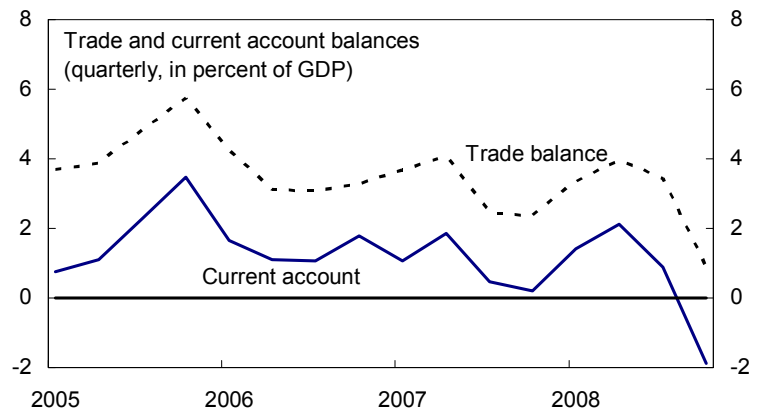

...while the commodity boom had boosted net direct investment inflows.

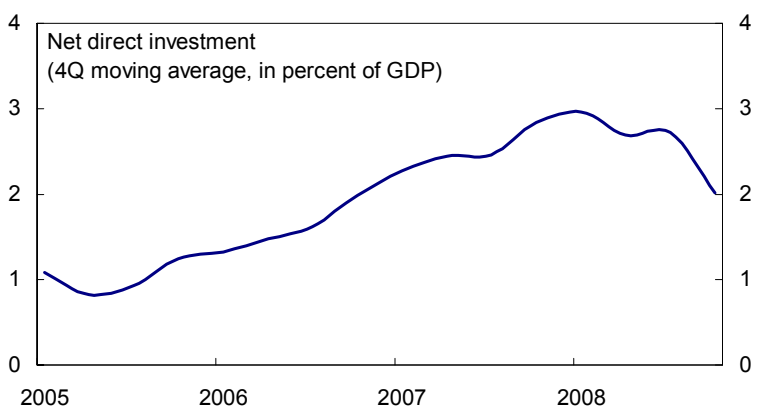

Sources: Haver Analytics; International Monetary Fund, Direction of Trade; and IMF staff estimates. 
Figure 3. Canada: Impact of the Crisis on Economic Growth Growth has declined, driven by a drag from net exports...

...reflecting weak external environment and past CAD

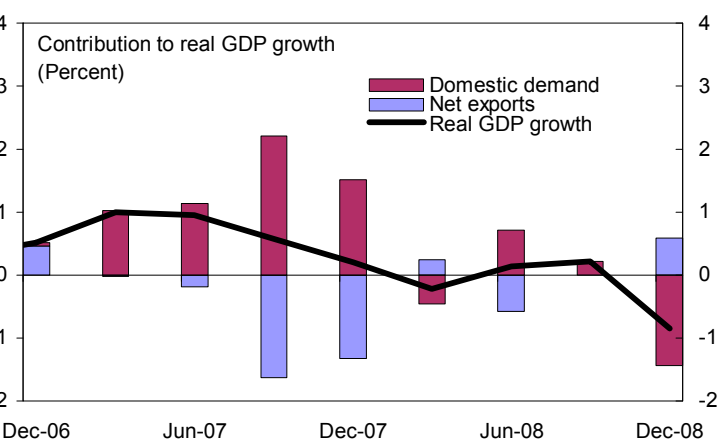
appreciation...

...and, more recently, softening domestic demand...
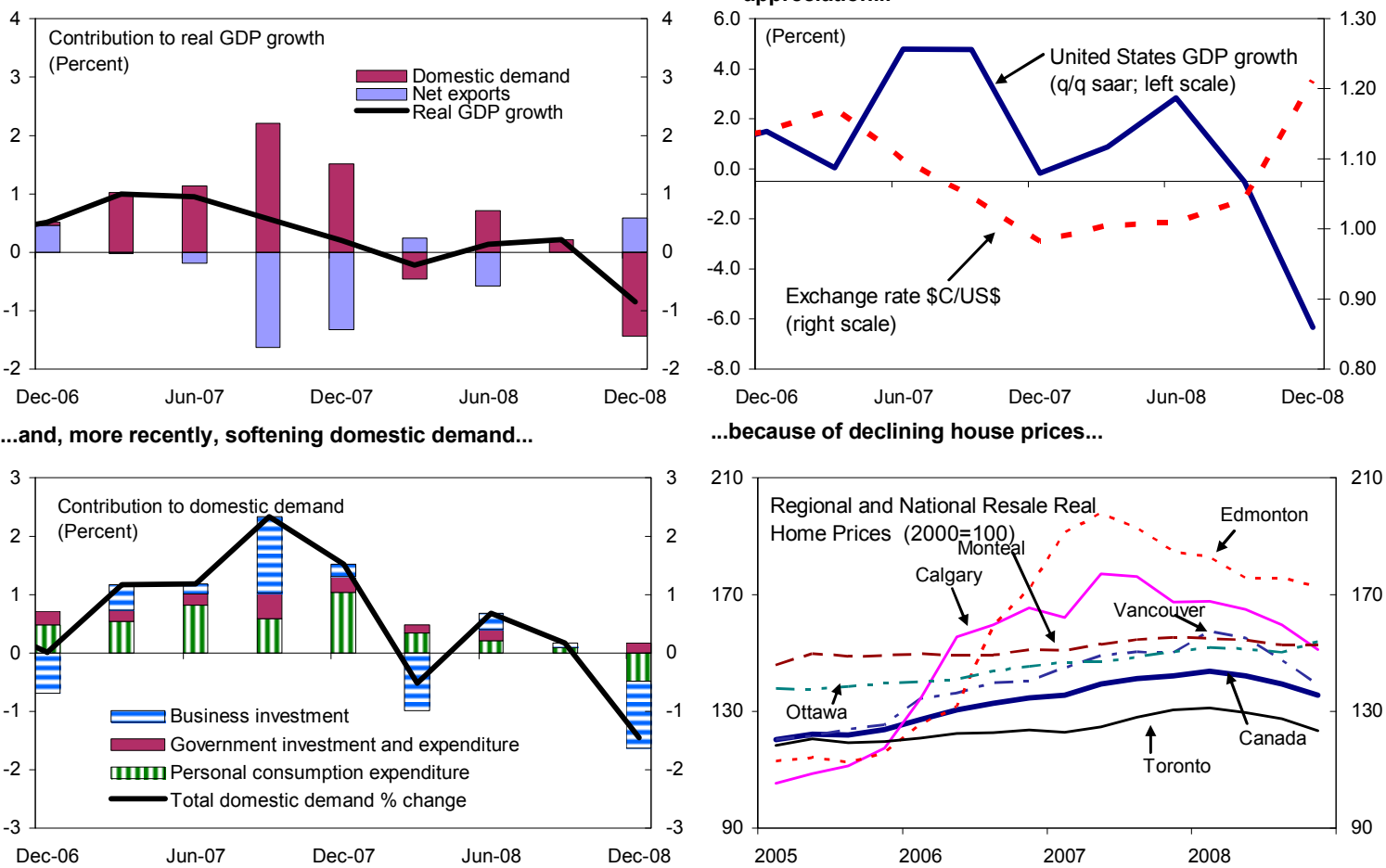

...because of declining house prices..

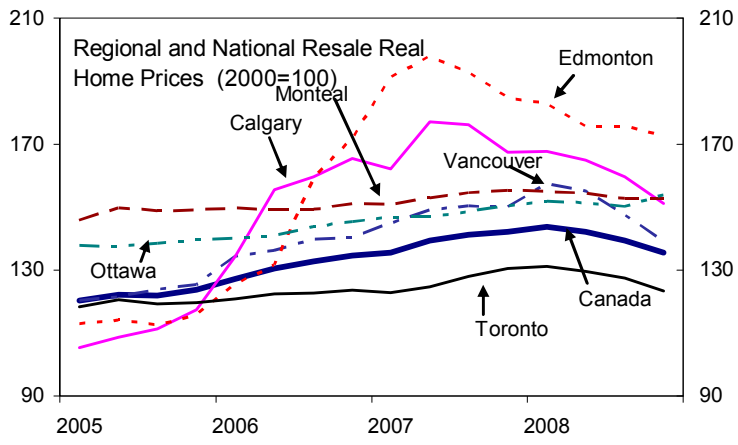

...and a sharp retreat in commodity prices.

The recent financial meltdown has worsened the outlook...
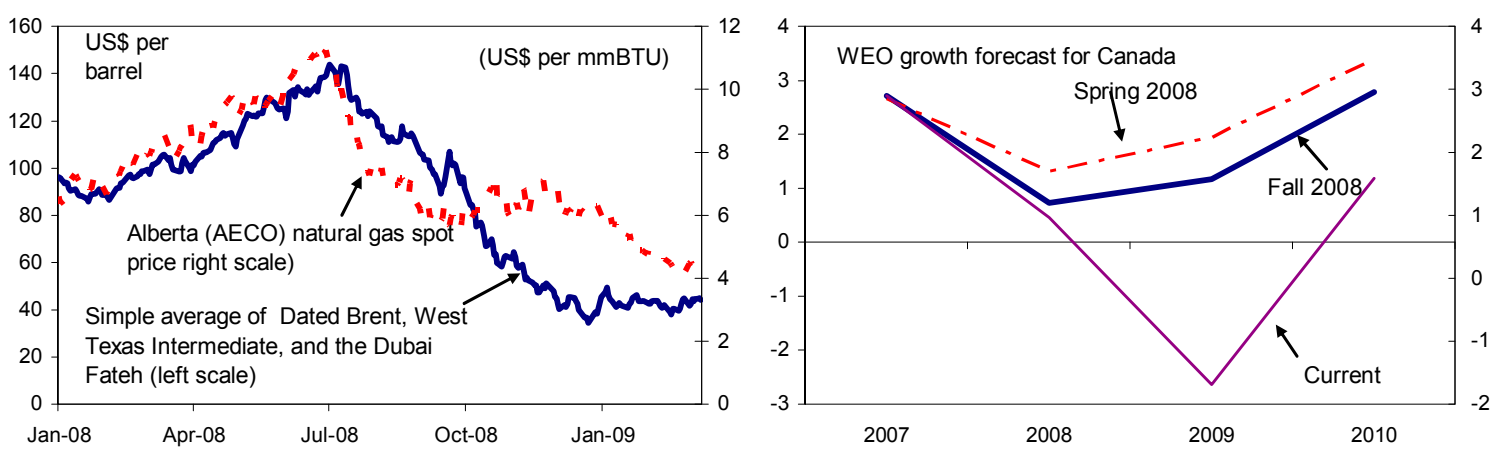

...amid declining employment prospects and increasing credit constraints...

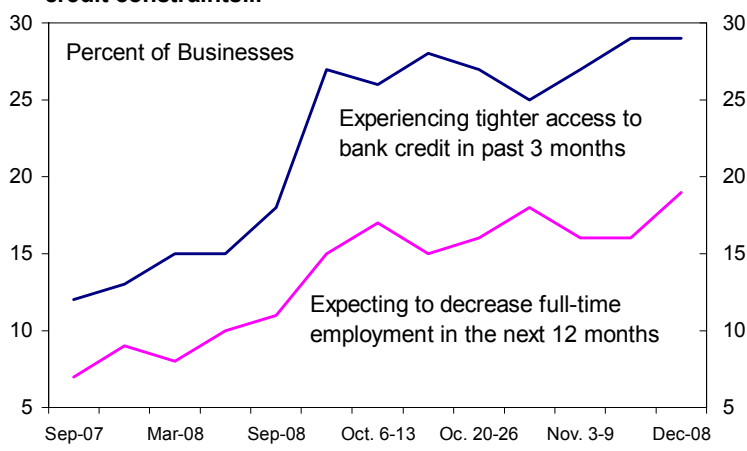

...even in the previously booming western provinces.

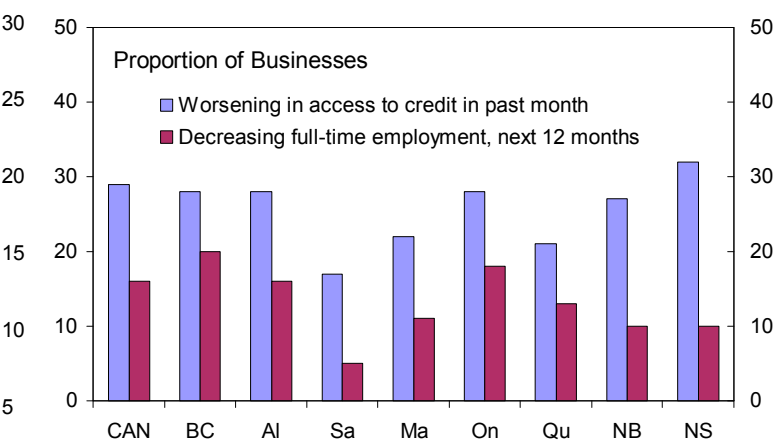

Sources: Haver Analytics; Canadian Federation of Independent Business, Finance Canada; Royal-Lepage; Bank of Canada; Bloomberg; World Economic Outlook, IMF; and staff estimates. 
Figure 4. Canada: Strains in the Financial Market

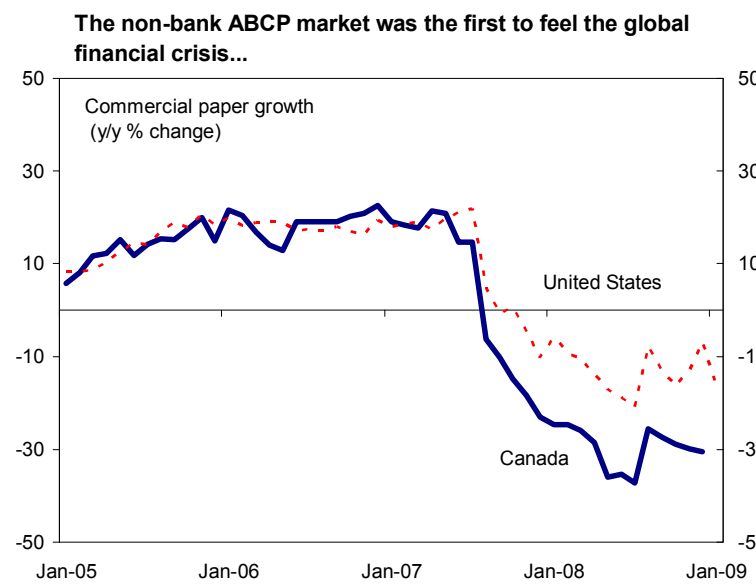

...and despite accommodating monetary policy.... financial crisis..
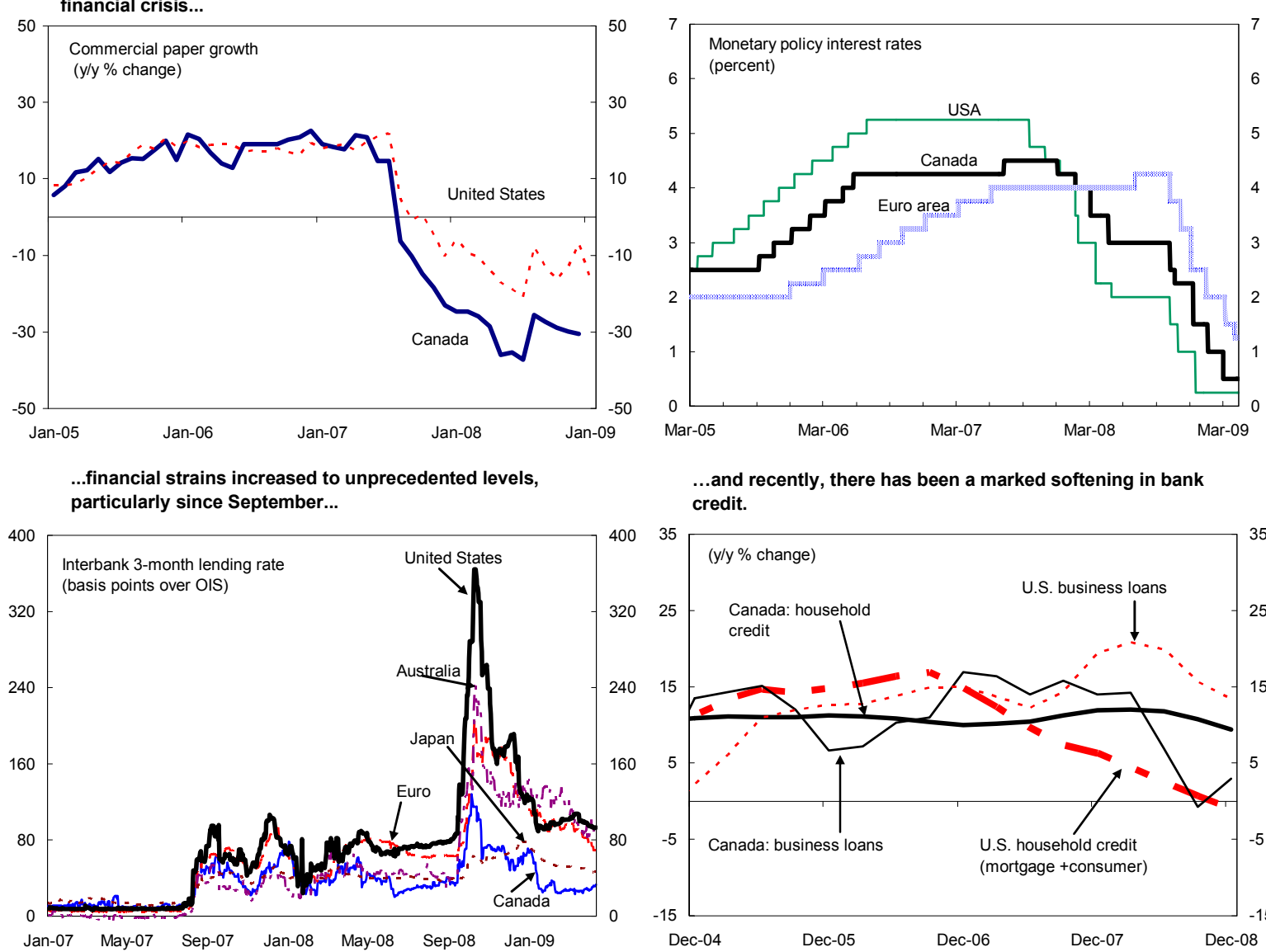

....and recently, there has been a marked softening in bank credit.

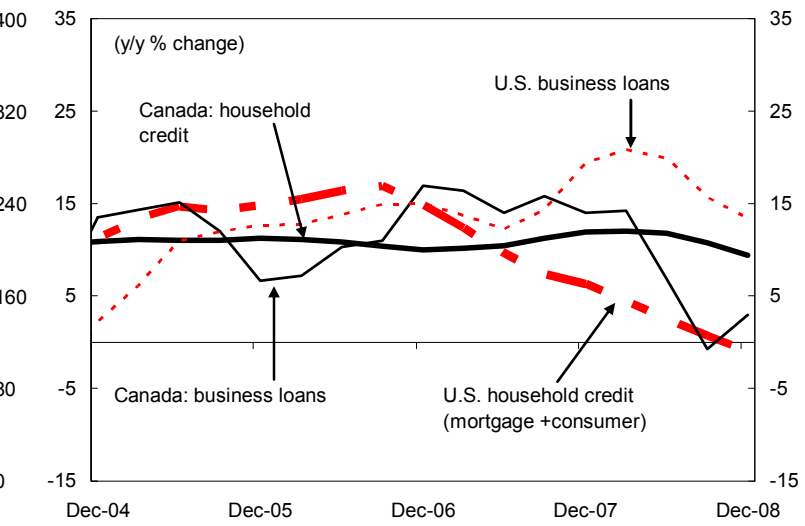

The crisis also translated into large stock losses...

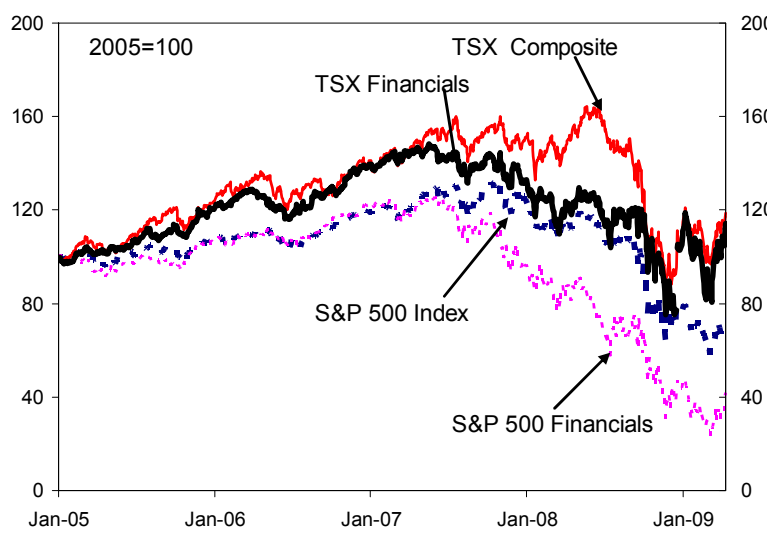

....and increased market volatility.

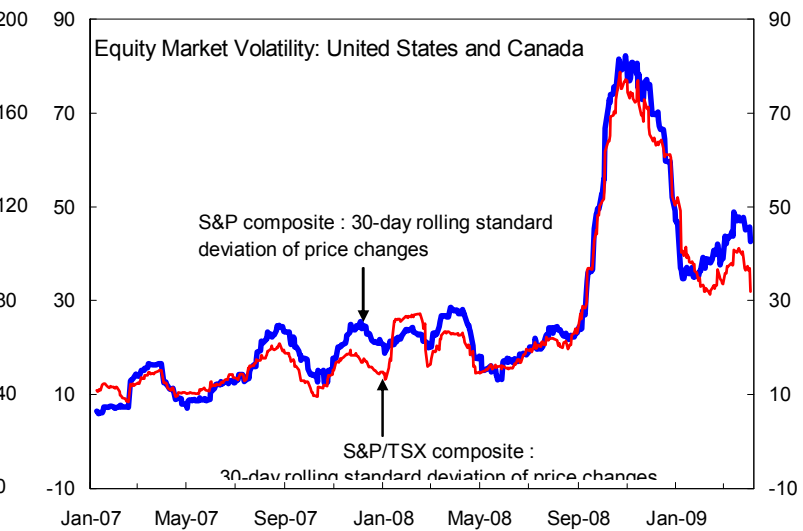

Sources: Bloomberg; Haver Analytics; DataStream Advanced; Markit; and staff estimates. 
Figure 5. Canada: Resilience of the Banking Sector So Far

CDS spreads are lower than those on U.S. banks...

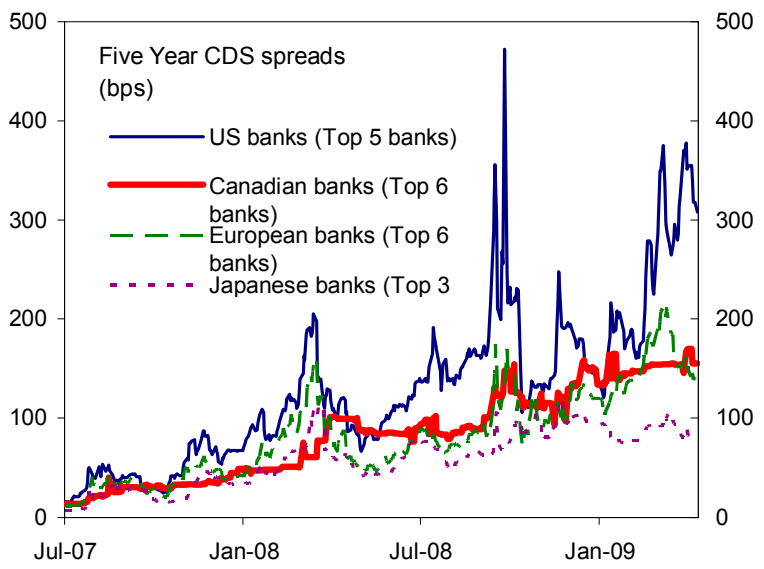

... while profitability rates are higher.

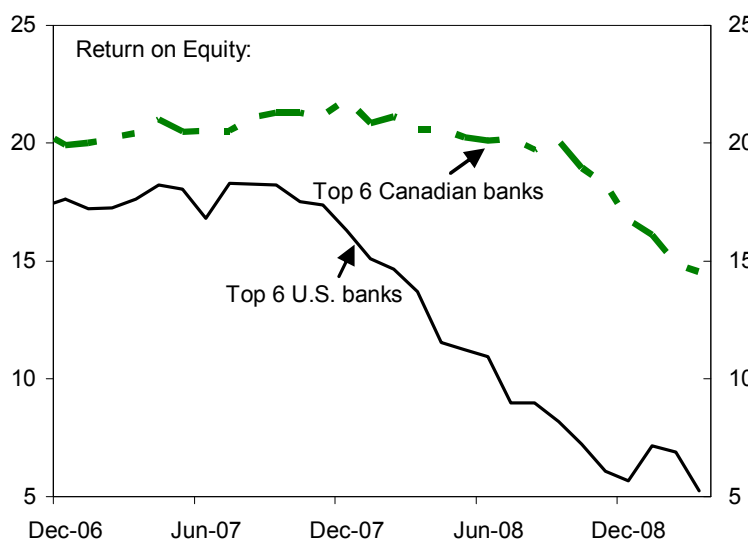

...and to the rest of the world...

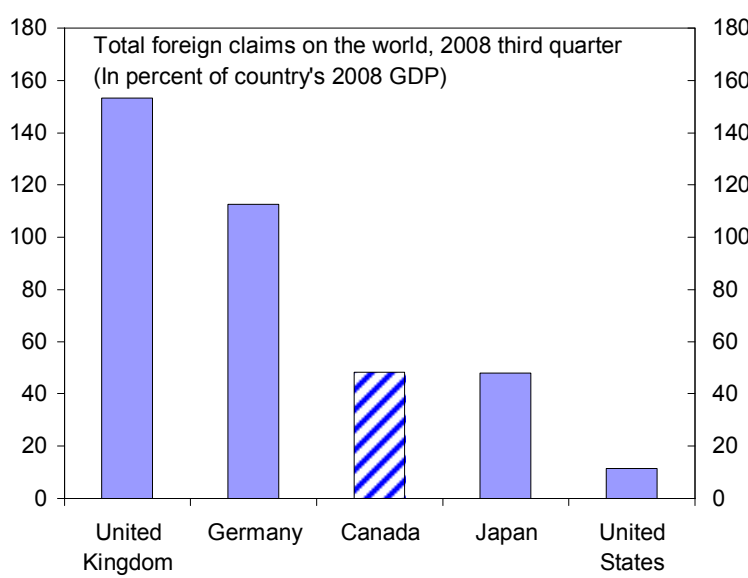

... as are equity-implied default probabilities...

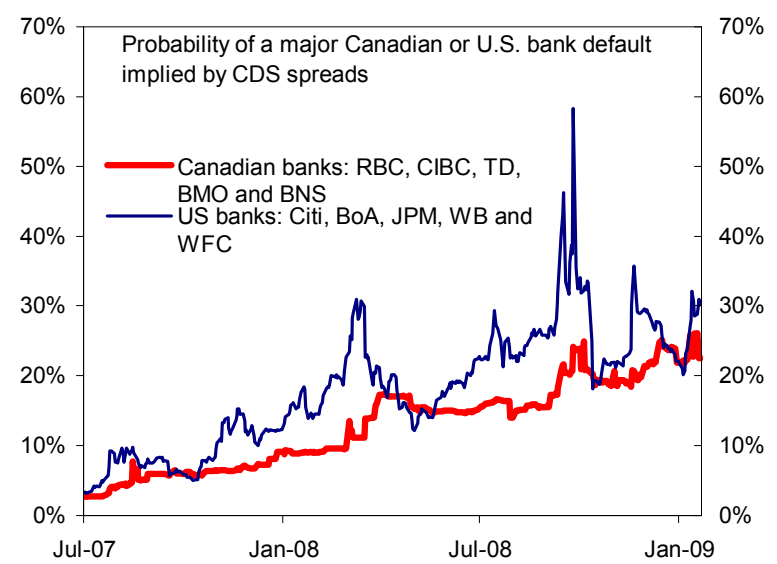

This relative resilience reflects limited exposure to the United States...

2560

U.S.: Foreign claims by nationality

(In percent of country's GDP)

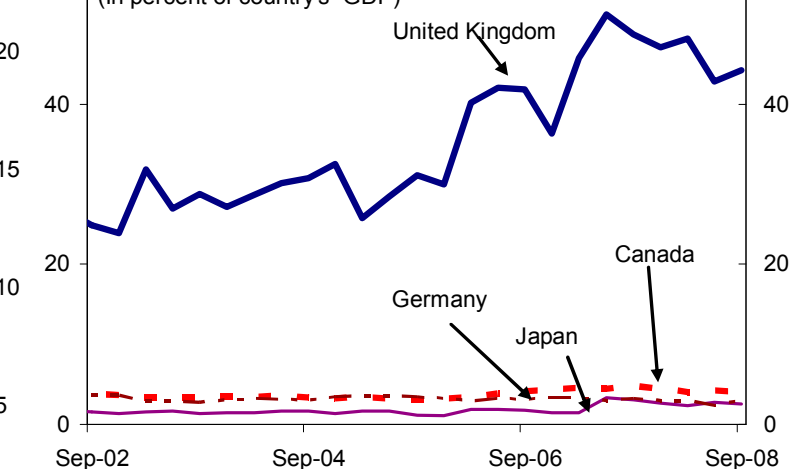

...and greater reliance on retail depository funding.

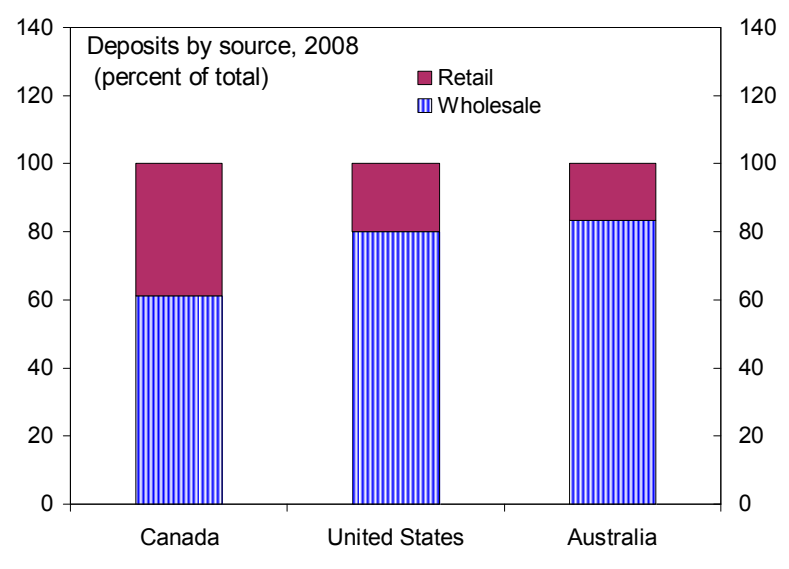

Sources: Authorities; Bank of Canada; Bloomberg; Haver Analytics; Bank of International Settlements; Markit; FDIC; Australian Prudential Regulation Authority; Reserve Bank of Australia; and Fund staff estimates. 
Figure 6. Canada: Impact of the Crisis on Non-Bank Financial Sector

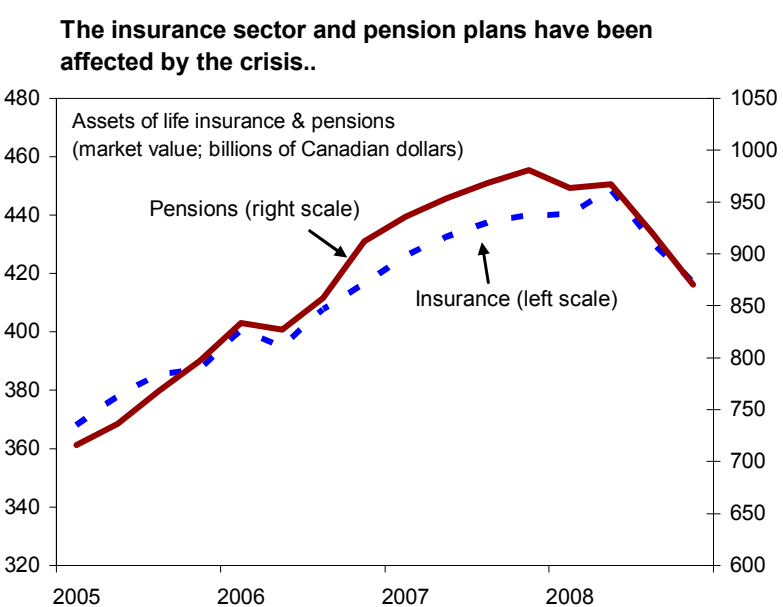

Equity- implied CDS spreads have gone up....

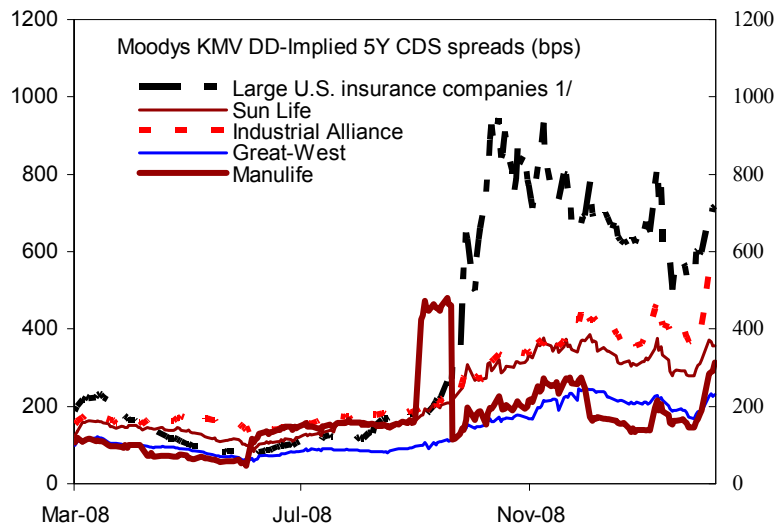

....and so do other profitability measures.

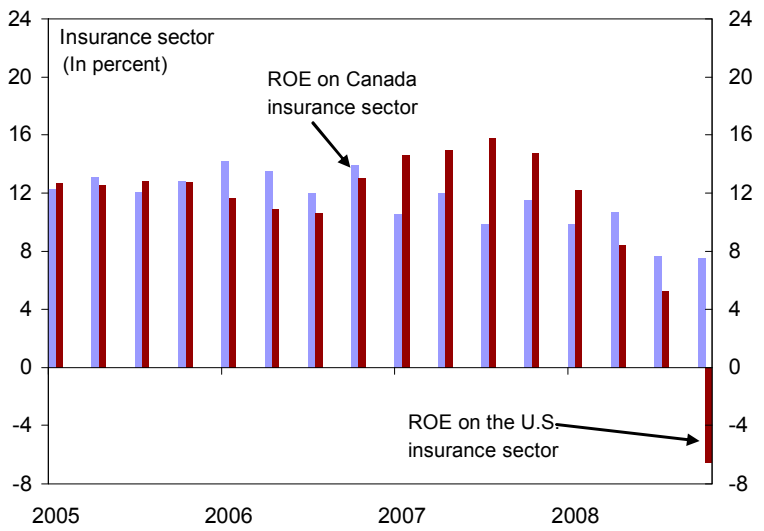

...partly reflecting the collapse of U.S. conglomerates.

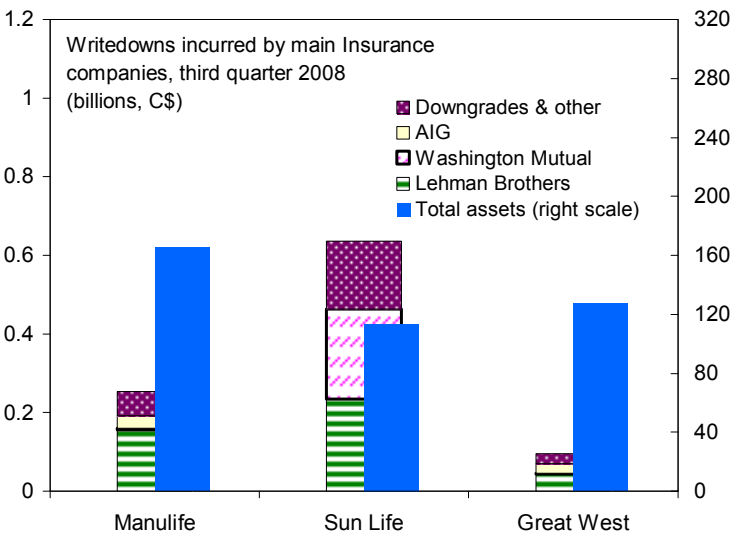

...although, stock prices in Canada's insurance sector remain stronger than in the U.S....

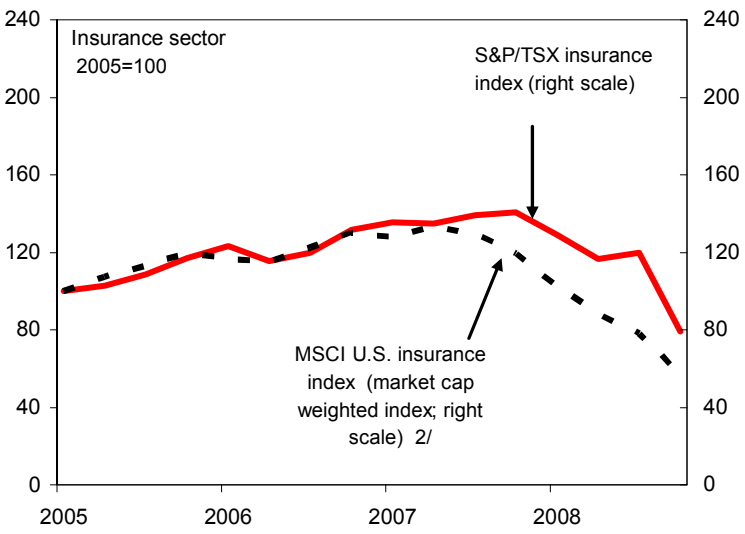

The decline in global equity prices has also led to record redemptions of mutual funds.

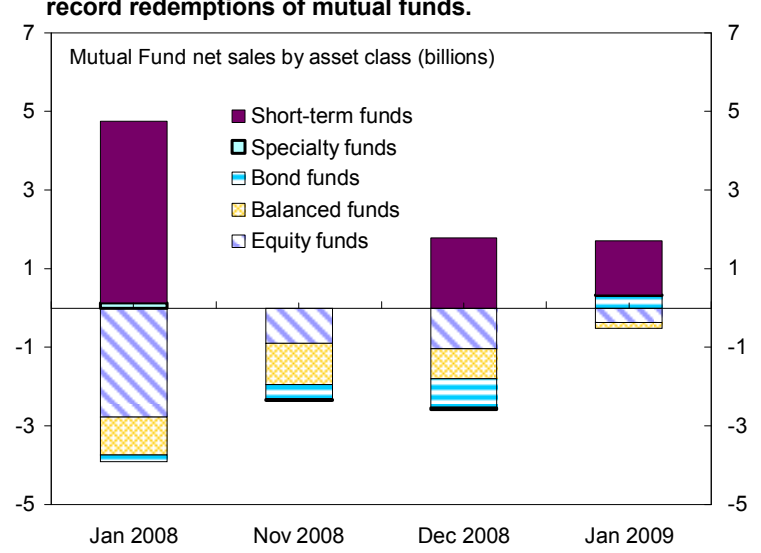

Sources: Bank of Canada; Office of Superintendent of Financial Institutions Canada; Insurance companies quarterly reports; Bloomberg; Haver Analytics; The Investment Funds Institute of Canada; and Fund staff estimates.

1/ Average of Metlife and Prudential.

2/ The MSCI U.S. insurance index is a market cap weighted index which measures price appreciation of stocks in this industry group. 

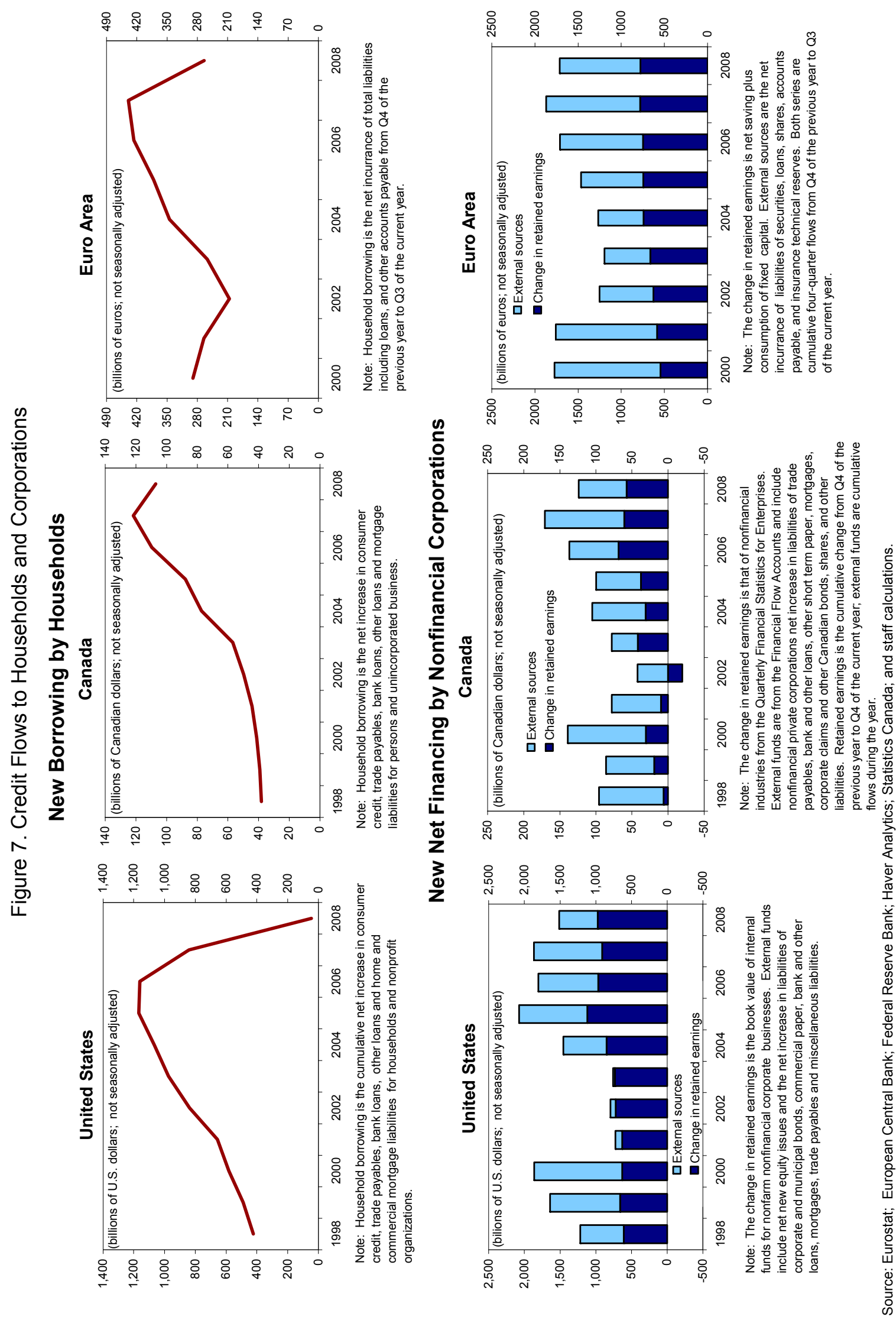
Figure 8. Canada: Risks to Households from Declining Income Growth

With declining real income growth...

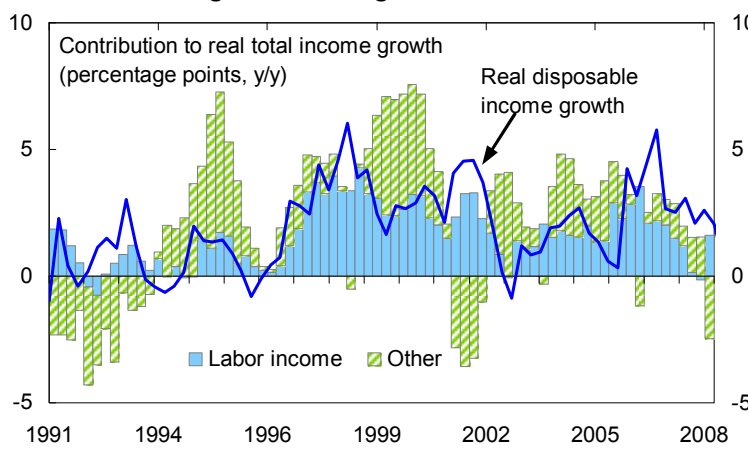

...household debt is at historical highs...

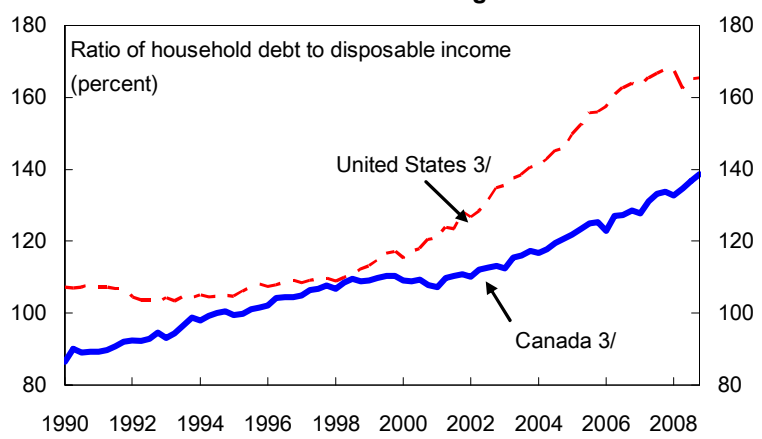

$\begin{array}{lllllllll}1992 & 1994 & 1996 & 1998 & 2000 & 2002 & 2004 & 2006 & 2008\end{array}$

The recession has further exacerbated consumer bankruptcies...

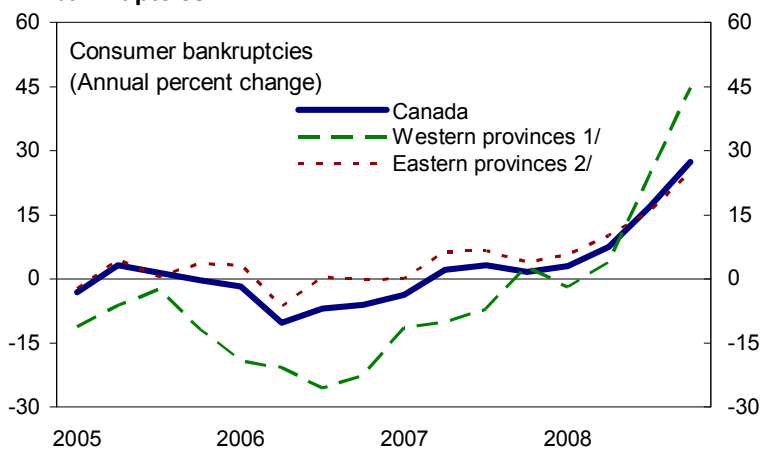

...raise risks of weaker consumption...

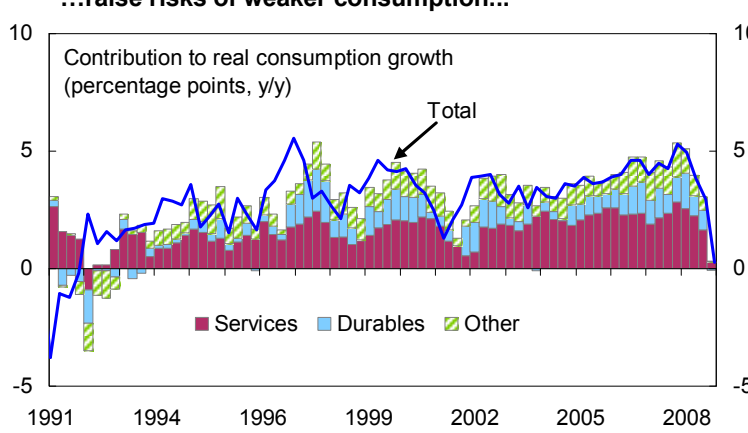

Source: Haver Analytics; Finance Canada; and staff estimates.

$1 /$ Includes Alberta and British Columbia.

2/ Includes Quebec and Ontario.

3/ Household debt includes liabilities of households, nonprofit organizations, and nonfarm noncorporate business sector. ...and falling saving rates...

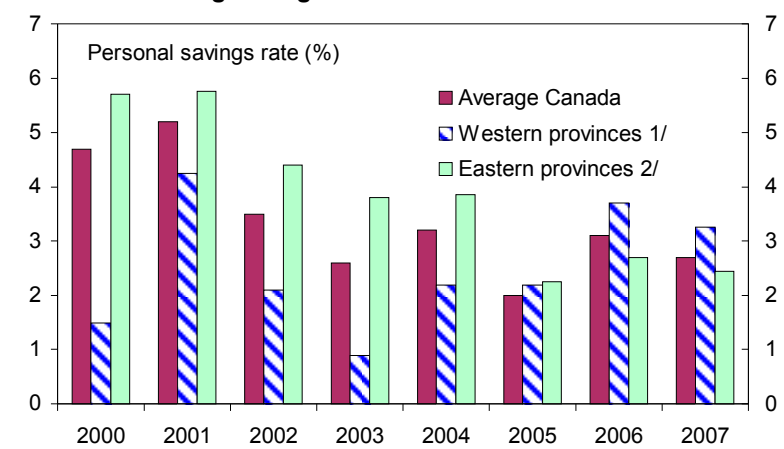

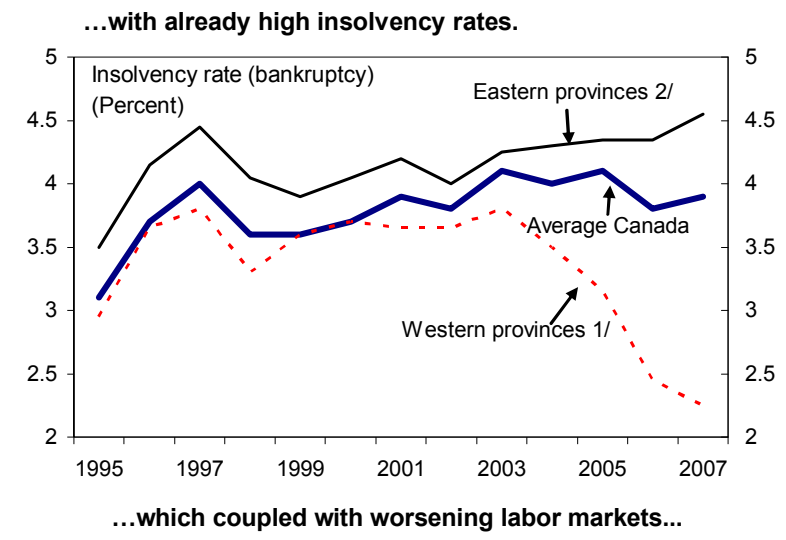
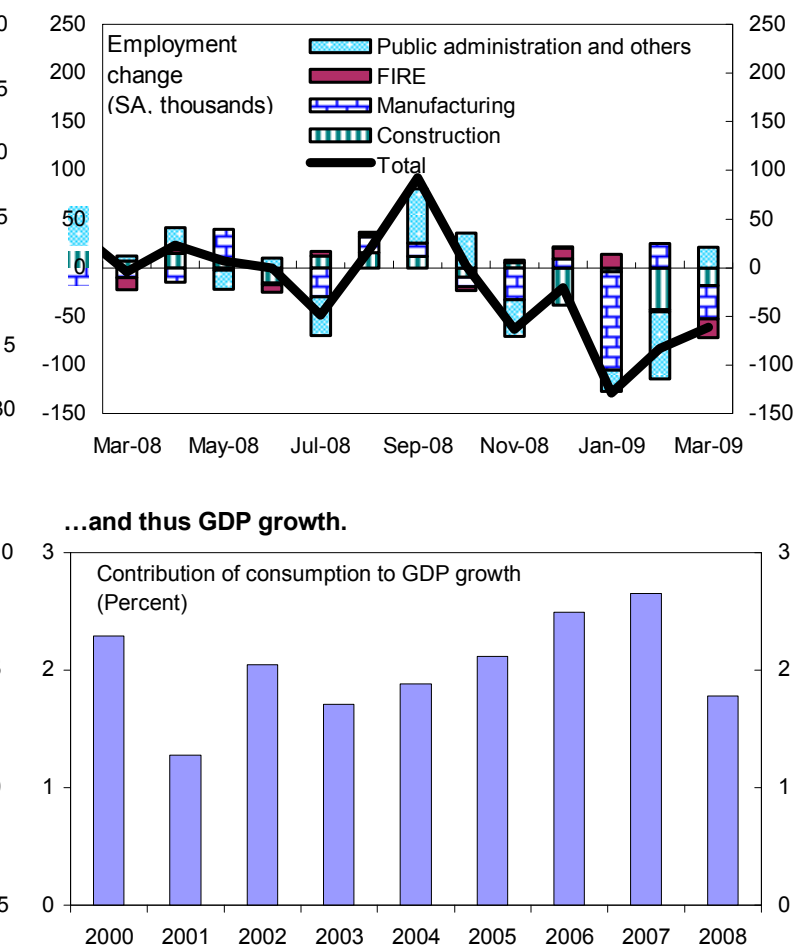
Figure 9. Canada: Risk to Households from a Softening Housing Market

\section{House prices have appreciated as much as in the United States.}

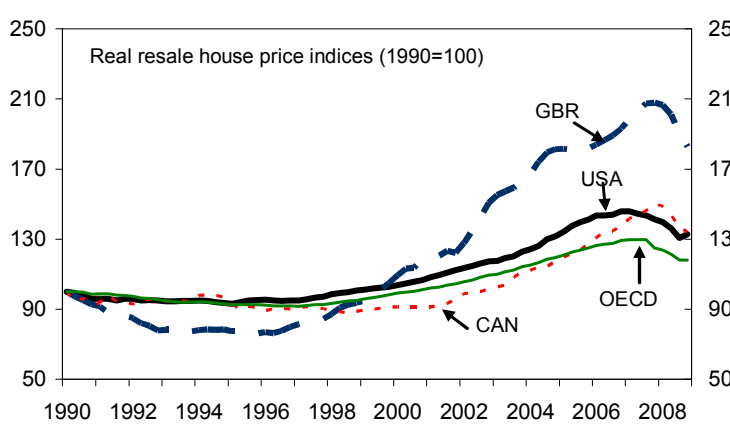

Securization is very limited in the mortgage market...

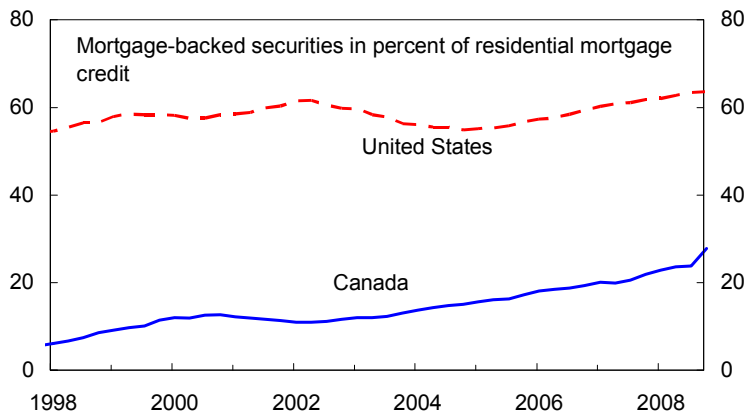

However, the Canadian housing market has started to exhibit strains on demand...
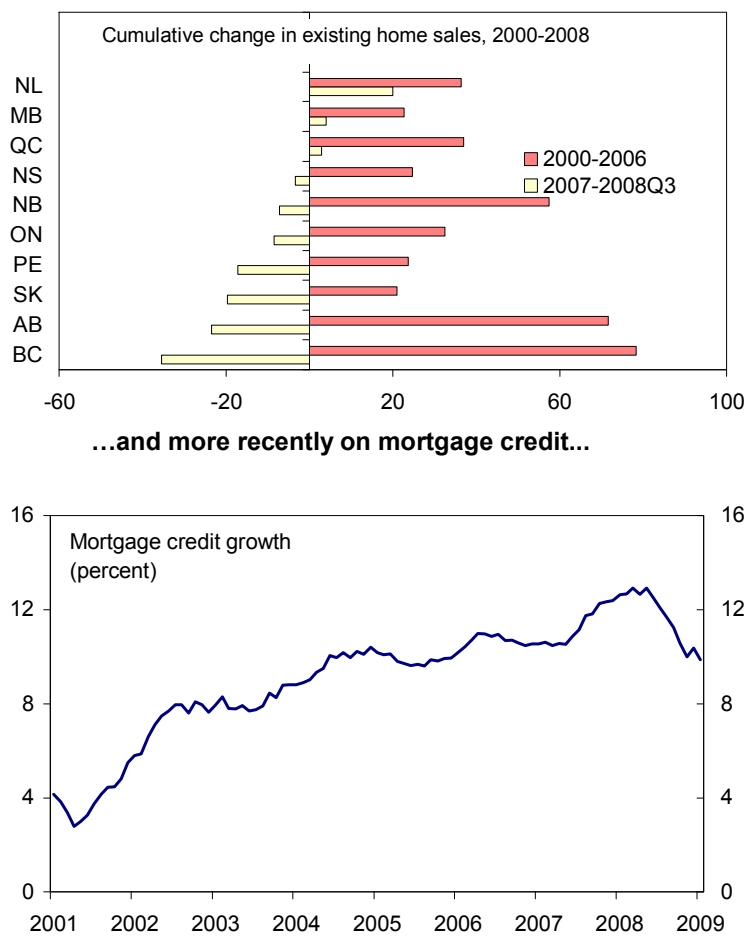

Although housing inventory has not risen as much as in the United States.

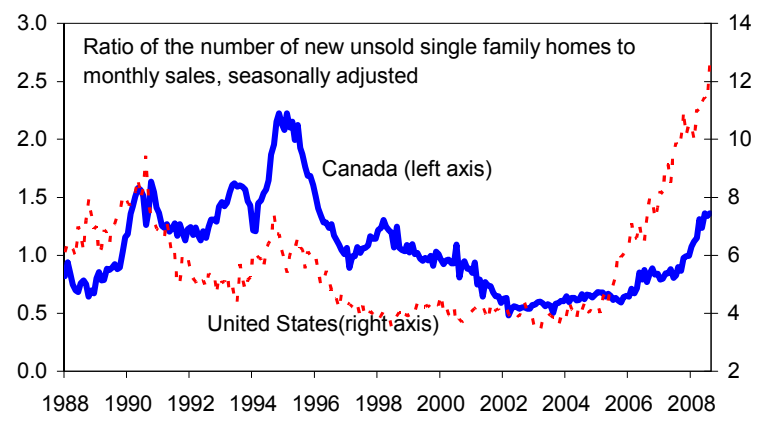

..and most mortgages are originated by banks.

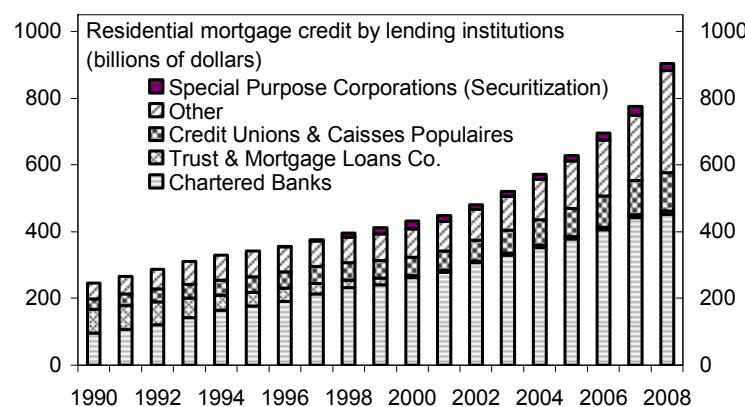

...as well as on supply...

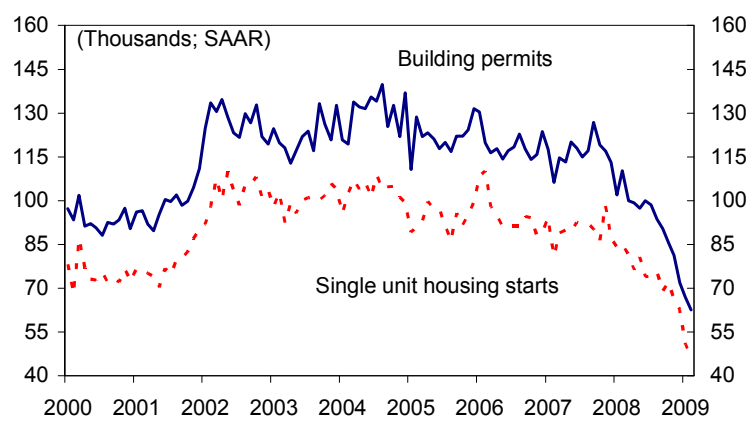

...which coupled with declining equity prices would affect household wealth.

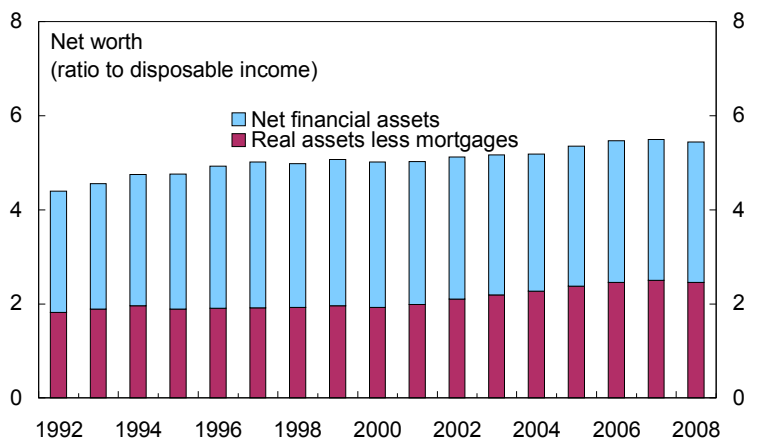

Sources: Bank of Canada; Canada Mortgage and Housing Corporation; Canadian Real Estate Association; Haver Analytics; Finance Canada; OECD; and IMF staff calculations. 
Figure 10. Canada: The Impact of the Crisis on the Corporate Sector

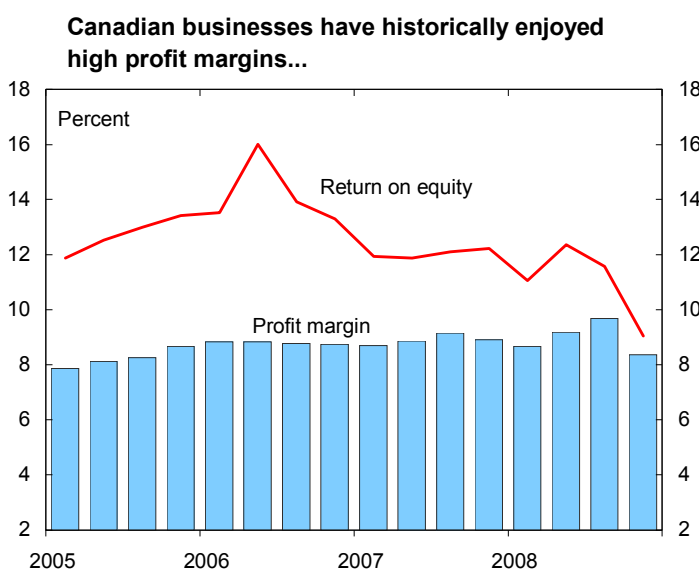

...and strong balance sheets.

However, bank lending standards for business borrowing have sharply tightened in recent months...
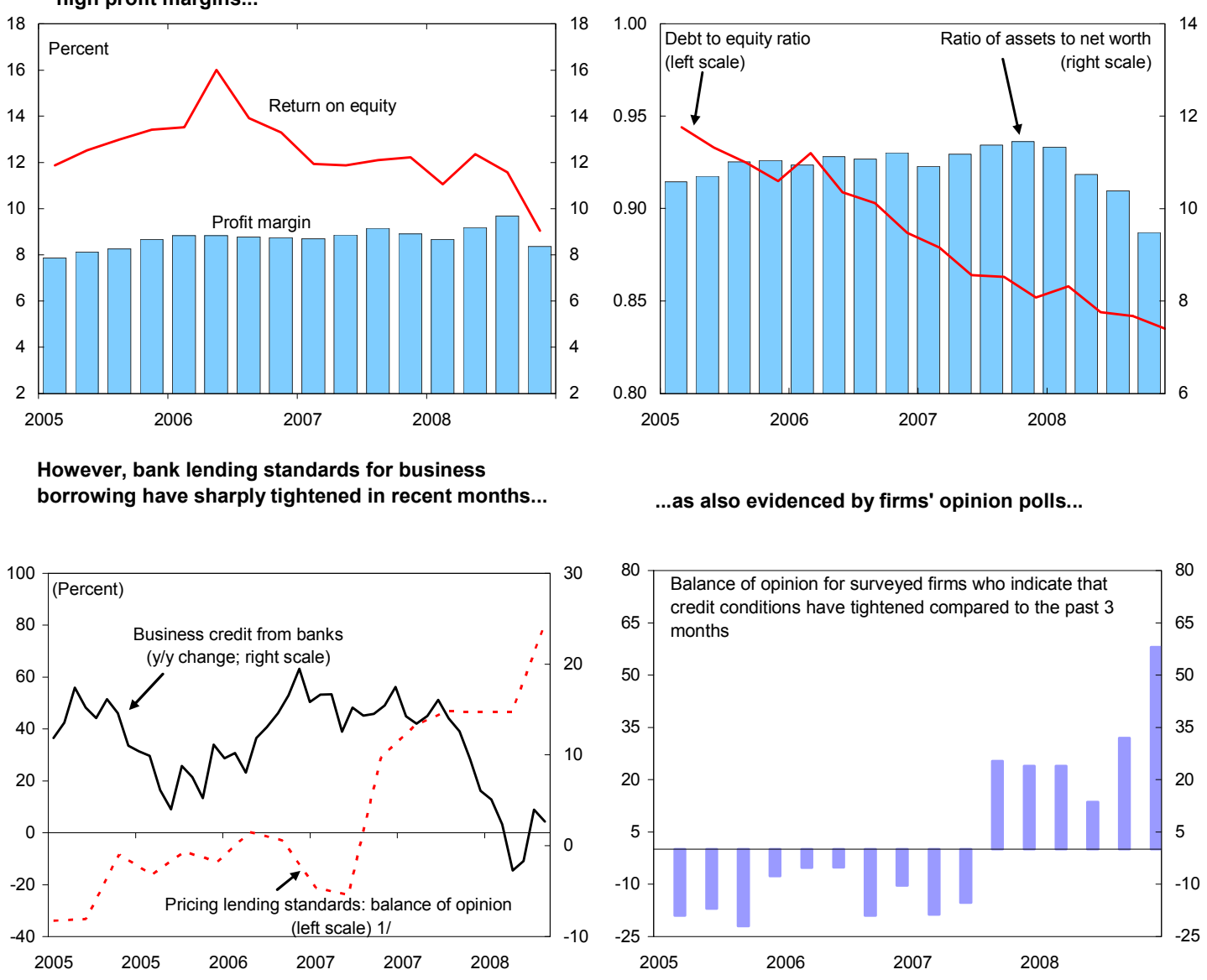

...as also evidenced by firms' opinion polls...

...while issuance of corporate paper has also slumped...

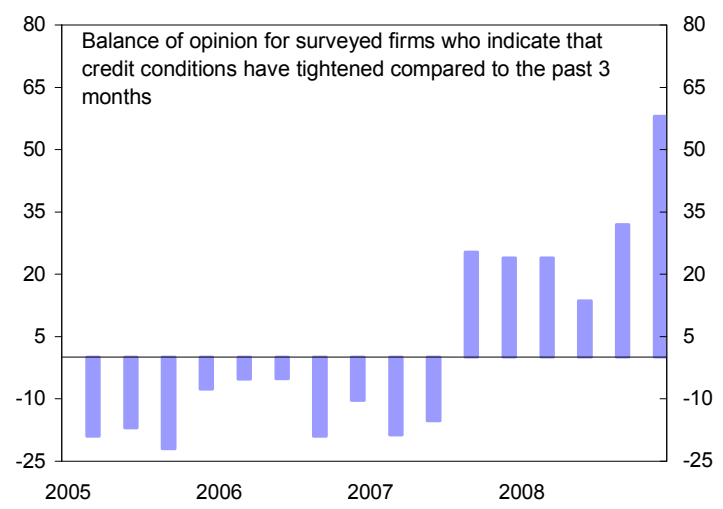

....as have firms' expectation of future sales growth.
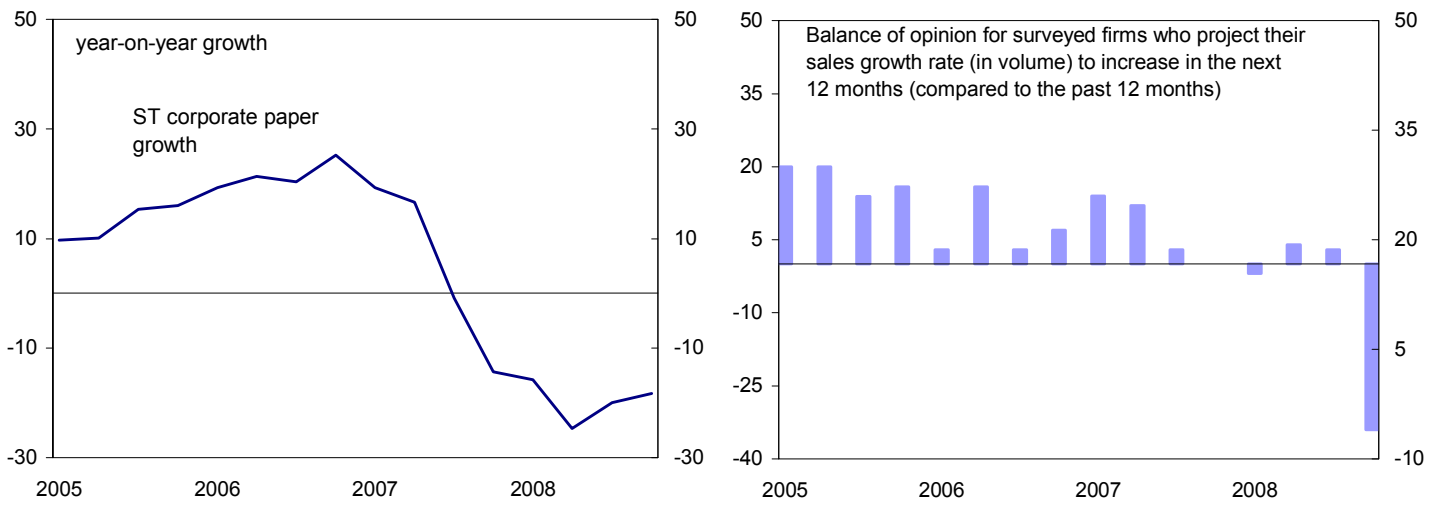

Sources: Haver Analytics; Thomson One Analytics; Canadian Federation of Independent Business; and IMF staff calculations. $1 /$ The balance of opinion is calculated as the weighted percentage of surveyed financial institutions reporting tightened credit conditions minus the weighted percentage reporting eased credit conditions. The sample includes lending to small business, commercial, and corporate sector. 


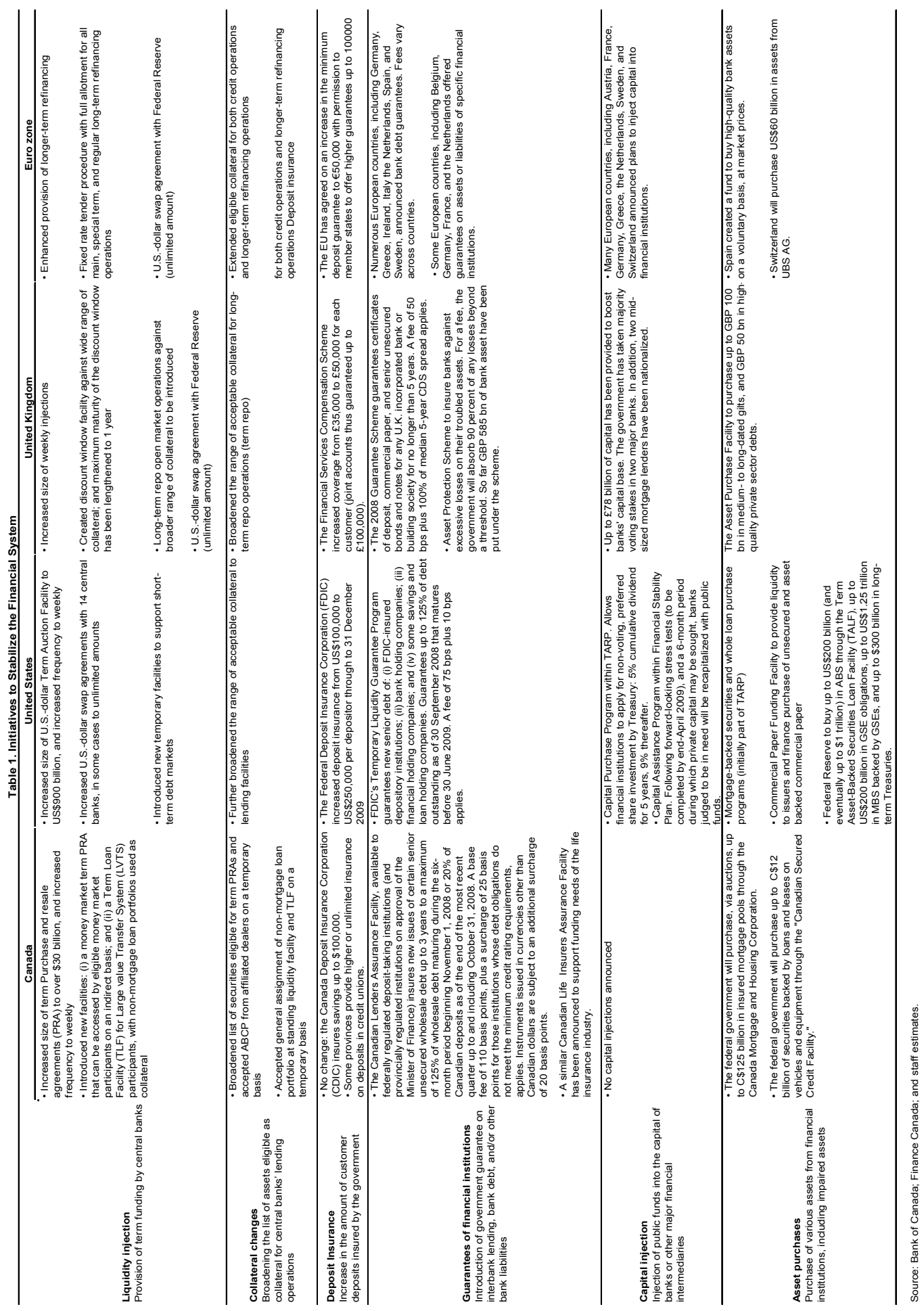


Table 2. Canada: Selected Economic Indicators

(In percent change at annual rates and seasonally adjusted, unless otherwise indicated)

\begin{tabular}{|c|c|c|c|c|c|c|c|c|c|c|c|c|}
\hline & & & & & \multicolumn{8}{|c|}{ Projections } \\
\hline & \multicolumn{4}{|c|}{2008} & \multicolumn{4}{|c|}{2009} & \multicolumn{4}{|c|}{2010} \\
\hline & Q1 & Q2 & Q3 & $\overline{Q 4}$ & Q1 & Q2 & Q3 & $\overline{Q 4}$ & Q1 & Q2 & Q3 & Q4 \\
\hline \multicolumn{13}{|l|}{ NA in constant prices } \\
\hline Real GDP & -0.9 & 0.6 & 0.9 & -3.4 & -7.7 & -1.6 & 0.6 & 1.1 & 1.4 & 1.6 & 1.9 & 1.9 \\
\hline Net exports $1 /$ & 0.9 & -2.3 & 0.0 & 1.8 & -1.0 & -0.6 & -0.5 & -0.1 & 0.0 & 0.2 & 0.3 & 0.3 \\
\hline Total domestic demand & -2.0 & 2.8 & 0.8 & -5.4 & -6.7 & -1.0 & 1.1 & 1.2 & 1.4 & 1.4 & 1.6 & 1.5 \\
\hline Final domestic demand & 1.8 & 1.3 & 0.5 & -4.9 & -6.3 & -0.8 & 1.2 & 1.3 & 1.4 & 1.4 & 1.7 & 1.6 \\
\hline Private consumption & 2.4 & 1.4 & 0.6 & -3.3 & -5.3 & -1.0 & 0.3 & 0.4 & 0.8 & 1.1 & 1.7 & 1.6 \\
\hline Public consumption & 1.5 & 3.9 & -0.2 & 2.8 & 1.5 & 2.3 & 2.6 & 3.5 & 3.3 & 2.5 & 1.4 & 1.3 \\
\hline Private fixed domestic investment & -0.5 & -1.8 & 0.8 & -17.6 & -18.8 & -5.7 & -3.0 & -1.7 & 0.7 & 1.0 & 1.5 & 1.5 \\
\hline Machinery and equipment & 0.4 & -3.6 & -2.4 & -26.8 & -24.2 & -5.0 & -1.0 & -0.7 & 0.9 & 1.1 & 1.3 & 1.4 \\
\hline Residential construction & -5.6 & -4.6 & -2.2 & -22.1 & -23.7 & -9.0 & -6.0 & -4.0 & 0.7 & 1.0 & 1.6 & 1.6 \\
\hline Private investment (in percent of GDP) & 19.5 & 19.1 & 19.3 & 19.6 & 19.1 & 18.9 & 18.7 & 18.5 & 18.4 & 18.3 & 18.3 & 18.2 \\
\hline Public investment & 7.6 & 4.2 & 2.7 & 4.3 & 7.8 & 10.8 & 33.2 & 17.6 & 1.8 & 2.0 & 3.4 & 3.4 \\
\hline Change in inventories $1 /$ & -3.4 & 1.3 & 0.1 & -0.8 & -0.4 & -0.2 & -0.1 & -0.1 & 0.0 & 0.0 & 0.0 & 0.0 \\
\hline GDP (current prices) & 4.9 & 10.7 & 3.6 & -13.4 & -9.8 & 0.1 & 0.8 & 2.3 & 3.2 & 4.0 & 0.9 & 5.0 \\
\hline \multicolumn{13}{|l|}{ Employment and inflation } \\
\hline Unemployment rate (percent) & 5.9 & 6.1 & 6.2 & 6.4 & 8.1 & 8.9 & 9.1 & 9.3 & 9.3 & 9.3 & 9.2 & 9.2 \\
\hline Employment & 1.9 & 0.8 & -0.1 & 0.5 & -7.3 & -3.8 & -1.0 & 0.0 & 1.8 & 2.1 & 2.3 & 2.3 \\
\hline CPI inflation $(y / y)$ & 1.9 & 2.3 & 3.4 & 1.9 & 1.3 & 0.1 & -1.0 & -0.2 & 0.1 & 0.4 & 0.7 & 0.9 \\
\hline CPI inflation ( $q / q$, annualized) & 2.2 & 4.2 & 4.6 & -3.1 & -0.5 & -0.6 & 0.0 & 0.3 & 0.6 & 0.8 & 1.0 & 1.2 \\
\hline Core CPI inflation (y/y) & 1.4 & 1.5 & 1.6 & 2.2 & 2.0 & 1.5 & 1.1 & 0.6 & 0.5 & 0.4 & 0.4 & 0.4 \\
\hline Core $\mathrm{CPI}$ inflation ( $\mathrm{q} / \mathrm{q}$, annualized) & 2.0 & 2.6 & 1.9 & 2.4 & 1.0 & 0.6 & 0.5 & 0.4 & 0.3 & 0.3 & 0.4 & 0.5 \\
\hline GDP deflator & 5.9 & 10.1 & 2.6 & -10.3 & -2.2 & 1.7 & 0.2 & 1.2 & 1.8 & 2.4 & -1.0 & 3.0 \\
\hline Potential output growth & 2.2 & 2.1 & 2.0 & 1.7 & 1.6 & 1.6 & 1.6 & 1.6 & 1.6 & 1.6 & 1.6 & 1.6 \\
\hline Output gap (in percent of potential output) & 0.6 & 0.2 & -0.1 & -1.4 & -3.7 & -4.5 & -4.7 & -4.8 & -4.9 & -4.8 & -4.8 & -4.7 \\
\hline \multicolumn{13}{|l|}{ Interest rates 2 I } \\
\hline Three-month treasury bill (percent) & 3.1 & 2.6 & 2.4 & 1.6 & 0.8 & 0.4 & 0.4 & 0.4 & 0.4 & 0.5 & 0.7 & 0.9 \\
\hline Ten-year government bond yield (percent) & 3.7 & 3.7 & 3.6 & 3.4 & 2.9 & 2.7 & 2.6 & 2.6 & 2.6 & 2.7 & 2.9 & 3.0 \\
\hline \multicolumn{13}{|l|}{ External indicators } \\
\hline Current account balance (in percent of GDP) & 1.4 & 2.1 & 0.9 & -1.9 & -1.6 & -1.5 & -1.7 & -1.8 & -1.6 & -1.2 & -1.7 & -1.2 \\
\hline Merchandise trade balance (in percent of GDP) & 3.3 & 4.0 & 3.5 & 0.9 & 0.2 & 0.4 & 0.3 & 0.4 & 0.6 & 1.0 & 0.6 & 1.1 \\
\hline Export volume & -4.3 & -3.6 & -3.1 & -19.7 & -42.0 & -9.6 & -2.1 & 0.7 & 1.1 & 2.7 & 3.5 & 3.7 \\
\hline Import volume & -5.7 & 5.5 & -1.8 & -24.0 & -39.9 & -6.8 & 0.3 & 1.2 & 1.4 & 2.1 & 2.6 & 2.7 \\
\hline Balance on invisibles (in percent of GDP) & -1.9 & -1.9 & -2.6 & -2.8 & -1.9 & -1.9 & -2.0 & -2.2 & -2.2 & -2.2 & -2.3 & -2.3 \\
\hline Exchange rate (USD/C\$) 2/ & 1.00 & 0.99 & 0.96 & 0.82 & 0.80 & $\ldots$ & $\ldots$ & $\ldots$ & $\ldots$ & $\ldots$ & $\ldots$ & $\ldots$ \\
\hline Nominal effective exchange rate $(q / q) 2 /$ & -2.8 & -1.0 & -2.6 & -12.3 & $\ldots$ & $\ldots$ & $\ldots$ & $\ldots$ & $\ldots$ & $\ldots$ & $\ldots$ & $\ldots$ \\
\hline Real effective exchange rate $(q / q) 2 /$ & -3.5 & -0.9 & -2.6 & -11.4 & $\ldots$ & $\ldots$ & $\ldots$ & $\ldots$ & $\ldots$ & $\ldots$ & $\ldots$ & $\ldots$ \\
\hline Terms of trade $2 /$ & 9.9 & 15.4 & -6.3 & -31.5 & -7.0 & 5.2 & -1.0 & 2.0 & 3.4 & 5.5 & -6.6 & 7.0 \\
\hline \multicolumn{13}{|l|}{ Saving and investment (in percent of GDP) } \\
\hline Gross national saving & 23.8 & 24.8 & 24.7 & 21.8 & $\ldots$ & $\ldots$ & $\ldots$ & $\ldots$ & $\ldots$ & $\ldots$ & $\ldots$ & $\ldots$ \\
\hline General government & 3.5 & 4.1 & 4.2 & 2.8 & $\ldots$ & $\ldots$ & $\ldots$ & $\ldots$ & $\ldots$ & $\ldots$ & $\ldots$ & $\ldots$ \\
\hline Private & 20.2 & 20.6 & 20.5 & 19.0 & $\ldots$ & $\ldots$ & $\ldots$ & $\ldots$ & $\ldots$ & $\ldots$ & $\ldots$ & $\ldots$ \\
\hline Personal & 5.1 & 5.0 & 4.8 & 6.0 & $\ldots$ & $\ldots$ & $\ldots$ & $\ldots$ & $\ldots$ & $\ldots$ & $\ldots$ & $\ldots$ \\
\hline Business & 15.2 & 15.7 & 15.7 & 13.0 & $\ldots$ & $\ldots$ & $\ldots$ & $\ldots$ & $\ldots$ & $\ldots$ & $\ldots$ & $\ldots$ \\
\hline Gross domestic investment & 22.7 & 22.8 & 23.2 & 23.5 & $\ldots$ & $\ldots$ & $\ldots$ & $\ldots$ & $\ldots$ & $\ldots$ & $\ldots$ & $\ldots$ \\
\hline \multicolumn{13}{|l|}{ Memorandum item } \\
\hline Real GDP in United States & 0.9 & 2.8 & -0.5 & -6.3 & -6.0 & -0.3 & -0.1 & -2.3 & -1.7 & 1.7 & 3.1 & 2.7 \\
\hline
\end{tabular}


Table 2. Canada: Selected Economic Indicators (concluded)

\begin{tabular}{|c|c|c|c|c|c|c|c|c|c|}
\hline & \multirow[b]{2}{*}{2006} & \multirow[b]{2}{*}{2007} & \multirow[b]{2}{*}{2008} & \multicolumn{6}{|c|}{ Projections } \\
\hline & & & & 2009 & 2010 & 2011 & 2012 & 2013 & 2014 \\
\hline \multicolumn{10}{|l|}{ NA in constant prices } \\
\hline Real GDP & 3.1 & 2.7 & 0.5 & -2.6 & 1.2 & 2.5 & 3.9 & 3.4 & 2.5 \\
\hline Q4/Q4 & 2.2 & 2.8 & -0.7 & -2.0 & 1.7 & 3.1 & 4.1 & 3.0 & 2.2 \\
\hline Net exports $1 /$ & -1.3 & -1.5 & -1.9 & -0.5 & 0.0 & 0.5 & 0.3 & 0.5 & 0.5 \\
\hline Total domestic demand & 4.7 & 4.3 & 2.4 & -2.5 & 1.2 & 1.9 & 3.5 & 3.0 & 2.0 \\
\hline Final domestic demand & 4.8 & 4.2 & 2.5 & -2.3 & 1.3 & 1.9 & 3.5 & 3.0 & 2.0 \\
\hline Private consumption & 4.3 & 4.5 & 3.0 & -1.9 & 0.8 & 2.0 & 4.2 & 3.4 & 2.0 \\
\hline Public consumption & 3.8 & 3.7 & 3.4 & 2.1 & 2.7 & 1.9 & 2.0 & 2.1 & 2.2 \\
\hline Private fixed domestic investment & 7.1 & 3.4 & 0.0 & -9.9 & -0.4 & 2.4 & 3.5 & 2.9 & 2.1 \\
\hline Machinery and equipment & 10.6 & 7.1 & 2.0 & -13.5 & 0.1 & 3.0 & 4.2 & 3.3 & 2.2 \\
\hline Residential construction & 2.2 & 3.0 & -2.9 & -13.8 & -1.5 & 2.2 & 3.0 & 2.5 & 2.0 \\
\hline Private investment (in percent of GDP) & 19.5 & 19.6 & 19.4 & 18.8 & 18.3 & 18.2 & 18.1 & 18.0 & 18.0 \\
\hline Public investment & 6.7 & 7.8 & 5.7 & 10.4 & 8.9 & -1.8 & 2.6 & 2.5 & 2.4 \\
\hline Change in inventories $1 /$ & -0.1 & 0.1 & -0.1 & -0.1 & -0.1 & 0.0 & 0.0 & 0.0 & 0.0 \\
\hline GDP (current prices) & 5.7 & 5.9 & 4.4 & -3.9 & 2.5 & 4.0 & 6.0 & 5.7 & 4.8 \\
\hline \multicolumn{10}{|l|}{ Employment and inflation } \\
\hline Unemployment rate (percent) & 6.3 & 6.0 & 6.2 & 8.9 & 9.2 & 8.4 & 6.6 & 6.2 & 6.1 \\
\hline Employment & 1.9 & 2.3 & 1.5 & -2.6 & 0.9 & 2.6 & 3.6 & 1.9 & 1.5 \\
\hline CPI inflation & 2.0 & 2.1 & 2.4 & 0.0 & 0.5 & 1.4 & 2.1 & 2.4 & 2.1 \\
\hline Core CPI inflation (y/y) & 1.9 & 2.1 & 1.7 & 1.3 & 0.4 & 0.8 & 1.7 & 2.2 & 2.0 \\
\hline GDP deflator & 2.5 & 3.1 & 3.8 & -1.3 & 1.3 & 1.5 & 2.0 & 2.2 & 2.3 \\
\hline Potential output growth & 2.3 & 2.3 & 2.2 & 1.7 & 1.6 & 1.6 & 1.7 & 1.9 & 2.0 \\
\hline Output gap (in percent of potential output) & 1.1 & 1.5 & -0.2 & -4.4 & -4.8 & -4.0 & -2.0 & -0.5 & 0.0 \\
\hline \multicolumn{10}{|l|}{$\begin{array}{l}\text { Indicators of fiscal policies } \\
\text { (NA basis, in percent of GDP) }\end{array}$} \\
\hline Federal fiscal balance & 0.7 & 1.0 & 0.2 & -2.0 & -2.5 & -1.6 & -0.9 & -0.4 & 0.1 \\
\hline Provincial fiscal balance $3 /$ & -0.2 & -0.3 & -0.4 & -1.4 & -1.3 & -1.2 & -0.7 & -0.3 & 0.1 \\
\hline General government fiscal balance 3/ & 1.3 & 1.4 & 0.4 & -3.1 & -3.5 & -2.4 & -1.3 & -0.4 & 0.4 \\
\hline General government net debt & 26.4 & 23.2 & 21.9 & 25.9 & 28.7 & 30.0 & 29.6 & 28.5 & 26.8 \\
\hline Three-month treasury bill (percent) & 4.0 & 4.2 & 2.4 & 0.5 & 0.6 & 2.6 & 4.3 & 4.8 & 4.8 \\
\hline Ten-year government bond yield (percent) & 4.2 & 4.3 & 3.6 & 2.7 & 2.8 & 4.2 & 5.2 & 5.5 & 5.5 \\
\hline \multicolumn{10}{|l|}{ External indicators } \\
\hline Current account balance (in percent of GDP) & 1.4 & 0.9 & 0.6 & -1.7 & -1.4 & -0.7 & -0.3 & 0.2 & 0.9 \\
\hline Merchandise trade balance (in percent of GDP) & 3.4 & 3.1 & 2.9 & 0.3 & 0.8 & 1.4 & 1.8 & 2.1 & 2.7 \\
\hline Export volume & 0.9 & 1.4 & -5.0 & -18.5 & 0.6 & 4.3 & 5.3 & 4.8 & 4.2 \\
\hline Import volume & 5.0 & 5.4 & 1.0 & -17.3 & 1.1 & 2.5 & 4.6 & 3.7 & 2.9 \\
\hline Balance on invisibles (in percent of GDP) & -2.0 & -2.2 & -2.3 & -2.0 & -2.2 & -2.2 & -2.1 & -1.9 & -1.8 \\
\hline Terms of trade & 0.6 & 3.0 & 4.7 & -7.7 & 2.2 & 0.5 & 0.4 & 0.1 & 0.9 \\
\hline \multicolumn{10}{|l|}{ Saving and investment (in percent of GDP) } \\
\hline Gross national saving & 24.3 & 24.1 & 23.7 & 21.4 & 21.3 & 21.7 & 22.0 & 22.3 & 23.0 \\
\hline General government & 4.3 & 4.5 & 3.7 & 0.8 & 0.7 & 1.6 & 2.6 & 3.5 & 4.3 \\
\hline Private & 20.0 & 19.7 & 20.0 & 20.5 & 20.6 & 20.1 & 19.4 & 18.8 & 18.6 \\
\hline Personal & 4.7 & 4.5 & 5.2 & 7.0 & 7.3 & 6.6 & 5.6 & 5.0 & 4.7 \\
\hline Business & 15.4 & 14.7 & 14.9 & 13.5 & 13.3 & 13.5 & 13.8 & 13.8 & 13.9 \\
\hline Gross domestic investment & 22.9 & 23.3 & 23.0 & 23.0 & 22.7 & 22.5 & 22.3 & 22.2 & 22.1 \\
\hline $\begin{array}{l}\text { Personal Savings (in percent of DI) } \\
\text { Memorandum item }\end{array}$ & 3.1 & 2.7 & 3.7 & 5.9 & 6.1 & 5.4 & 4.6 & 4.2 & 4.1 \\
\hline Real GDP in United States & 2.8 & 2.0 & 1.1 & -2.8 & 0.0 & 3.6 & 3.7 & 3.3 & 2.4 \\
\hline
\end{tabular}

Sources: Haver Analytics; and Fund staff estimates.

$1 /$ Contribution to growth.

2/ Not seasonally adjusted.

$3 /$ Includes local governments and hospitals. 
Table 3. Canada: Indicators of Economic Performance 1/

\begin{tabular}{|c|c|c|c|c|c|c|c|c|c|c|}
\hline & & \multirow{2}{*}{$\begin{array}{c}\text { Average } \\
1997-2006\end{array}$} & \multirow[b]{2}{*}{2003} & \multirow[b]{2}{*}{2004} & \multirow[b]{2}{*}{2005} & \multirow[b]{2}{*}{2006} & \multirow[b]{2}{*}{2007} & \multirow[b]{2}{*}{2008} & \multicolumn{2}{|c|}{ Proj. } \\
\hline & & & & & & & & & 2009 & 2010 \\
\hline & \multicolumn{10}{|c|}{ (In annual percent change) } \\
\hline \multirow[t]{7}{*}{ Per capita real GDP } & Canada & 2.5 & 0.9 & 2.1 & 1.9 & 2.1 & 1.6 & -0.7 & -4.1 & -0.4 \\
\hline & United States & 2.0 & 1.6 & 2.7 & 2.0 & 1.8 & 1.0 & 0.2 & -3.8 & -1.0 \\
\hline & Euro Area & 1.8 & 0.2 & 1.5 & 1.2 & 2.4 & 2.0 & 0.3 & -4.7 & -0.8 \\
\hline & Japan & 0.9 & 1.2 & 2.7 & 1.9 & 2.0 & 2.4 & -0.6 & -6.2 & -0.1 \\
\hline & United Kingdom & 2.5 & 2.4 & 2.3 & 1.4 & 2.2 & 2.5 & 0.4 & -4.3 & -1.6 \\
\hline & Australia & 2.3 & 0.9 & 1.3 & 0.7 & 0.7 & 1.2 & 0.4 & -1.0 & -0.2 \\
\hline & New Zealand & 1.9 & 2.2 & 3.0 & 1.7 & 0.7 & 2.1 & -0.7 & -3.0 & -0.5 \\
\hline \multirow[t]{7}{*}{ Real GDP } & Canada & 3.5 & 1.9 & 3.1 & 2.9 & 3.1 & 2.7 & 0.5 & -2.6 & 1.2 \\
\hline & United States & 3.1 & 2.5 & 3.6 & 2.9 & 2.8 & 2.0 & 1.1 & -2.8 & 0.0 \\
\hline & Euro Area & 2.3 & 0.8 & 2.2 & 1.7 & 2.9 & 2.7 & 0.9 & -4.2 & -0.4 \\
\hline & Japan & 1.1 & 1.4 & 2.7 & 1.9 & 2.0 & 2.4 & -0.6 & -6.2 & -0.2 \\
\hline & United Kingdom & 2.9 & 2.8 & 2.8 & 2.1 & 2.8 & 3.0 & 0.7 & -4.1 & -0.4 \\
\hline & Australia & 3.6 & 3.0 & 3.8 & 2.8 & 2.8 & 4.0 & 2.1 & -0.7 & 0.8 \\
\hline & New Zealand & 3.1 & 4.1 & 4.5 & 2.8 & 1.9 & 3.2 & 0.3 & -2.0 & 0.6 \\
\hline \multirow{7}{*}{$\begin{array}{l}\text { Real domestic } \\
\text { demand }\end{array}$} & Canada & 4.0 & 4.6 & 4.2 & 4.8 & 4.7 & 4.3 & 2.4 & -2.5 & 1.2 \\
\hline & United States & 3.5 & 2.8 & 4.1 & 3.0 & 2.6 & 1.4 & -0.3 & -2.7 & 0.3 \\
\hline & Euro Area & 2.2 & 1.4 & 1.9 & 1.9 & 2.8 & 2.4 & 0.9 & -2.9 & -0.6 \\
\hline & Japan & 0.7 & 0.8 & 1.9 & 1.7 & 1.2 & 1.3 & -0.8 & -2.9 & -0.4 \\
\hline & United Kingdom & 3.4 & 2.9 & 3.4 & 1.9 & 2.6 & 3.5 & 0.6 & -4.8 & -1.0 \\
\hline & Australia & 4.4 & 5.6 & 5.9 & 4.3 & 3.1 & 5.9 & 3.5 & -0.7 & 1.2 \\
\hline & New Zealand & 3.7 & 6.1 & 7.7 & 4.2 & 1.4 & 4.6 & 0.2 & -3.8 & -1.3 \\
\hline \multirow[t]{8}{*}{ GDP deflator } & Canada & 2.1 & 3.3 & 3.2 & 3.4 & 2.5 & 3.1 & 3.8 & -1.3 & 1.3 \\
\hline & United States & 2.2 & 2.1 & 2.9 & 3.3 & 3.2 & 2.7 & 2.2 & 0.9 & 0.4 \\
\hline & Euro Area & 1.9 & 2.2 & 1.9 & 2.0 & 2.0 & 2.3 & 2.3 & 1.0 & 1.0 \\
\hline & Japan & -1.0 & -1.6 & -1.1 & -1.2 & -0.9 & -0.7 & -1.0 & 1.0 & -0.9 \\
\hline & United Kingdom & 2.4 & 3.1 & 2.5 & 2.2 & 2.6 & 2.8 & 2.3 & 2.2 & 1.9 \\
\hline & Australia & 2.9 & 3.6 & 3.4 & 4.5 & 4.4 & 4.0 & 6.7 & 2.3 & 2.9 \\
\hline & New Zealand & 2.1 & 1.6 & 3.6 & 1.9 & 2.9 & 4.0 & 2.4 & -1.7 & 0.2 \\
\hline & \multicolumn{10}{|c|}{ (In percent of GDP) } \\
\hline General government & Canada & 0.9 & -0.1 & 0.9 & 1.5 & 1.3 & 1.4 & 0.4 & -3.1 & -3.5 \\
\hline financial balance & United States & -1.7 & -4.8 & -4.4 & -3.3 & -2.2 & -2.9 & -6.1 & -13.7 & -9.8 \\
\hline & Euro Area & -2.0 & -3.0 & -2.9 & -2.5 & -1.3 & -0.7 & -1.8 & -5.4 & -6.1 \\
\hline & Japan & -6.2 & -8.0 & -6.2 & -5.0 & -4.0 & -2.5 & -5.4 & -8.7 & -8.8 \\
\hline & United Kingdom & -1.4 & -3.3 & -3.3 & -3.3 & -2.6 & -2.6 & -5.4 & -9.8 & -10.9 \\
\hline & Australia & 1.4 & 1.6 & 2.1 & 2.6 & 2.1 & 1.6 & 0.1 & -2.2 & -2.8 \\
\hline & New Zealand & 2.2 & 2.6 & 3.8 & 4.9 & 4.1 & 2.6 & 0.3 & -3.6 & -5.5 \\
\hline Gross national & Canada & 21.9 & 21.2 & 23.0 & 23.9 & 24.3 & 24.1 & 23.7 & 21.4 & 21.3 \\
\hline saving & United States & 16.0 & 13.3 & 13.8 & 14.8 & 15.5 & 14.2 & 11.9 & 11.6 & 11.3 \\
\hline & Euro Area & 21.4 & 20.7 & 21.6 & 21.2 & 22.0 & 22.4 & 21.6 & 18.8 & 18.1 \\
\hline & Japan & 27.6 & 26.1 & 26.8 & 27.2 & 27.7 & 28.9 & 26.7 & 23.5 & 23.2 \\
\hline & United Kingdom & 15.5 & 15.1 & 15.0 & 14.7 & 14.2 & 15.3 & 15.1 & 12.1 & 12.4 \\
\hline & Australia & 20.3 & 20.6 & 20.2 & 20.9 & 21.5 & 22.3 & 24.3 & 22.8 & 22.3 \\
\hline & New Zealand & 17.1 & 18.7 & 18.5 & 16.5 & 14.9 & 15.8 & 14.3 & 12.5 & 14.1 \\
\hline Fixed investment & Canada & 20.1 & 19.6 & 20.3 & 21.3 & 22.3 & 22.6 & 22.6 & 22.7 & 22.4 \\
\hline & United States & 19.3 & 18.3 & 18.9 & 19.6 & 19.7 & 18.8 & 17.8 & 15.6 & 15.0 \\
\hline & Euro Area & 20.7 & 20.1 & 20.3 & 20.7 & 21.4 & 21.9 & 21.7 & 19.8 & 19.1 \\
\hline & Japan & 24.4 & 22.8 & 22.7 & 23.3 & 23.3 & 23.4 & 23.1 & 21.6 & 21.4 \\
\hline & United Kingdom & 17.0 & 16.4 & 16.7 & 16.9 & 17.2 & 17.7 & 16.7 & 15.0 & 14.3 \\
\hline & Australia & 24.6 & 25.2 & 25.5 & 26.5 & 26.8 & 27.8 & 28.7 & 27.9 & 27.3 \\
\hline & New Zealand & 21.8 & 22.1 & 23.8 & 24.1 & 23.6 & 23.5 & 22.4 & 19.1 & 19.4 \\
\hline Current account & Canada & 1.1 & 1.2 & 2.3 & 1.9 & 1.4 & 0.9 & 0.6 & -1.7 & -1.4 \\
\hline balance & United States & -4.2 & -4.8 & -5.3 & -5.9 & -6.0 & -5.3 & -4.7 & -3.5 & -3.6 \\
\hline & Euro Area & 0.1 & 0.3 & 0.8 & 0.2 & 0.1 & 0.4 & -0.7 & -1.1 & -1.1 \\
\hline & Japan & 3.0 & 3.2 & 3.7 & 3.6 & 3.9 & 4.8 & 3.2 & 1.5 & 1.4 \\
\hline & United Kingdom & -1.9 & -1.6 & -2.1 & -2.6 & -3.4 & -2.9 & -1.7 & -2.0 & -1.5 \\
\hline & Australia & -4.5 & -5.3 & -6.1 & -5.8 & -5.3 & -6.3 & -4.2 & -4.8 & -4.9 \\
\hline & New Zealand & -5.6 & -4.3 & -6.4 & -8.5 & -8.7 & -8.2 & -8.9 & -8.1 & -6.8 \\
\hline
\end{tabular}

Sources: IMF staff estimates; and IMF, World Economic Outlook.

1/ Data generated from an interim WEO submission, as of early-April 2009. 
Table 4. Canada: Balance of Payments

(In billions of Canadian dollars, unless otherwise indicated)

\begin{tabular}{|c|c|c|c|c|c|c|c|c|c|}
\hline & \multirow[b]{2}{*}{2006} & \multirow[b]{2}{*}{2007} & \multirow[b]{2}{*}{2008} & \multicolumn{6}{|c|}{ Projections } \\
\hline & & & & 2009 & 2010 & 2011 & 2012 & 2013 & 2014 \\
\hline Current account balance & 20.2 & 13.6 & 10.2 & -25.6 & -22.4 & -12.3 & -5.2 & 2.8 & 17.1 \\
\hline In percent of GDP & 1.4 & 0.9 & 0.6 & -1.7 & -1.4 & -0.7 & -0.3 & 0.2 & 0.9 \\
\hline Merchandise trade balance & 49.5 & 48.0 & 47.2 & 5.0 & 12.9 & 23.7 & 30.5 & 38.4 & 51.7 \\
\hline Exports, goods & 453.7 & 463.1 & 489.9 & 355.0 & 385.7 & 422.5 & 459.9 & 494.2 & 525.0 \\
\hline Imports, goods & 404.3 & 415.0 & 442.7 & 350.1 & 372.8 & 398.8 & 429.4 & 455.9 & 473.3 \\
\hline Services balance & -14.8 & -19.2 & -22.5 & -22.9 & -23.2 & -23.0 & -22.1 & -20.9 & -19.6 \\
\hline Investment income balance & -13.4 & -14.2 & -14.0 & -8.4 & -12.8 & -14.2 & -15.5 & -16.9 & -17.4 \\
\hline Transfer balance & -1.1 & -1.1 & -0.4 & 0.7 & 0.7 & 1.2 & 1.9 & 2.3 & 2.4 \\
\hline Capital and financial accounts balance & -17.2 & -13.6 & -10.2 & 25.6 & 22.4 & 12.3 & 5.2 & -2.8 & -17.1 \\
\hline Direct investment, net & 26.8 & 58.9 & -31.3 & -24.7 & -18.4 & -22.5 & -7.0 & -7.8 & -9.2 \\
\hline Portfolio investment, net & -46.8 & -80.0 & 40.7 & 60.1 & 48.8 & 43.5 & 23.1 & 11.9 & -2.0 \\
\hline Other investment, net $1 /$ & -0.3 & 3.3 & -24.1 & -15.4 & -13.7 & -14.5 & -17.2 & -13.4 & -12.7 \\
\hline Capital account balance & 4.1 & 4.2 & 4.5 & 5.5 & 5.6 & 5.8 & 6.2 & 6.6 & 6.9 \\
\hline \multicolumn{10}{|l|}{ Transactions in official } \\
\hline International reserves & -1.0 & -4.6 & -1.7 & $\ldots$ & $\ldots$ & $\ldots$ & $\ldots$ & $\ldots$ & $\ldots$ \\
\hline Statistical discrepancy & -3.0 & 4.1 & -1.8 & $\cdots$ & $\cdots$ & $\cdots$ & $\cdots$ & $\cdots$ & $\cdots$ \\
\hline \multicolumn{10}{|l|}{ Memorandum item: } \\
\hline Net international investment position & -77.3 & -125.0 & 13.5 & -6.6 & -23.4 & -29.9 & -28.8 & -19.5 & 4.5 \\
\hline In percent of GDP & -5.3 & -8.1 & 0.8 & -0.4 & -1.5 & -1.8 & -1.7 & -1.1 & 0.2 \\
\hline
\end{tabular}

Sources: Haver Analytics; and Fund staff calculations.

1 / Includes bank, nonbank, and official transactions other than reserve transactions. 
Table 5. Canada: Selected Vulnerability Indicators

(In percent of GDP, unless otherwise indicated)

\begin{tabular}{|c|c|c|c|c|c|c|c|}
\hline & 2002 & 2003 & 2004 & 2005 & 2006 & 2007 & 2008 \\
\hline \multicolumn{8}{|l|}{ External indicators } \\
\hline $\begin{array}{l}\text { Official reserves (in billions of U.S. dollars) } \\
\text { Broad money (M3) to foreign }\end{array}$ & 37.2 & 36.3 & 34.5 & 33.0 & 35.1 & 41.1 & 43.9 \\
\hline exchange reserves (ratio) & 12.7 & 16.8 & 20.8 & 24.6 & 24.8 & 27.6 & 23.5 \\
\hline Official reserves in months of imports & 1.6 & 1.4 & 1.1 & 1.0 & 1.0 & 1.0 & 1.2 \\
\hline $\begin{array}{l}\text { General government external debt } \\
\text { (in billions of dollars) } 1 /\end{array}$ & 78.9 & 60.9 & 54.7 & 49.1 & 52.1 & 45.8 & 49.5 \\
\hline $\begin{array}{l}\text { Net international investment position, } \\
\text { current prices }\end{array}$ & -18.1 & -17.9 & -14.8 & -11.6 & -5.3 & -8.1 & 0.8 \\
\hline in percent of exports & 43.7 & 47.0 & 38.5 & 30.8 & 14.8 & 23.6 & -2.4 \\
\hline $\begin{array}{l}\text { External interest payments to exports } \\
\quad \text { (in percent) } 2 /\end{array}$ & 12.7 & 12.9 & 12.6 & 13.7 & 14.9 & 16.1 & 14.9 \\
\hline \multicolumn{8}{|l|}{ Financial markets indicators } \\
\hline General government gross debt & 80.6 & 76.6 & 72.4 & 70.5 & 67.9 & 64.2 & 63.6 \\
\hline Three-month treasury bill yield (percent) & 2.6 & 2.9 & 2.2 & 2.7 & 4.0 & 4.2 & 2.4 \\
\hline Ten-year government note (percent) & 5.3 & 4.8 & 4.6 & 4.1 & 4.2 & 4.3 & 3.6 \\
\hline $\begin{array}{l}\text { Real three-month treasury bill yield } \\
\text { (percent; deflated by CPI rate) }\end{array}$ & 0.3 & 0.1 & 0.4 & 0.5 & 2.0 & 2.0 & 0.0 \\
\hline Change in stock market index & & & & & & & \\
\hline (TSE 300, annual percentage change) & -14.0 & 24.3 & 12.5 & 21.9 & 14.5 & 7.2 & -35.0 \\
\hline \multicolumn{8}{|l|}{$\begin{array}{l}\text { Banking sector risk indicators } 3 / \\
\text { Balance sheet }\end{array}$} \\
\hline Total loans to assets (percent) & 55.9 & 54.1 & 54.3 & 55.1 & 53.7 & 53.1 & 51.3 \\
\hline Total loans to deposits (percent) & 83.3 & 81.4 & 81.7 & 81.0 & 81.5 & 81.1 & 79.7 \\
\hline Impaired assets/total assets & 0.90 & 0.65 & 0.39 & 0.27 & 0.22 & 0.23 & 0.30 \\
\hline Loan loss provision (in percent of total assets) & 0.57 & 0.23 & 0.06 & 0.09 & 0.09 & 0.12 & 0.21 \\
\hline Total foreign currency assets/total assets $4 /$ & 41.4 & 36.2 & 34.1 & 34.7 & 38.8 & 36.3 & 42.2 \\
\hline Total foreign currency liabilities/total assets 4/ & 43.8 & 37.7 & 35.1 & 36.1 & 39.8 & 37.8 & 42.0 \\
\hline Total foreign currency deposits/total assets 4/ & 28.9 & 25.6 & 23.2 & 25.1 & 26.8 & 25.9 & 26.9 \\
\hline \multicolumn{8}{|l|}{ Profitability } \\
\hline Return on total shareholders' equity (in percent) & 9.3 & 14.7 & 16.7 & 14.6 & 21.7 & 19.6 & 10.8 \\
\hline Return on average assets (in percent) & 0.44 & 0.69 & 0.79 & 0.67 & 0.96 & 0.88 & 0.50 \\
\hline Average intermediation spread & 3.0 & 3.1 & 3.0 & 2.7 & 2.7 & 2.4 & 2.4 \\
\hline Net interest income & & & & & & & \\
\hline (in percent of average total assets) & 2.1 & 2.0 & 1.8 & 1.8 & 1.7 & 1.6 & 1.7 \\
\hline \multicolumn{8}{|l|}{ Capital position } \\
\hline Total capital ratio & 12.4 & 13.4 & 13.3 & 12.9 & 12.5 & 12.1 & 12.7 \\
\hline Tier 1 capital ratio & 9.2 & 10.3 & 10.6 & 10.2 & 10.5 & 9.8 & 9.9 \\
\hline \multicolumn{8}{|l|}{ Personal sector $5 /$} \\
\hline Net worth (in percent of disposable income) & 512.7 & 516.1 & 518.1 & 534.6 & 546.7 & 549.2 & 543.9 \\
\hline Total liabilities (in percent of disposable income) & 117.1 & 120.6 & 124.3 & 129.7 & 133.0 & 138.7 & 142.4 \\
\hline Total liabilities (in percent of net worth) & 22.8 & 23.4 & 24.0 & 24.3 & 24.3 & 25.3 & 26.2 \\
\hline Household credit (growth rate, percent) & 7.1 & 8.5 & 10.3 & 11.1 & 10.6 & 11.0 & 11.0 \\
\hline \multicolumn{8}{|l|}{ Corporate sector $6 /$} \\
\hline $\begin{array}{l}\text { Debt of private nonfinancial corporations } \\
\text { Debt-to-equity ratio of }\end{array}$ & 51.2 & 46.3 & 45.1 & 44.2 & 45.1 & 44.9 & 47.7 \\
\hline nonfinancial private corporations & 68.5 & 59.3 & 56.6 & 54.5 & 54.4 & 53.3 & 55.5 \\
\hline Business credit (growth rate, percent) & 4.4 & 1.7 & 4.3 & 5.9 & 6.0 & 6.8 & 5.8 \\
\hline
\end{tabular}

Sources: Bloomberg; Canadian Bankers' Association; Haver Analytics; and Office of the Superintendent of Financial Institutions.

1/ Defined as Government of Canada securities held by nonresidents.

2/ Income payments on foreign-owned assets (other private payments plus Canada government payments).

3/ Unless otherwise indicated, based on data for the six largest chartered Canadian banks, which account for over 90 percent of the total market.

4/ All chartered banks.

5/ Persons and unincorporated business.

6/ Based on total debt less trade payables, corporate claims, and other liabilities. 
Table 6. Canada: Fiscal Indicators

\begin{tabular}{|c|c|c|c|c|c|c|c|c|c|c|c|c|}
\hline & \multirow[b]{2}{*}{$2003 / 04$} & \multirow[b]{2}{*}{$2004 / 05$} & \multirow[b]{2}{*}{$2005 / 06$} & \multirow[b]{2}{*}{$2006 / 07$} & \multirow[b]{2}{*}{$2007 / 08$} & \multicolumn{7}{|c|}{ Staff Projections } \\
\hline & & & & & & $2008 / 09$ & $2009 / 10$ & $2010 / 11$ & $2011 / 12$ & $2012 / 13$ & $2013 / 14$ & $2014 / 15$ \\
\hline & \multicolumn{12}{|c|}{ (In billions of dollars) } \\
\hline \multicolumn{13}{|l|}{ Federal government (PA basis) $1 /$} \\
\hline Revenue & 198.6 & 211.9 & 222.2 & 236.0 & 242.4 & 234.3 & 220.0 & 229.3 & 243.9 & 261.3 & 281.1 & 304.8 \\
\hline Program spending & 153.7 & 176.4 & 175.2 & 188.3 & 199.5 & 207.4 & 231.2 & 238.9 & 236.3 & 244.7 & 253.6 & 262.6 \\
\hline Interest payments & 35.8 & 34.1 & 33.8 & 33.9 & 33.3 & 31.0 & 28.6 & 28.6 & 28.6 & 30.8 & 33.8 & 39.0 \\
\hline Budgetary balance & 9.1 & 1.5 & 13.2 & 13.8 & 9.6 & -4.1 & -39.8 & -38.2 & -21.0 & -14.2 & -6.3 & 3.1 \\
\hline Structural budgetary balance & 11.0 & 1.7 & 11.7 & 10.1 & 6.3 & 1.2 & -25.0 & -22.6 & -8.3 & -7.1 & -3.2 & 4.5 \\
\hline Gross federal debt $3 /$ & 700.1 & 705.0 & 702.5 & 705.8 & 692.3 & 766.4 & 863.9 & 902.1 & 923.1 & 937.3 & 943.6 & 940.5 \\
\hline \multirow[t]{2}{*}{ Net federal debt $3 /$} & 496.2 & 494.7 & 481.5 & 467.3 & 457.6 & 461.7 & 501.5 & 539.7 & 560.7 & 574.9 & 581.2 & 578.1 \\
\hline & \multicolumn{12}{|c|}{ (In percent of GDP) } \\
\hline Revenue & 16.4 & 16.4 & 16.2 & 16.3 & 15.8 & 14.6 & 14.3 & 14.5 & 14.9 & 15.0 & 15.3 & 15.8 \\
\hline Program spending & 12.7 & 13.7 & 12.8 & 13.0 & 13.0 & 12.9 & 15.0 & 15.1 & 14.4 & 14.1 & 13.8 & 13.6 \\
\hline Interest payments & 2.9 & 2.6 & 2.5 & 2.3 & 2.2 & 1.9 & 1.9 & 1.8 & 1.7 & 1.8 & 1.8 & 2.0 \\
\hline Budgetary balance & 0.8 & 0.1 & 1.0 & 0.9 & 0.6 & -0.3 & -2.6 & -2.4 & -1.3 & -0.8 & -0.3 & 0.2 \\
\hline Structural budgetary balance $2 /$ & 0.9 & 0.1 & 0.8 & 0.7 & 0.4 & 0.1 & -1.5 & -1.4 & -0.5 & -0.4 & -0.2 & 0.2 \\
\hline Gross federal debt $3 /$ & 57.7 & 54.6 & 51.2 & 48.7 & 45.1 & 47.8 & 56.1 & 57.1 & 56.2 & 53.8 & 51.3 & 48.8 \\
\hline \multirow[t]{2}{*}{ Net federal debt $3 /$} & 40.9 & 38.3 & 35.1 & 32.2 & 29.8 & 28.8 & 32.6 & 34.2 & 34.1 & 33.0 & 31.6 & 30.0 \\
\hline & \multicolumn{12}{|c|}{ (In billions of dollars) } \\
\hline \multicolumn{13}{|l|}{ General government 4/ } \\
\hline Revenue & 494.7 & 522.7 & 557.1 & 586.3 & 618.0 & 633.2 & 603.4 & 619.7 & 649.5 & 697.6 & 746.8 & 797.6 \\
\hline Expenditure & 495.7 & 511.5 & 535.9 & 566.9 & 596.7 & 626.8 & 651.1 & 674.5 & 689.0 & 721.1 & 754.8 & 790.2 \\
\hline Balance & -1.0 & 11.1 & 21.2 & 19.4 & 21.3 & 6.4 & -47.7 & -54.8 & -39.5 & -23.5 & -7.9 & 7.4 \\
\hline Gross public debt & 1127.7 & 1139.9 & 1184.2 & 1197.8 & 1199.3 & 1311.4 & 1448.1 & 1502.9 & 1542.4 & 1565.9 & 1573.9 & 1566.4 \\
\hline \multirow[t]{2}{*}{ Net public debt } & 667.5 & 656.7 & 628.4 & 595.5 & 574.2 & 562.9 & 610.5 & 665.3 & 704.8 & 728.3 & 736.3 & 728.9 \\
\hline & \multicolumn{12}{|c|}{ (In percent of GDP) } \\
\hline Revenue & 40.8 & 40.5 & 40.6 & 40.4 & 40.2 & 39.5 & 39.2 & 39.2 & 39.5 & 40.1 & 40.6 & 41.4 \\
\hline Expenditure & 40.9 & 39.6 & 39.0 & 39.1 & 38.9 & 39.1 & 42.3 & 42.7 & 42.0 & 41.4 & 41.0 & 41.0 \\
\hline Balance & -0.1 & 0.9 & 1.5 & 1.3 & 1.4 & 0.4 & -3.1 & -3.5 & -2.4 & -1.3 & -0.4 & 0.4 \\
\hline Gross public debt & 93.0 & 88.3 & 86.3 & 82.6 & 78.1 & 81.8 & 94.0 & 95.2 & 93.9 & 90.0 & 85.6 & 81.3 \\
\hline Net public debt & 55.0 & 50.9 & 45.8 & 41.1 & 37.4 & 35.1 & 39.6 & 42.1 & 42.9 & 41.8 & 40.0 & 37.8 \\
\hline \multicolumn{13}{|l|}{ Memorandum items } \\
\hline Real GDP growth & 1.9 & 3.1 & 2.9 & 3.1 & 2.7 & 0.5 & -2.6 & 1.2 & 2.5 & 3.9 & 3.4 & 2.5 \\
\hline Nominal GDP growth rate & 5.2 & 6.4 & 6.3 & 5.7 & 5.9 & 4.4 & -3.9 & 2.5 & 4.0 & 6.0 & 5.7 & 4.8 \\
\hline Three-month treasury bill rate & 2.9 & 2.2 & 2.7 & 4.0 & 4.2 & 2.4 & 0.5 & 0.6 & 2.6 & 4.3 & 4.8 & 4.8 \\
\hline Ten-year government bond rate & 4.8 & 4.6 & 4.1 & 4.2 & 4.3 & 3.6 & 2.7 & 2.8 & 4.2 & 5.2 & 5.5 & 5.5 \\
\hline
\end{tabular}

Sources: Department of Finance Canada The 2009 Budget; Haver Analytics; and Fund staff estimates.

$1 /$ On a fiscal year basis, which starts on April 1.

2/ In percent of potential GDP.

$3 /$ Assuming all deficit/surplus is added/subtracted from debt.

4/ On a national accounts and calendar year basis. Includes federal, provincial, territorial, and local governments; and Canada and Quebec pension plans. 


\section{INTERNATIONAL MONETARY FUND CANADA \\ Staff Report for the 2009 Article IV Consultation-Informational Annex \\ Prepared by Western Hemisphere Department \\ (In consultation with other departments)}

April 17, 2009

Contents

Page

I. Fund Policy Advice ...........................................................................................

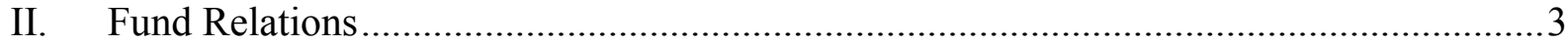

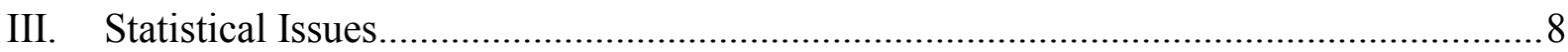




\section{Annex I. Canada-Fund Policy Advice Not Discussed in the Staff Report}

The Bank of Canada is contemplating shifting its target away benefits include reducing uncertainty about future price levels tends to hurt agents who receive income fixed in nominal terms or who are risk averse and enter into long-term, nominal contracts (e.g. home mortgages).

High marginal effective rates (METRs) on capital, saving, and labor income.

The agreement to lock in federal health transfers over the next 10 years provides provinces with opportunities to improve the efficiency and quality of health care. from annual inflation (IT) to a price level path (PLPT). The and avoiding the price level drift that occurs under IT, which
Canada's current IT framework has been very successful, at the same time Canada may already be reaping some of the benefits of price level targeting in terms of anchoring expectations about the future price level. Thus benefits of a formal shift to PLPT should be weighed against the costs of abandoning an effective and credible IT framework.

\section{Fiscal Policy}

Harmonizing remaining provincial sales taxes with the GST base, including by providing explicit incentives to provinces to move towards that direction; protecting all types of saving from taxes up to a cap, and supporting wealth creation by moving taxes up to a cap, and supporting wealth creation by moving lowering METR on labor income.

Allowing provinces greater flexibility in using price and other market-based mechanisms could help align the demand and supply for health care and reduce costs over time.
Since the introduction of IT, a unique combination of shocks has aligned Canada's inflation (on average at the 2-percent target) to the outcome of a PLPT regime. This minimizes credibility risks from a regime switch, but BoC is still studying the possible gains of such move and it does not plan changes to the IT regime before the 2011 review.

Willing to work with the remaining provinces on harmonization-Ontario has signed a Memorandum of Agreement with the federal government to join the Harmonized Sales Tax Framework in July 2010; creation of the Tax Savings Account for up to C $\$ 5,000$, effective in 2009; provided significant personal tax relief since 2006, including increasing the basic personal amount,
income level at which the National Child Benefit income level at which the National Child Benefit
supplement for low-income families is fully phased out and supplement for low-income families is fully phased out and the income level at which the base benefit of th
Child Tax Benefit begins to be phased out.

The Canada Health Act allows for private service delivery, and provinces are actively exploring different approaches to improve competition. Even low user fees could reduce access to health care by the poor.

\section{Financial Policy}

The distribution of $A B C P$ is exempt from securities regulators registration and prospectus requirements, which may have contributed to the damage caused by the seizure of the thirdparty $A B C P$ market

Canada maintains an Employment Insurance System that offers generous seasonal, regional, and family leave benefits, funded by payroll tax.

Canada can play an important role in the Doha negotiations.

Barriers to interprovincial trade and labor mobility hamper competition and innovation, while stringent FDI review process might hinder international investment.
The short-term debt loophole that was exploited by non-bank $A B C P$ issuers should be closed.
Provincial regulators have proposed amending the shortterm debt exemption so that it is unavailable to $A B C P$.

\section{Labor Markets}

Consideration could be given to funding social benefits of the Employment Insurance System through general revenues and to curbing extended regional benefits.

\section{Trade Policy}

Canada needs to widen market access for agricultural goods, including those subject to "supply management" schemes

Freeing mobility in goods, services and regulated professions between all provinces along the lines of the Trade, Investment and Labor Mobility Agreement (TILMA) between Alberta and British Columbia. Remove stringent rules in FDI flows.
Recent reforms to the Employment Insurance System have improved its funding. No significant changes in benefits are currently being considered, apart from the temporary extension by 5 weeks given the downturn.

Canada remains committed to a successful completion of the Doha round; though it will continue to support supply management schemes. Canada has also been pursuing bilateral free trade agreements, more recently with Colombia and Peru.

In January 2009, the First Ministers agreed on a full labor mobility by April 2009, and the federal government has streamlined immigration procedures. The Ministers also agreed to identify priority areas for progress on harmonizing business regulations and standards. Revisions to the Investment Act along the recommendations of the Competition Policy Review Panel are under way. 


\section{Annex II. Canada-Fund Relations}

(As of March 31, 2009)

I. Membership Status: Joined 12/27/45; Article VIII

II. General Resources Account:

Quota

Fund holdings of currency

Reserve position in Fund

III. SDR Department:

Net cumulative allocation

Holdings
SDR
Million

$6,369.20$

$5,332.73$

$1,036.47$

SDR

Million

779.29

644.48
Percent

of Quota

100.00

83.73

16.27

Percent of

Allocation

100.00

82.70

IV. Outstanding Purchases and Loans: None

V. Financial Arrangements: None.

VI. Projected Obligations to Fund:

(SDR Million; based on existing use of resources and present holdings of SDRs):

$\begin{array}{llllll}\text { Principal } & \mathrm{n} / \mathrm{a} & \mathrm{n} / \mathrm{a} & \mathrm{n} / \mathrm{a} & \mathrm{n} / \mathrm{a} & \mathrm{n} / \mathrm{a} \\ \text { Charges/Interest } & 0.50 & 0.62 & 0.62 & 0.62 & 0.62 \\ \text { Total } & 0.50 & 0.62 & 0.62 & 0.62 & 0.62\end{array}$

VII. Implementation of HIPC Initiative: Not applicable.

VIII. Safeguards Assessments: Not applicable.

IX. Exchange Rate Arrangements: The Canadian authorities do not maintain margins with respect to exchange transactions. The Canadian dollar is a freely floating currency, with exchange rates determined on the basis of demand and supply conditions in the foreign exchange market. However, the authorities may intervene to maintain orderly conditions in the exchange market. There are no taxes or subsidies on purchases or sales of foreign exchange. Canada has accepted the obligations of Article VIII, Sections 2, 3, and 4(a) and maintains an exchange system that is free of restrictions on the making of payments and transfers for current international transactions. Canada maintains exchange restrictions for security reasons, based on UN Security Council Resolutions, that have been notified to the Fund for approval (most recently in December 2007) under the procedures set forth in Executive Board Decision No. 144-(52/51). 
X. Last Article IV Consultation: The Staff Report for the 2008 consultation with Canada was considered by the Executive Board on February 6, 2008 (IMF Country Report No. 08/69, 2/25/08). Canada is on a 12-month consultation cycle.

XI. The 2009 Article IV discussions were conducted in Ottawa and Toronto from February 23-March 3 by C. Kramer (head), M. Estevão, R. Duttagupta, E. Tsounta, L. Ratnovski (all WHD), and J. Kiff (MCM). An advance mission team visited Alberta in December 2008. Mr. St-Amant (Senior Advisor) attended the meetings. Mr. Eyzaguirre (WHD) and Mr. Horgan (Executive Director) participated in the concluding meeting with Minister of Finance Flaherty and Bank of Canada Senior Deputy Governor Jenkins in Ottawa on March 9. A press conference was held on March 11. Outreach included discussions with the private sector, labor unions, academics, and think tanks.

\section{FSSA Participation and ROSC Assessments}

\section{Canada-Financial System Stability Assessment-} Volume II: Report on Observance of Standards in the Financial System

(www.imf.org)

Summary: The FSSA report concluded that Canada has a stable and highly advanced financial system, which is among the soundest in the world. Moreover, it is supported by a well-developed regulatory system that shows a high degree of compliance with major international standards. Nevertheless, the FSSA report made a few recommendations to further strengthen the regulatory framework and financial system's resilience, most of which have already been addressed, including:

- Introducing capital requirements for the guarantees in life insurance segregated fund (completed by end-2001);

- $\quad$ Tabling legislation granting the Office of the Superintendent of Financial Institutions (OSFI) powers to remove a financial institution's director or senior officer if the person is deemed not suitable to hold that office based on a number of criteria. The latter legislation brought Canada into broad compliance with the Basel Core Principles;

Making significant progress in harmonizing securities regulation and improving coordination among provincial securities regulators, including through a newly created association of securities regulators, the Canadian Securities Administrators. Although there remain multiple regulators at the provincial level, a Senate commission was created to develop specific recommendations on further harmonization and streamlining of securities regulation. 
Canada: Report on the Observance of Standards and Codes-Fiscal Transparency Module

IMF Country Report

No. 02/51, 03/12/02

Summary: The report found that fiscal management in Canada meets the requirements of the fiscal transparency code, and in a number of instances represents best practice. In particular, it highlighted the use of private sector economic forecasts. Fiscal management was also commended for its statistical integrity, impartial tax administration, open procurement, and a transparent regulatory process.

The report found several areas where further improvements would be desirable, including: (i) the preparation of timely, current year estimates of federal and provincial budgets on a comparable basis, (ii) a comprehensive account of the procedures for the budget cycle and expenditure management system, (iii) systematic reporting of the use of reserves for non-economic contingencies, (iv) resumption of publication of reconciled national and public accounts forecasts of major aggregates over the forecast horizon, and (v) publication by all governments of quasi-fiscal activities.

Many of these issues have been addressed, including: (i) the release by Statistics Canada of consolidated data for federal and provincial budgets for 2001-02 (on a Financial Management System basis); (ii) the publication of comprehensive descriptions of budget and expenditure management procedures, including a joint document entitled "Budgeting in Canada" by the Government and the OECD, detailed accounts of policies and procedures on expenditure management at the website of the Treasury Board Secretariat, and the explanation of the budget cycle and process in Budget and Update documents; and (iii) publication of reconciled national and public accounts forecasting.

\section{Canada: Report on the Observance of Standards IMF Country Report and Codes-Data Module No. 03/328, 10/23/03}

Summary: Canada's macroeconomic statistics are comprehensive, timely, and accurate and thus adequate to conduct effective surveillance of economic and financial policies. Official institutions responsible for the compilation and dissemination of the macroeconomic datasets are supported by adequate legal and institutional frameworks. These frameworks protect confidentiality and ensure that statistical work is conducted within a quality assurance program and with sufficient resources. Integrity is ensured by the professionalism of the staff, transparency in statistical policies and practices, and the provision of ethical guidelines for staff. Compilers generally follow internationally accepted guidelines in the production of the macroeconomic statistics, which is well-supported by excellent efforts to develop source data that facilitate a high degree of accuracy and reliability. Statistics are generally relevant, well documented, available with good frequency on a timely basis, and readily accessible to users, who trust them as objective. 
While recognizing the high quality of the macroeconomic data, the report makes recommendations to further strengthen the statistical system, most of which are already being addressed, including these priorities:

- Articulate the roles of Statistics Canada and the Bank of Canada in producing financial sector statistics and explore possibilities for more data sharing of monetary and financial statistics;

- Estimate consumption of fixed capital at replacement cost rather than historic costs now used for the corporate sector in the Canadian System of National Accounts (CSNA);

- Disseminate information on the sources and methods used in compiling quarterly public sector statistics for the quarterly CSNA; and

- Reclassify certain transactions that are not recorded in line with the $5^{\text {th }}$ edition of the Balance of Payments Manual (BPM5).

Canada: Report on the Observance of Standards and Codes-FATF Recommendations for AntiMoney Laundering and Combating the

Financing of Terrorism

Summary: Canada underwent a detailed FATF evaluation of its anti-money laundering and combating the financing of terrorism (AML/CFT) framework in 2007. Shortcomings were identified with respect to the scope of customer due diligence, AML/CFT supervision, and the Canadian financial intelligence unit. Since then, a number of steps have been taken to strengthen the framework in these three areas, resulting in significant improvements.

Canada: Financial System Stability Assessment- $\quad$ IMF Country Report Update No. 08/59, 02/13/08

Summary: The FSSA update concluded that Canada's financial system is mature, sophisticated, and well-managed. Financial stability was underpinned by sound macroeconomic policies and strong prudential regulation and supervision, and welldesigned deposit insurance and arrangements for crisis management and failure resolution. The banking system appeared sound, with stress tests showing that the major banks could withstand sizeable shocks, although they did faces some challenges related to the global financial turmoil that started in mid-2007. Also, there were some concerns about bank attempts to build on their secure domestic position, to enter highly competitive foreign markets or complex activities.

The update reiterated the advantages of moving towards a single securities regulator, including the streamlining of policy development, reductions in compliance costs, and improved enforcement. However, it also recognized the significant improvements to 
the regulatory system from the creation of the Canadian Securities Administrators (CSA), and the implementation of the passport system.

XIII. Technical Assistance: Not applicable.

XIV. Resident Representative: Not applicable 


\section{Annex III. Statistical Issues}

The quality, coverage, periodicity, and timeliness of Canada's economic data are considered to be excellent both in the context of the Article IV consultation and for purposes of ongoing surveillance. Canada has subscribed to the Fund's Special Data Dissemination Standard (SDDS), and its metadata are posted on the Fund's Dissemination Standards Bulletin Board (DSBB).

Real Sector. Statistics Canada provides timely and adequate data in monthly, quarterly, and annual frequency thereby facilitating the analysis of economic developments and assessment of policy proposals within a quantitative macroeconomic framework. In May 2001, Statistics Canada effected a smooth transition from Laspeyres methodology for estimating real expenditure-based GDP to Fisher index formulae, which enabled more accurate comparison between Canada and other G-7 countries.

Fiscal Sector. The Department of Finance Canada provides monthly and annual data on the federal government's budget, tax policies, rules and regulations for Canada's banks and other financial institutions. The provided data enable adequate assessment of the impact of fiscal policy measures on Canada's economic performance.

Monetary Sector. The Bank of Canada provides timely and adequate coverage of daily, weekly, monthly and quarterly data related to the monetary sector.

External Sector. Statistics Canada provides timely information on a quarterly frequency on the balance of payments, external debt, and the international investment position (IIP). Finance Canada provides monthly data on Official International Reserves in a format comparable to the IMF's reserve data template, thus enabling adequate surveillance. Data are published at http://www.fin.gc.ca/finsearch/finresults_e.asp?Who=News. 


\section{CANADA: TABLE OF COMMON INDICATORS REQUIRED FOR SURVEILLANCE}

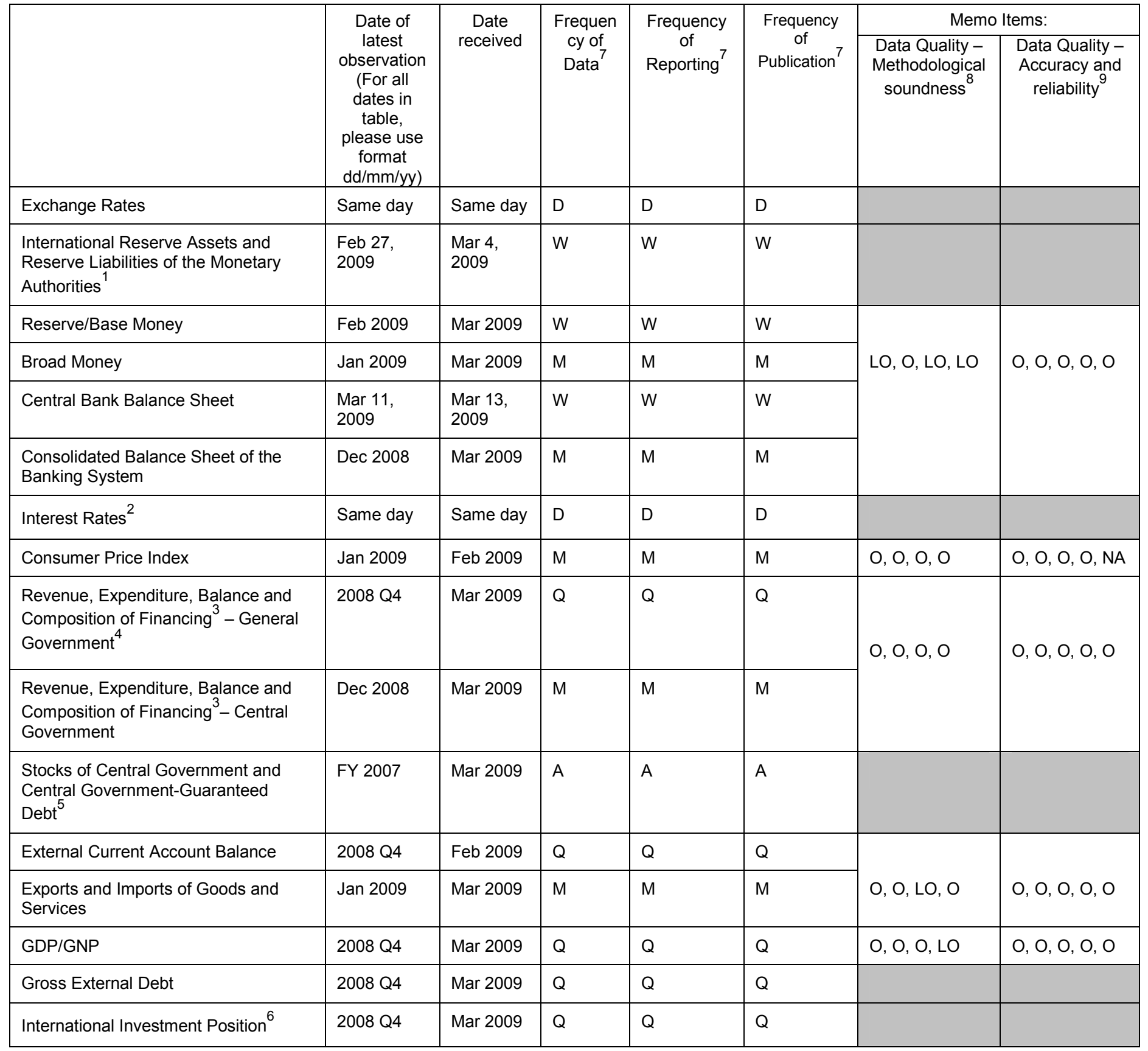

${ }^{1}$ Any reserve assets that are pledged or otherwise encumbered should be specified separately. Also, data should comprise short-term liabilities linked to a foreign currency but settled by other means as well as the notional values of financial derivatives to pay and to receive foreign currency, including those linked to a foreign currency but settled by other means.

${ }^{2}$ Both market-based and officially-determined, including discount rates, money market rates, rates on treasury bills, notes and bonds.

${ }^{3}$ Foreign, domestic bank, and domestic nonbank financing.

${ }^{4}$ The general government consists of the central government (budgetary funds, extra budgetary funds, and social security funds) and state and local governments.

${ }^{5}$ Including currency and maturity composition.

${ }^{6}$ Includes external gross financial asset and liability positions vis-à-vis nonresidents.

${ }^{7}$ Daily (D); weekly (W); monthly (M); quarterly (Q); annually (A); irregular (I); and not available (NA).

${ }^{8}$ Reflects the assessment provided in the data ROSC published on October 23, 2003 and based on the findings of the mission that took place during January 22February 5, 2003 for the dataset corresponding to the variable in each row. The assessment indicates whether international standards concerning (respectively) concepts and definitions, scope, classification/sectorization, and basis for recording are fully observed (O), largely observed (LO), largely not observed (LNO), not observed (NO); and not available (NA).

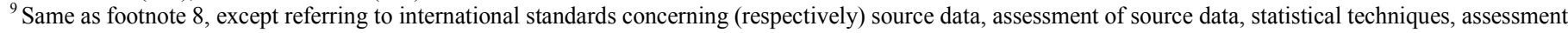
and validation of intermediate data and statistical outputs, and revision studies. 


\section{INTERNATIONAL MONETARY FUND}

EXTERNAL

Public Information Notice

RELATIONS

DEPARTMENT

Public Information Notice (PIN) No. 09/66

FOR IMMEDIATE RELEASE

May 22, 2009

International Monetary Fund

$70019^{\text {th }}$ Street, NW

Washington, D. C. 20431 USA

\section{IMF Executive Board Concludes 2009 Article IV Consultation with Canada}

On May 11, 2009, the Executive Board of the International Monetary Fund (IMF) concluded the Article IV consultation with Canada. ${ }^{1}$

\section{Background}

Canada entered the crisis on a solid footing, reflecting a strong macroeconomic framework, rigorous financial regulation, and robust corporate balance sheets. Through 2007, sound macroeconomic and financial policies along with a commodity boom delivered strong growth, stable inflation, fiscal and current account surpluses, historically low unemployment and financial stability. But nevertheless, the crisis has significantly affected Canada's economic and financial conditions, given its openness to trade and financial flows.

Real GDP contracted by 3.4 percent (seasonally adjusted annual rate) in the fourth quarter of 2008 after a weak performance earlier in the year, driven by a 5-percent decline in domestic demand as the terms of trade, credit conditions, equity prices, and employment deteriorated abruptly. Net external trade contributed positively to growth, as imports plummeted more than exports. The economy contracted further in early 2009 , reflecting the sharp downturn in the United States and further tightening of financial conditions, but is expected to rebound moderately later in the year boosted by fiscal and monetary stimulus. GDP is projected to fall 21/2 percent year-over-year in 2009 before recovering somewhat at a 1.2-percent rate in 2010 . Unemployment is expected to reach a 10-year high of around 91/4 percent in mid-2010, while

\footnotetext{
${ }^{1}$ Under Article IV of the IMF's Articles of Agreement, the IMF holds bilateral discussions with members, usually every year. A staff team visits the country, collects economic and financial information, and discusses with officials the country's economic developments and policies. On return to headquarters, the staff prepares a report, which forms the basis for discussion by the Executive Board. At the conclusion of the discussion, the Managing Director, as Chairman of the Board, summarizes the views of Executive Directors, and this summary is transmitted to the country's authorities.
} 
the increasing output gap should dampen price pressures, with headline inflation averaging about zero in 2009.

In late 2008, Canada's current account position turned negative, for the first time in a decade, as the terms of trade fell by over 30 percent (seasonally adjusted annual rate) and real exports plummeted by about 20 percent (saar). The latter largely reflected both a sharp deterioration in manufacturing trade in response to the U.S. downturn and the impact of past currency appreciation. The Canadian dollar has served as an effective shock absorber, following trends in commodity prices: a 35-percent appreciation in real effective terms during boom years (2002 to 2007) and a 12-percent depreciation in the fourth quarter of 2008.

The Bank of Canada (BoC) has cut policy rates by 425 basis points since December 2007 to $1 / 4$ percent-a historic low and an effective lower bound - and expanded liquidity through enhanced facilities. The BoC has committed to keep the policy interest rate at its current level through the end of the second quarter in 2010 (conditional on the inflation outlook), and increased the length of its repo facilities. It has also announced a framework for quantitative and credit easing, to be deployed if downside risks to growth materialize. The need for these unconventional measures would be assessed at each monetary policy meeting, with due attention to risks to the Bank's balance sheet and the exit strategy.

Building on the permanent tax relief measures announced in October 2007, the authorities tabled further fiscal stimulus of around 2.8 percent of GDP in January 2009. Taking into account supplementary provincial actions announced following the federal budget, the measures are among the largest across G-20 countries. The stimulus relies mainly on infrastructure spending, support to the vulnerable sectors, enhanced social safety nets and retraining programs for job reallocation, and tax reductions and incentives. Its deployment is being monitored via quarterly parliamentary reviews. The package and the economic downturn will end an 11-year string of fiscal surpluses, which allowed Canada to achieve the lowest debt-to-GDP ratio among G-7 countries.

The financial system has avoided systemic pressures amid the global turbulence, thanks in good part to strong supervision and regulation. No institution has failed or required public capital injection, and banks have raised capital in markets (albeit at an elevated cost). Despite this resilience, the crisis has widened interbank spreads, credit conditions have tightened, and borrowing costs have risen significantly. Meanwhile, the plunge in equity markets has put strains on life insurers, pension funds and mutual funds. However, since the beginning of the year financial conditions have generally improved in Canada.

The authorities have taken proactive steps to safeguard financial stability. They have launched facilities to offer guarantees on wholesale borrowing for banks and insurance companies, and purchased mortgage-backed securities to ease liquidity pressures, and announced additional support to certain credit markets. In addition, the authorities have obtained the mandate for public capital injections and for the creation of a bridge bank by the Canadian Deposit Insurance Corporation, if needed. 


\section{Executive Board Assessment}

Executive Directors commended Canada's impressive macroeconomic track record, strong policy framework and proactive response to the crisis. These factors place Canada in a better position than most countries to weather the global financial crisis, and the financial strains evident elsewhere are markedly less serious in Canada. Directors observed, however, that the near-term economic outlook will be challenging in light of the sharp deterioration in the global environment and Canada's strong international linkages. They saw risks, including from macro-financial linkages, as tilted to the downside, and called for continued vigilance and readiness to act, if tail risks materialize.

Against this background, Directors welcomed the Bank of Canada's aggressive monetary easing, expanded facilities, and the recently announced framework for the conduct of monetary policy at low interest rates. They concurred that maintaining a highly accommodative stance in the foreseeable future would limit downside risks to economic growth and inflation, while continuing to support financial stability. Directors saw continued clear communication to bolster the commitment to a sustained accommodative stance as appropriate. In a downside risk scenario, the Bank of Canada could pursue further unconventional measures, with due attention to the exit strategy and the soundness of the Bank's balance sheet.

Directors agreed that the policy of a freely-floating exchange rate has continued to serve Canada well, given the country's openness to international trade and financial flows. In particular, the flexible exchange rate has served as an effective "shock absorber" in the context of sizable commodities shocks. They noted the staff's assessment that the value of the Canadian dollar is broadly in line with economic fundamentals, having weakened with the decline in commodity prices.

Executive Directors commended the authorities' bold fiscal stimulus package, utilizing the space provided by past strong fiscal performance, and agreed that the near-term focus should be on implementation. They saw the federal stimulus package as timely, appropriately sized, diversified, and well structured, with steps to facilitate labor reallocation and protect the vulnerable. The quarterly monitoring framework will be useful to assess implementation and effectiveness of budget outlays. Directors also commended Canada for further liberalizing its trade regime by lowering tariffs.

Directors agreed that Canada would be well-positioned to participate in a further, internationally coordinated stimulus effort, if warranted. Given Canada's strong fiscal position - with the lowest debt-to-GDP ratio among G-7 countries—and the authorities' commitment to medium-term structural surpluses, further fiscal expansion would not put at risk debt sustainability. It would be important to ensure that any further measures are quickly applicable and self-reversing. Meanwhile, Directors considered it appropriate to allow automatic stabilizers to operate.

Looking beyond the crisis, Directors welcomed the authorities' objective to maintain Canada's fiscal credibility. They saw scope to recalibrate the debt targets, once the outlook clarifies, to underpin that objective. Future debt reduction would also provide fiscal space needed for future costs related to population aging and health care. 
Directors noted the resilience of Canada's banks relative to their international peers, observing that no Canadian bank has required public capital injections or guarantees. Rigorous limits on leverage, robust regulatory capital ratios, effective supervision, and smooth cooperation across regulatory agencies have underpinned financial stability. Directors commended the authorities for the proactive steps taken to safeguard financial stability, including developing facilities to inject capital and provide guarantees if needed. They called for continued vigilance in view of the challenging credit cycle underway. Vigilance will be particularly warranted with regard to exposures to commodity-affected sectors, non-banks such as insurers and pension plans, and highly indebted households, with a special focus on cross-institution spillovers. Looking further ahead, consolidation of securities regulation pursued by the government would further strengthen the framework for preserving financial stability.

Public Information Notices (PINs) form part of the IMF's efforts to promote transparency of the IMF's views and analysis of economic developments and policies. With the consent of the country (or countries) concerned, PINs are issued after Executive Board discussions of Article IV consultations with member countries, of its surveillance of developments at the regional level, of post-program monitoring, and of ex post assessments of member countries with longer-term program engagements. PINs are also issued after Executive Board discussions of general policy matters, unless otherwise decided by the Executive Board in a particular case. The staff report (use the free Adobe Acrobat Reader to view this pdf file) for the 2009Article IV Consultation with Canada is also available. 
Canada: Selected Economic Indicators 1/

(Annual change in percent, unless otherwise noted)

\begin{tabular}{|c|c|c|c|c|c|c|c|c|}
\hline & 2003 & 2004 & 2005 & 2006 & 2007 & 2008 & $\begin{array}{l}\text { Proj. } \\
2009 \\
\end{array}$ & $\begin{array}{l}\text { Proj. } \\
2010 \\
\end{array}$ \\
\hline Real GDP & 1.9 & 3.1 & 2.9 & 3.1 & 2.7 & 0.5 & -2.5 & 1.2 \\
\hline Net exports 2/ & -2.5 & -0.9 & -1.7 & -1.3 & -1.5 & -1.9 & 0.4 & -0.1 \\
\hline Total domestic demand & 4.6 & 4.2 & 4.8 & 4.7 & 4.3 & 2.4 & -3.2 & 1.3 \\
\hline Final domestic demand & 3.7 & 3.9 & 4.4 & 4.8 & 4.2 & 2.5 & -2.8 & 1.2 \\
\hline Private consumption & 3.0 & 3.3 & 3.7 & 4.3 & 4.5 & 3.0 & -2.3 & 0.7 \\
\hline Public consumption & 3.1 & 2.0 & 1.5 & 3.8 & 3.7 & 3.4 & 2.1 & 2.6 \\
\hline Private fixed domestic investment & 6.3 & 8.0 & 8.9 & 7.1 & 3.4 & 0.0 & -11.1 & -0.3 \\
\hline Private investment rate (as a percent of GDP) & 17.2 & 17.8 & 18.6 & 19.5 & 19.6 & 19.4 & 18.6 & 18.1 \\
\hline Public investment & 5.4 & 6.3 & 11.0 & 6.7 & 7.8 & 5.7 & 10.4 & 8.9 \\
\hline Change in business inventories $2 /$ & 0.8 & 0.1 & 0.3 & -0.1 & 0.1 & -0.1 & -0.4 & 0.0 \\
\hline GDP (current prices) & 5.2 & 6.4 & 6.3 & 5.7 & 5.9 & 4.4 & -3.9 & 2.5 \\
\hline \multicolumn{9}{|l|}{ Employment and inflation } \\
\hline Unemployment rate & 7.6 & 7.2 & 6.8 & 6.3 & 6.0 & 6.2 & 8.4 & 8.8 \\
\hline Consumer price index & 2.7 & 1.8 & 2.2 & 2.0 & 2.1 & 2.4 & 0.0 & 0.5 \\
\hline GDP deflator & 3.3 & 3.2 & 3.4 & 2.5 & 3.1 & 3.8 & -1.4 & 1.3 \\
\hline \multicolumn{9}{|l|}{ Exchange rate (period average) } \\
\hline U.S. cents/Canadian dollar & 0.72 & 0.77 & 0.83 & 0.88 & 0.94 & 0.94 & 0.80 & 0.79 \\
\hline Percent change & 12.3 & 7.6 & 7.2 & 6.8 & 6.1 & 0.8 & -15.3 & -1.2 \\
\hline Nominal effective exchange rate & 10.5 & 6.2 & 7.0 & 6.8 & 5.0 & -0.2 & $\ldots$ & $\ldots$ \\
\hline Real effective exchange rate & 11.1 & 5.5 & 6.1 & 5.9 & 4.4 & -1.6 & $\ldots$ & $\ldots$ \\
\hline \multicolumn{9}{|c|}{ Indicators of financial policies (national accounts basis, as a percent of GDP) } \\
\hline Federal fiscal balance & 0.3 & 0.8 & 0.1 & 0.7 & 1.0 & 0.2 & -2.0 & -2.4 \\
\hline Provincial fiscal balance $3 /$ & -1.2 & -0.7 & 0.6 & -0.2 & -0.3 & -0.4 & -1.8 & -1.5 \\
\hline General government & -0.1 & 0.9 & 1.5 & 1.3 & 1.4 & 0.4 & -3.4 & -3.6 \\
\hline Three-month treasury bill & 2.9 & 2.2 & 2.7 & 4.0 & 4.2 & 2.4 & 0.5 & 0.6 \\
\hline Ten-year government bond yield & 4.8 & 4.6 & 4.1 & 4.2 & 4.3 & 3.6 & 2.7 & 2.8 \\
\hline \multicolumn{9}{|l|}{ Balance of payments } \\
\hline Current account balance (as a percent of GDP) & 1.2 & 2.3 & 1.9 & 1.4 & 0.9 & 0.6 & -0.9 & -0.7 \\
\hline Merchandise trade balance (as a percent of GDP) & 4.6 & 5.1 & 4.5 & 3.4 & 3.1 & 2.9 & 1.1 & 1.5 \\
\hline Export volume & -2.1 & 5.2 & 2.0 & 0.9 & 1.4 & -5.0 & -14.5 & 0.6 \\
\hline Import volume & 3.1 & 8.5 & 7.6 & 5.0 & 5.4 & 1.0 & -16.0 & 1.3 \\
\hline Invisibles balance (as a percent of GDP) & -3.4 & -2.8 & -2.6 & -2.0 & -2.2 & -2.3 & -2.0 & -2.2 \\
\hline \multicolumn{9}{|l|}{ Saving and investment (as a percent of GDP) } \\
\hline Gross national saving & 21.2 & 23.0 & 23.9 & 24.3 & 24.1 & 23.7 & 21.6 & 21.6 \\
\hline General government & 2.3 & 3.5 & 4.4 & 4.3 & 4.5 & 3.7 & 0.5 & 0.6 \\
\hline Private & 18.9 & 19.6 & 19.5 & 20.0 & 19.7 & 20.0 & 21.1 & 21.1 \\
\hline Personal & 4.5 & 4.8 & 4.1 & 4.7 & 4.5 & 5.2 & 7.6 & 7.8 \\
\hline Business & 14.5 & 14.7 & 15.4 & 15.4 & 14.7 & 14.9 & 13.5 & 13.3 \\
\hline Gross domestic investment & 20.0 & 20.7 & 22.0 & 20.9 & 23.3 & 23.0 & 22.5 & 22.3 \\
\hline
\end{tabular}

Sources: Statistics Canada; and IMF staff estimates.

1/ Data as available on April 16, 2009.

2/ Contribution to growth.

$3 /$ Includes local governments and hospitals. 


\section{Statement by the IMF Staff Representative on Canada \\ May 11, 2009}

1. This statement reports on developments since the staff report was issued. They do not alter the thrust of the staff appraisal.

2. Recent indicators point to a continued, but moderating, contraction. Real GDP declined by 0.1 percent in February compared with an 0.7 percent fall in January, mostly reflecting lower production in good-producing industries, such as construction. The unemployment rate rose to 8 percent in March — a seven-year high — although the pace of job losses eased from February. The Bank of Canada's Spring Business Outlook Survey reported widespread expectations of slowing sales, but the balance of opinion was slightly less pessimistic than in the prior survey. Housing starts and sales recovered in March on low home prices and interest rates, albeit from weak levels, while non-residential construction declined. Headline inflation decelerated from 1.4 percent to 1.2 percent $(\mathrm{y} / \mathrm{y})$ in March, with core inflation registering 2 percent. Medium-term inflation expectations, as reflected in the April Consensus Economic survey, remain anchored to the Bank's 2-percent target.

3. On April 21, the Bank of Canada lowered its target for the overnight interest rate by 25 basis points to $1 / 4$ percent, and its April $23^{\text {rd }}$ Monetary Policy Report laid out a framework for conducting monetary policy at low interest rates. In conjunction with its rate cut, the Bank noted that the target rate could be expected to remain at its current level until the end of the second quarter of 2010, conditional on the inflation outlook. The Bank also lengthened its repo facilities to a maximum maturity of one year. The framework described less conventional tools, such as quantitative and credit easing, that could be deployed in future. It elaborated guiding principles for the conduct of policy, namely a focus on achieving the inflation target, maximum economic impact, neutrality across sectors and assets, and prudence with regard to risks to the Bank's balance sheet. The need for further measures would be assessed at each monetary policy meeting. The Bank lowered its projections for Canadian growth from -1.2 to -3 percent for 2009 and from 3.8 to 2.5 percent for 2010 , with risks to growth balanced and risks to inflation on the downside.

4. On the basis of recent data, staff has left the growth projection for 2009 broadly unchanged. Staff's growth projection for $2009\left(-2 \frac{1}{2}\right.$ percent, year-over-year) are between the latest Bank of Canada forecast (-3 percent) and the April consensus (-2.3 percent). Staff's projection for 2010 remains 1.2 percent, well below Bank of Canada and Consensus forecasts, mainly on expectations of a slower U.S. recovery.

5. Budget implementation is on track, with recent fiscal data more favorable than anticipated. Most of the funds for Budget 2009 have been appropriated and spending will come on stream this quarter, as planned. Data for the first 11 months of the fiscal year 2008/09 (i.e., April 2008 to February 2009) indicate a surplus of C\$1.3 billion (less than 
one-tenth of 1 percent of GDP), compared to a small deficit estimated in the January Budget, on stronger than expected personal and other income taxes.

6. Financial conditions remain more favorable than elsewhere, but credit conditions are still tight. Major Canadian banks have raised preferred shares in recent weeks, but have reported ongoing credit losses. The latest Bank of Canada Loan Officer Survey shows that the pricing and availability of business credit tightened further in 2009Q1, albeit at a slower pace than in 2008Q4. Credit spreads remain elevated, while stock prices have been volatile, echoing volatility in global equity and commodities markets. 
Table 1. Canada: Selected Economic Indicators (concluded)

\begin{tabular}{|c|c|c|c|c|c|c|c|c|c|}
\hline & \multirow[b]{2}{*}{2006} & \multirow[b]{2}{*}{2007} & \multirow[b]{2}{*}{2008} & \multicolumn{6}{|c|}{ Projections } \\
\hline & & & & 2009 & 2010 & 2011 & 2012 & 2013 & 2014 \\
\hline \multicolumn{10}{|l|}{ National Accounts in constant prices } \\
\hline Real GDP & 3.1 & 2.7 & 0.5 & -2.5 & 1.2 & 2.5 & 3.8 & 3.4 & 2.5 \\
\hline Q4/Q4 & 2.2 & 2.8 & -0.7 & -1.9 & 1.7 & 3.1 & 4.0 & 3.0 & 2.2 \\
\hline Net exports $1 /$ & -1.3 & -1.5 & -1.9 & 0.4 & -0.1 & 0.3 & 0.3 & 0.3 & 0.3 \\
\hline Total domestic demand & 4.7 & 4.3 & 2.4 & -3.2 & 1.3 & 2.2 & 3.6 & 3.1 & 2.2 \\
\hline Final domestic demand & 4.8 & 4.2 & 2.5 & -2.8 & 1.2 & 2.2 & 3.6 & 3.2 & 2.3 \\
\hline Private consumption & 4.3 & 4.5 & 3.0 & -2.3 & 0.7 & 2.4 & 3.8 & 3.3 & 2.0 \\
\hline Public consumption & 3.8 & 3.7 & 3.4 & 2.1 & 2.6 & 1.9 & 2.0 & 2.1 & 2.2 \\
\hline Private fixed domestic investment & 7.1 & 3.4 & 0.0 & -11.1 & -0.3 & 2.9 & 5.1 & 4.0 & 3.3 \\
\hline Machinery and equipment & 10.6 & 7.1 & 2.0 & -15.2 & 0.1 & 3.5 & 5.9 & 5.1 & 4.6 \\
\hline Residential construction & 2.2 & 3.0 & -2.9 & -15.0 & -1.2 & 2.5 & 4.4 & 3.3 & 2.3 \\
\hline Private investment (in percent of GDP) & 19.5 & 19.6 & 19.4 & 18.6 & 18.1 & 18.1 & 18.3 & 18.4 & 18.6 \\
\hline Public investment & 6.7 & 7.8 & 5.7 & 10.4 & 8.9 & -1.8 & 2.5 & 2.5 & 2.4 \\
\hline Change in inventories $1 /$ & -0.1 & 0.1 & -0.1 & -0.4 & 0.0 & 0.0 & 0.0 & 0.0 & 0.0 \\
\hline GDP (current prices) & 5.7 & 5.9 & 4.4 & -3.9 & 2.5 & 4.0 & 5.9 & 5.6 & 4.8 \\
\hline \multicolumn{10}{|l|}{ Employment and inflation } \\
\hline Unemployment rate (percent) & 6.3 & 6.0 & 6.2 & 8.4 & 8.8 & 8.0 & 6.3 & 6.2 & 6.1 \\
\hline Employment & 1.9 & 2.3 & 1.5 & -2.2 & 0.9 & 2.6 & 3.4 & 1.6 & 1.5 \\
\hline CPI inflation & 2.0 & 2.1 & 2.4 & 0.0 & 0.5 & 1.4 & 2.1 & 2.4 & 2.1 \\
\hline Core CPI inflation (y/y) & 1.9 & 2.1 & 1.7 & 1.3 & 0.4 & 0.8 & 1.7 & 2.2 & 2.0 \\
\hline GDP deflator & 2.5 & 3.1 & 3.8 & -1.4 & 1.3 & 1.5 & 2.0 & 2.2 & 2.3 \\
\hline Potential output growth & 2.3 & 2.3 & 2.2 & 1.7 & 1.6 & 1.6 & 1.7 & 1.9 & 2.0 \\
\hline Output gap (in percent of potential output) & 1.1 & 1.5 & -0.2 & -4.3 & -4.7 & -3.9 & -2.0 & -0.5 & 0.0 \\
\hline \multicolumn{10}{|l|}{$\begin{array}{l}\text { Indicators of fiscal policies } \\
\text { (NA basis, in percent of GDP) }\end{array}$} \\
\hline Federal fiscal balance & 0.7 & 1.0 & 0.2 & -2.0 & -2.4 & -1.6 & -0.9 & -0.5 & 0.0 \\
\hline Provincial fiscal balance $3 /$ & -0.2 & -0.3 & -0.4 & -1.8 & -1.5 & -1.1 & -0.6 & -0.2 & 0.2 \\
\hline General government fiscal balance 3/ & 1.3 & 1.4 & 0.4 & -3.4 & -3.6 & -2.3 & -1.2 & -0.4 & 0.4 \\
\hline General government net debt & 26.4 & 23.2 & 21.9 & 26.2 & 29.1 & 30.3 & 29.8 & 28.6 & 26.8 \\
\hline Three-month treasury bill (percent) & 4.0 & 4.2 & 2.4 & 0.5 & 0.6 & 2.6 & 4.3 & 4.8 & 4.8 \\
\hline Ten-year government bond yield (percent) & 4.2 & 4.3 & 3.6 & 2.7 & 2.8 & 4.2 & 5.2 & 5.5 & 5.5 \\
\hline \multicolumn{10}{|l|}{ External indicators } \\
\hline Current account balance (in percent of GDP) & 1.4 & 0.9 & 0.6 & -0.9 & -0.7 & -0.3 & 0.1 & 0.4 & 0.9 \\
\hline Merchandise trade balance (in percent of GDP) & 3.4 & 3.1 & 2.9 & 1.1 & 1.5 & 1.8 & 2.1 & 2.2 & 2.6 \\
\hline Export volume & 0.9 & 1.4 & -5.0 & -14.5 & 0.6 & 4.2 & 5.3 & 4.7 & 4.3 \\
\hline Import volume & 5.0 & 5.4 & 1.0 & -16.0 & 1.3 & 3.8 & 5.1 & 4.4 & 3.9 \\
\hline Balance on invisibles (in percent of GDP) & -2.0 & -2.2 & -2.3 & -2.0 & -2.2 & -2.1 & -1.9 & -1.8 & -1.7 \\
\hline Terms of trade & 0.6 & 3.0 & 4.7 & -7.6 & 1.9 & 0.5 & 0.3 & 0.1 & 0.9 \\
\hline \multicolumn{10}{|l|}{ Saving and investment (in percent of GDP) } \\
\hline Gross national saving & 24.3 & 24.1 & 23.7 & 21.6 & 21.6 & 21.9 & 22.4 & 22.8 & 23.4 \\
\hline General government & 4.3 & 4.5 & 3.7 & 0.5 & 0.6 & 1.7 & 2.7 & 3.6 & 4.4 \\
\hline Private & 20.0 & 19.7 & 20.0 & 21.1 & 21.1 & 20.1 & 19.6 & 19.2 & 19.0 \\
\hline Personal & 4.7 & 4.5 & 5.2 & 7.6 & 7.8 & 6.6 & 5.8 & 5.3 & 5.1 \\
\hline Business & 15.4 & 14.7 & 14.9 & 13.5 & 13.3 & 13.5 & 13.8 & 13.9 & 13.9 \\
\hline Gross domestic investment & 22.9 & 23.3 & 23.0 & 22.5 & 22.3 & 22.1 & 22.3 & 22.4 & 22.5 \\
\hline Personal Savings (in percent of DI) & 3.1 & 2.7 & 3.7 & 6.0 & 6.2 & 5.7 & 5.4 & 5.4 & 5.3 \\
\hline \multicolumn{10}{|l|}{ Memorandum item } \\
\hline Real GDP in United States & 2.8 & 2.0 & 1.1 & -2.8 & 0.0 & 3.6 & 3.7 & 3.3 & 2.4 \\
\hline
\end{tabular}

Sources: Haver Analytics; and Fund staff estimates.

$1 /$ Contribution to growth.

2/ Not seasonally adjusted.

$3 /$ Includes local governments and hospitals. 